UNIVERSIDADE DE SÃO PAULO

FACULDADE DE ECONOMIA, ADMINISTRAÇÃO E CONTABILIDADE DEPARTAMENTO DE CONTABILIDADE E ATUÁRIA PROGRAMA DE PÓS-GRADUAÇÃo EM CIÊNCIAS CONTÁBEIS

\author{
TRIBUTAÇÃO IMPLÍCITA: \\ REDUÇÃO DA TAXA DE RETORNO PRÉ-IMPOSTO \\ EM ATIVOS FAVORAVELMENTE TRIBUTADOS
}

Claudio Wasserman

Orientador: Prof. Dr. Eliseu Martins

SÃo PAULO 
Profa. Dra. Suely Vilela Reitora da Universidade de São Paulo

Prof. Dr. Carlos Roberto Azzoni

Diretor da Faculdade de Economia, Administração e Contabilidade

Prof. Dr. Fábio Frezatti

Chefe do Departamento de Controladoria e Contabilidade

Prof. Prof. Dr. Edgard Bruno Cornacchione Junior

Coordenador do Programa de Pós-Graduação em Controladoria e Contabilidade 


\title{
CLAUDIO WASSERMAN
}

TRIBUTAÇÃO IMPLÍCITA:

REDUÇÃO DA TAXA DE RETORNO PRÉ-IMPOSTO

EM ATIVOS FAVORAVELMENTE TRIBUTADOS

\begin{abstract}
Tese apresentada ao Departamento de Contabilidade e Atuária da Faculdade de Economia, Administração e Contabilidade da Universidade de São Paulo como requisito para obtenção do título de Doutor em Ciências Contábeis.
\end{abstract}

Orientador: Prof. Dr. Eliseu Martins

\section{SÃO PAULO}


Tese defendida e aprovada no Departamento de Contabilidade e Atuária da Faculdade de Economia, Administração e Contabilidade da Universidade de São Paulo - Programa de Pós-Graduação em Ciências Contábeis, pela seguinte banca examinadora:

Wasserman, Claudio

Tributação implícita: redução do retorno pré-imposto em ativos favoravelmente tributados / Claudio Wasserman.-- São Paulo, 2009.

$108 \mathrm{p}$.

Tese (Doutorado) - Universidade de São Paulo, 2009 Bibliografia

1. Contabilidade tributária 2. Benefício fiscal 3. Isenção de impostos I. Universidade de São Paulo. Faculdade de Economia, Administração e Contabilidade. II. Título.

$$
\text { CDD }-657.46
$$


Aos meus queridos pais, à minha eterna companheira, Ana, e ao meu filho amado, David. 
Sou especialmente grato à minha família. Aos meus pais, por todo o esforço e carinho. À minha esposa, pelo apoio e companheirismo. Ao meu filho, pela alegria de viver e por me dar um novo sentido à vida. À minha irmã, pelo coração repleto e aberto, conselhos e amizade. A todos, enfim, muito obrigado pelo amor incondicional.

Por tudo que já vi e ainda verei, duvido que encontre alguém da estatura moral, ética e profissional do Prof. Eliseu Martins. Ele me mostrou que é possível reunir, em um único ser humano, todas as qualificações necessárias para se tornar não apenas o melhor profissional da Contabilidade no Brasil mas uma verdadeira lenda na academia e fora dela. $O$ amálgama a unir as suas inúmeras qualidades profissionais são a humildade e a sua invulgar dimensão humana.

A todos os professores, em especial aos professores Nelson Carvalho, Alexsandro Broedel e Luiz Paulo Fávero. Ao Prof. Nelson pela forma como se põe diante da vida, a despeito de todas as enormes responsabilidades que sua competência lhe trouxe: sempre de bom humor, com dinamismo e carinho por todos que a ele recorrem. Ao Prof. Alexsandro, pelo exemplo vivo, inquietante e apaixonado do verdadeiro pesquisador. Ao Prof. Luiz Paulo, pelo acolhimento com que brinda os alunos, por ter me indicado o caminho metodológico a seguir e pela atitude séria e dedicada com que encara a vida acadêmica.

Aos meus eternos amigos Roberto Wainstok e Hélio Nigri. Sem a amizade deles, talvez até fosse possível terminar a tese, mas certamente a vida ficaria muito menos colorida. Obrigado a ambos pela convivência fraterna e pelo apoio nos momentos espinhosos.

Ao ex-delegado da Delegacia Especial de Assuntos Internacionais da Receita Federal Luiz Antonio Arthuso, que, por ser um entusiasta da contínua aprendizagem, me estimulou e ajudou nos momentos críticos. Também à Analidia Farias Peres, pela paciência e compreensão, e ao amigo de todas as horas Angelo Roncalli. Raymond Goldstein e José Henrique Pereira, a vocês também, grandes amigos, meu muito obrigado.

Ao pessoal da CETIP, em especial ao Jorge Sant'Anna e à Maria Lúcia, que sempre procuraram me ajudar nas minhas infindáveis demandas.

Àqueles que, com total desprendimento, apenas imbuídos da boa vontade de ajudar o próximo, sem nada esperar em troca, meu mais sincero agradecimento. Entre esses seres iluminados, Ricardo Alckmin Herrmann, do Tribunal de Contas da União, e Kátia Rocha, do IPEA. 


\section{RESUMO}

Tributos implícitos refletem a extensão pela qual ativos favorecidos tributariamente têm seu retorno pré-imposto reduzido em comparação com o retorno pré-imposto de ativos sem benefício fiscal e de risco similar. Em condição de equilíbrio de mercado, se dois ativos de riscos semelhantes possuírem o mesmo fluxo de caixa pré-imposto, mas um deles for favoravelmente tributado em relação ao outro, haverá maior demanda pelo ativo menos tributado, que terá, portanto, seu preço relativo aumentado. Conseqüentemente, dado que o retorno pós-imposto é o mesmo para ambos, o retorno pré-imposto do ativo favorecido será menor que o retorno pré-imposto do ativo não-beneficiado. A perda de retorno pré-imposto sofrida pelo ativo beneficiado decorre da tributação implícita. $\mathrm{O}$ aumento de preço do ativo beneficiado pressupõe que haja um detentor disposto a vendê-lo - um tipo de investidor para o qual a alteração nos preços relativos acontece sem que o seu retorno pós-imposto se altere: o investidor marginal. Investidores que possuam alíquota marginal de imposto explícita diferente da suportada pelo investidor marginal formam a denominada clientela tributária, que se constitui por um investidor para o qual a mudança nos preços relativos alteraria também o seu retorno pós-imposto. Os objetivos da tese são apresentar a teoria econômica e os conceitos subjacentes à tributação implícita, assim como comprová-la empiricamente. Trata-se de tema importante, pois traz à luz um tipo de tributação ainda pouco visível para a maioria dos indivíduos e das empresas, mas que é tão material quanto a explícita (descrita nos códigos e regulamentos tributários e provisionada nas demonstrações financeiras). A MP nº 281/2006, que introduziu a isenção de imposto de renda para os rendimentos produzidos por títulos públicos federais adquiridos por estrangeiros, foi o evento ao redor do qual se examinou o efeito causado pela isenção sobre os retornos da NTN-B, título escolhido pelos não-residentes à época do ato. A hipótese testada foi de que a entrada maciça do investidor estrangeiro reduziria significativamente o retorno pré-imposto do título. Para os testes, empregou-se a análise de séries temporais: o mesmo título foi utilizado antes (sem benefício fiscal) e depois (beneficiado quando adquirido por estrangeiros) da MP. Assim, a diferença de percepção de risco que investidores possuem ao carregar ativos diferentes ficou mitigada, o que permitiu que se isolasse o efeito do benefício tributário sobre os retornos. Os resultados confirmaram que o investidor estrangeiro sofreu uma significativa tributação implícita: a depender da série da NTN-B, o investidor estrangeiro foi tributado implicitamente de $11 \%$ a $13 \%$. A pesquisa contém também uma outra situação relacionada à MP $n^{\circ} 281 / 2006$, mas que decorreu de falta de liquidez da NTN-B, quando o estrangeiro quis sair do mercado em momento posterior à entrada em vigor da MP. Nesse segundo instante, comprovou-se que o investidor estrangeiro recebeu um tributo implícito pago pelo governo brasileiro. Procurou-se demonstrar que o tributo implícito não é tipicamente pago para as autoridades tributárias. $\mathrm{Na}$ entrada do estrangeiro, houve pagamento de tributo implícito do não-residente para o investidor nacional. No momento seguinte, quando o investidor estrangeiro desejou sair do papel, o governo pagou o imposto implícito recebido pelo não-residente. Esses resultados contribuem para a pesquisa tributária no Brasil ao trazer novos conceitos correlatos à tributação implícita e demonstrar empiricamente que alterações tributárias podem resultar em alteração no retorno pré-imposto de ativos. Por exemplo, decisões de investidores podem ser afetadas quando uma empresa que tradicionalmente pagava dividendos passa a distribuir o seu lucro na forma de juros sobre capital próprio, conforme prediz a teoria da clientela tributária. Os resultados e conceitos também podem auxiliar na análise das conseqüências, sobre a economia como um todo, da implantação de políticas tributárias, assim como na implementação específica de determinado incentivo tributário sobre o retorno pré-imposto dos mais variados tipos de ativo. 


\begin{abstract}
Implicit taxes reflect the extent to which tax-favored assets bear lower pre-tax returns than do tax-disfavored assets of similar risk. In equilibrium, when two assets give rise to identical pre-tax cash flows, but the cash flows from one asset are taxed more favorably than those from the other asset, the tax-favored asset will increase relative to the price of the taxdisfavored asset. Consequently, given that the after-tax returns are the same to both assets, the pre-tax rate of return to the tax-favored asset will fall below that for the tax-disfavored asset. The loss of pre-tax return bore by the tax-favored asset is due to the implicit tax. The price rise of the tax-favored asset indicates that there is an investor willing to sell it -a kind of investor to whom the prices of the assets change, with the result that the after-tax rates of return will remain the same to them (the marginal investor). Investors with explicit tax rates different from the explicit tax rate faced by marginal investors form a group of investors known as tax clientele. Those investors (clientele) are not indifferent to assets differently taxed. This research aims to present the economic theory and the main concepts related to implicit taxes, and still to test empirically its existence. Implicit taxes are an important issue because it sheds light upon a kind of taxation practically invisible to most people and businesses, but yet as real as the explicit taxes. The Provisional Measure n. 281/2006, which provided income tax exemption to non-resident investors who acquired federal government bonds, was the event chosen to empirically test for implicit tax effects, by examining NTN-B return changes surrounding the act. Indications suggested that foreign investors focused on a long-term Brazilian bond called NTN-B. The hypothesis to be tested was that the massive entrance of foreign investors would significantly reduce the NTN-B pre-tax return. Time series analysis was employed: the same bond was used before (without the tax exemption) and after (with the tax exemption) the act. Therefore, this study is less subject to confounding cross-sectional risk differences, helping to distinguish between the effects of taxes and risk. Results of empirical tests report a significant decrease of return suffered by the foreign investor, from $11 \%$ to $13 \%$, depending on the bond invested. The study also investigates another event related to the tax exemption, but actually connected to the small liquidity of the $N T N-B$. Few months later, the same foreign investor who massively bought the NTN-B in response to the tax exemption decided to leave the Brazilian market. At this time, the Brazilian government paid him a significant implicit tax. The comparison between the first event (tax exemption) and the second one (liquidity) shows that implicit taxes are typically not paid directly to the taxing authority. When the foreign investor first entered the market, he paid implicit taxes to the Brazilian investor. Later on, when the foreign investor decided to sell the bond recently bought, the Brazilian government then paid him implicit taxes. These results contribute to tax research by demonstrating that changes in tax rates may result in changes in pre-tax returns. For instance, according to the theory of tax clienteles, the decisions of investors might be affected when a Brazilian company decides to change its dividend policy, by paying interest on own equity instead of dividends. The results and concepts also provide information to tax policy makers on the economy-wide effects of tax rate changes, as well as the effects of specific tax incentives on pre-tax returns.
\end{abstract}




\section{SUMÁRIO}

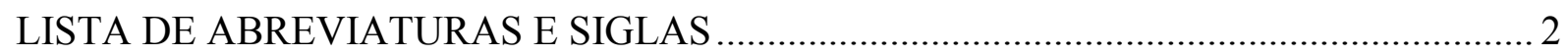

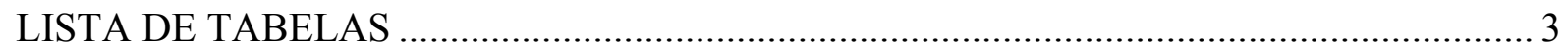

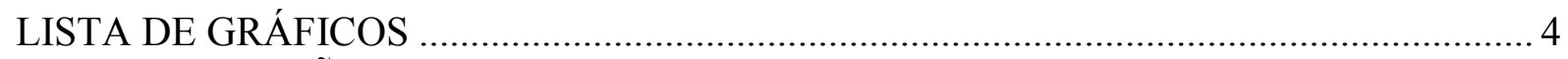

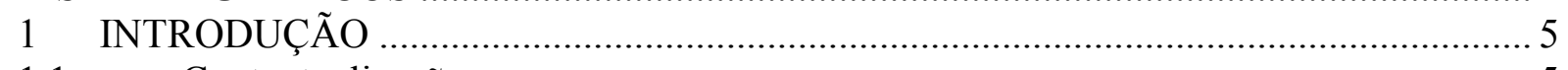

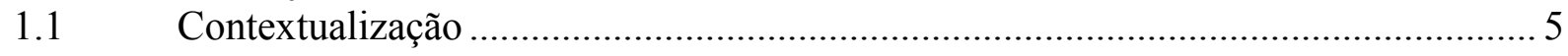

1.2 Caso Compaq: desconsideração da tributação implícita nas Cortes Americanas .... 14

1.3 A perspectiva contratual e a tributação implícita ..................................................... 18

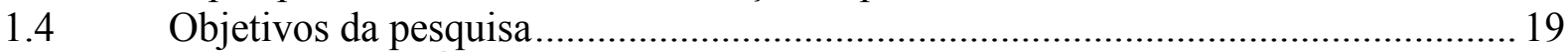

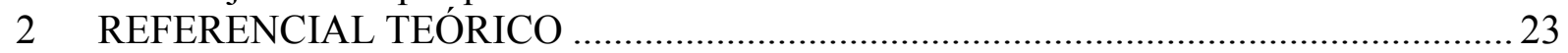

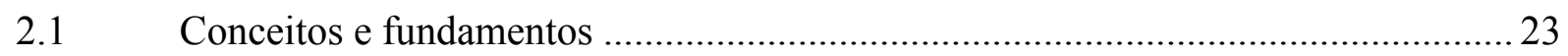

2.1.1 Fundamentação econômica da tributação implícita .................................................2 23

2.1.2 Investidor marginal e clientela tributária ……………………………………....2. 25

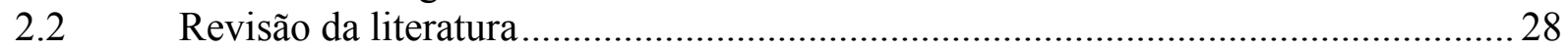

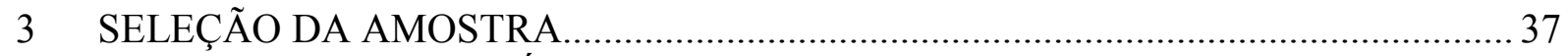

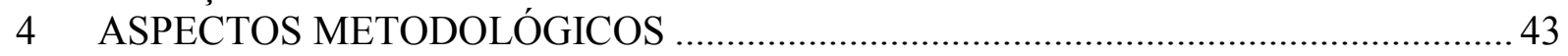

4.1 Metodologia de Precificação de Títulos Públicos ....................................................... 45

4.1.1 Histórico e procedimentos sobre a precificação dos títulos públicos......................... 46

4.1.2 Metodologia de cálculo das taxas de retorno …………………………………..... 47

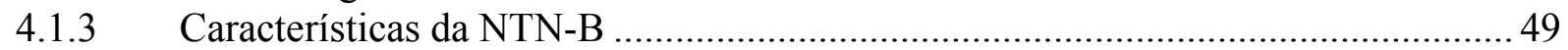

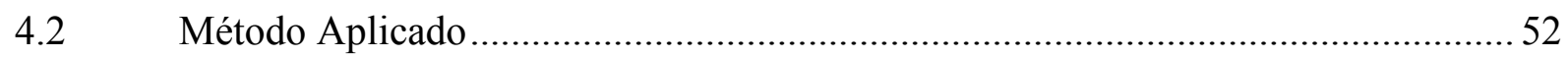

4.2.1 Método de Box-Jenkins............................................................................... 52

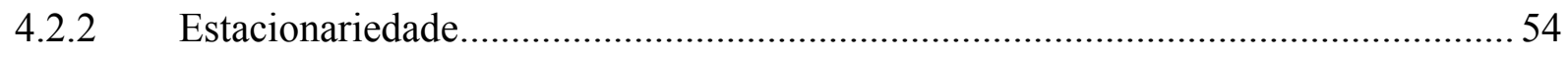

4.2.3 Modelos de séries de tempo ……………………........................................5

4.2.4 Análise de intervenção ……………………………………………………....57

4.2.5 Passos para a construção de um modelo ARIMA …………………………………... 60

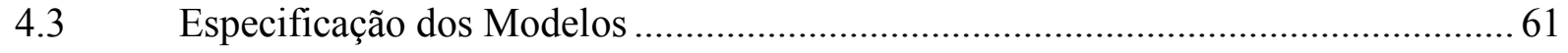

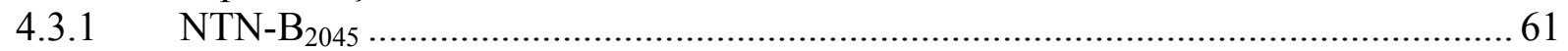

4.3.1.1 Identificação do modelo ................................................................................... 61

4.3.1.2 Estimação do modelo ................................................................................. 74

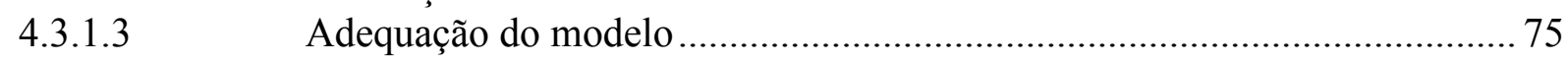

4.3.1.4 Análise dos resultados ..................................................................... 77

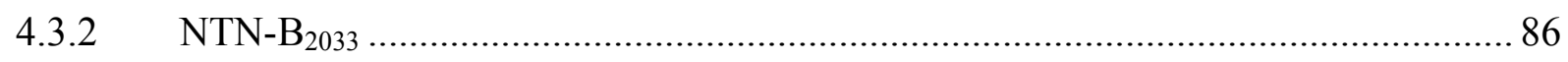

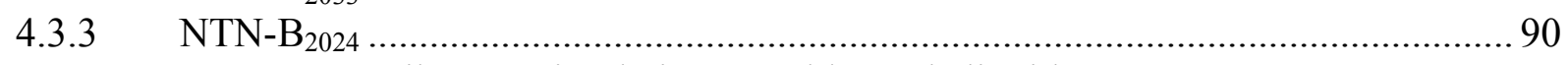

4.4 Outra vez a tributação implícita: o problema da liquidez ......................................... 93

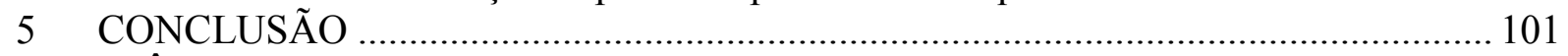

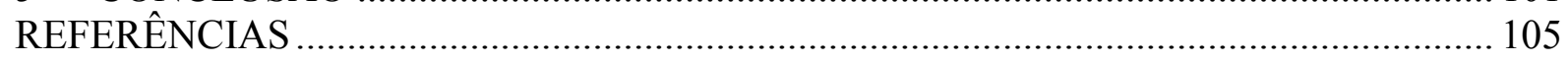




\section{LISTA DE ABREVIATURAS E SIGLAS}

ADF - Augmented Dickey-Fuller

ADR - American Depositary Receipts

AMTBIA - alternative minimum tax book income adjustment

ANDIMA - Associação Nacional das Instituições do Mercado Financeiro

AR - modelo auto-regressivo

ARIMA - modelo auto-regressivo (AR), $\mathrm{n}^{\circ}$ de integrações I e de médias móveis (MA)

ARMA - modelo auto-regressivo (AR) e de médias móveis (MA)

CAPM - capital asset pricing model

COFINS - Contribuição para o Financiamento da Seguridade Social

DPMFi - dívida pública mobiliária federal interna

$\mathrm{DRD}$ - dividends received deduction

EMBI+ - Emerging Markets Bond Index Plus

EMBIG - Emerging Markets Bond Index Global

FAC - funções de autocorrelação

FACP - funções de autocorrelação parcial

ICMS - Imposto sobre Circulação de Mercadorias e Serviços

IPCA - Índice Nacional de Preços ao Consumidor Amplo

IPEA - Instituto de Pesquisa Econômica Aplicada

IPI - Imposto sobre Produtos Industrializados

IRS - Internal Revenue Service

LFT - Letras Financeiras do Tesouro

LTN - Letras do Tesouro Nacional

MA - modelo de médias móveis

MP - medida provisória

MTR - marginal tax rate

NTN-B - Nota do Tesouro Nacional - série B

NTN-C - Nota do Tesouro Nacional - série C

PIS - Programa de Integração Social

PP - Phillips-Perron

SELIC - Serviço Especial de Liquidação e Custódia

STN - Secretaria do Tesouro Nacional

VNA - valor nominal atualizado

YTM - yield to maturity 


\section{LISTA DE TABELAS}

Tabela 1 - resultado pretendido pela Compaq na operação de dividend-stripping 15

Tabela 2 - resultado da operação, baseado no pre-tax profit, de acordo com o IRS e a primeira instância do Judiciário norte-americano (depois de pago o imposto na Holanda, mas antes do imposto pago nos EUA) ..................................................... 16

Tabela 3 - "pre-tax profit test" aplicado pela segunda instância americana.............................. 16

Tabela 4 - cômputo do resultado da operação da Compaq antes dos impostos implícitos e explícitos

Tabela 5 - composição percentual da DPMFi, por títulos sob responsabilidade da Secretaria do Tesouro Nacional, ano 2006.

Tabela 6 - testes ADF e PP de raiz unitária para a série diferenciada dos retornos da NTN$\mathrm{B}_{2045}$

Tabela 7 - testes ADF e PP de raiz unitária relativos à série de primeiras diferenças dos retornos NTN-B $2045(3 / 1 / 2005$ a $9 / 2 / 2006)$.

Tabela 8 - Teste de Dickey e Pantula para $\mathrm{H}_{0}{ }^{3}: \mathrm{d}=3$ (três raízes unitárias) e $\mathrm{H}_{1}{ }^{3}: \mathrm{d}=2 \ldots \ldots 66$

Tabela 9 - Teste de Dickey e Pantula para $\mathrm{H}_{0}{ }^{2}: \mathrm{d}=2$ (duas raízes unitárias) e $\mathrm{H}_{1}{ }^{2}: \mathrm{d}=1 \ldots \ldots 66$

Tabela 10 - Teste de Dickey e Pantula para $\mathrm{H}_{0}{ }^{1}: \mathrm{d}=1$ (uma raíz unitária) e $\mathrm{H}_{1}{ }^{1}: \mathrm{d}=0 \ldots \ldots \ldots 6$

Tabela 11 - parâmetros estimados do modelo $\left(Z_{t}=\omega S_{t}^{T}+\varepsilon_{t}\right)$ de retornos da NTN-B 2045

$(3 / 1 / 2005$ a $3 / 3 / 2006)$.

Tabela 12 - teste de igualdade de média das duas subamostras dos retornos díários da

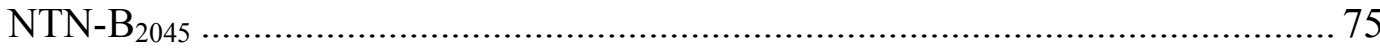

Tabela 13 - teste de igualdade de variância das duas subamostras dos retornos díários da NTN-B 2045 76

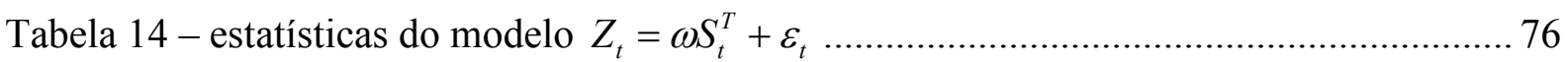

Tabela 15 - Outliers level shift detectados nos EMBI+ de janeiro a março de 2006 ............. 85

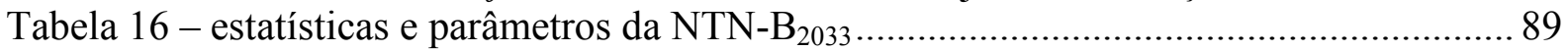

Tabela 17 - estatísticas e parâmetros do modelo estimado para a NTN-B 2024 …................... 92

Tabela 18 - estimativas do modelo que inclui os dois eventos: MP $\mathrm{n}^{\circ} 281 / 06$ e liquidez........ 98 


\section{LISTA DE GRÁFICOS}

Gráfico 1 - curvas de demanda e oferta por títulos brasileiros ............................................ 23

Gráfico 2 - aumento demanda estrangeira por títulos brasileiros .......................................... 25

Gráfico 3 - comportamento das séries diárias dos retornos das NTN-B ${ }_{2045}, \mathrm{NTN}_{-} \mathrm{B}_{2033} \mathrm{e}$

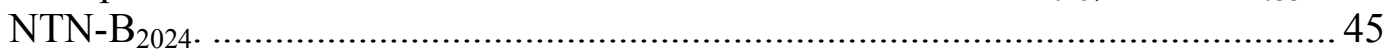

Gráfico 4 - série de retornos diários da NTN-B ${ }_{2045}$ de 16/09/2004 a 28/02/2008 ................... 61

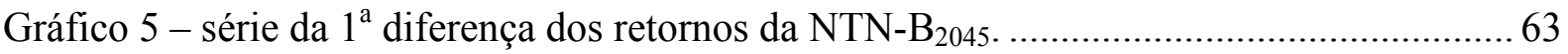

Gráfico 6 - série diária de retornos original da NTN-B ${ }_{2045}$ de 3/1/05 a 9/2/06 ...................... 64

Gráfico 7 - primeiras diferenças dos retornos diários NTN-B2045 de 3/1/2005 a 9/2/2006 .. 64

Gráfico 8 - retornos da NTN-B 2045 , de janeiro de 2006 a meados de fevereiro de $2006 \ldots \ldots . . .71$

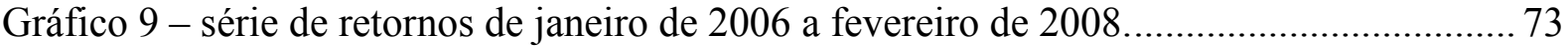

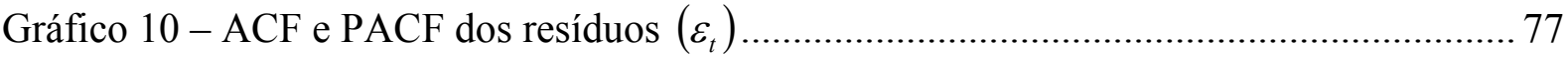

Gráfico 11 - Relação entre EMBI-Brasil e EMBI-México, de janeiro a março de 2006. ....... 79

Gráfico 12 - relação entre EMBI-Brasil e EMBI-Rússia, de janeiro a março de 2006.......... 79

Gráfico 13 - relação entre EMBI-Brasil e EMBI-Turquia, de janeiro a março de 2006 ......... 80

Gráfico 14 - relação entre EMBI-Brasil e EMBI-Venezuela, de janeiro a março de 2006 .... 80

Gráfico 15 - relação entre EMBI-Brasil e EMBI-Filipinas, de janeiro a março de 2006 ........ 81

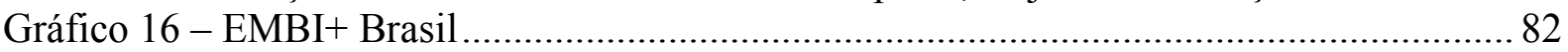

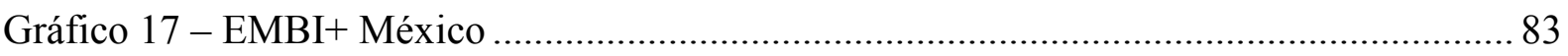

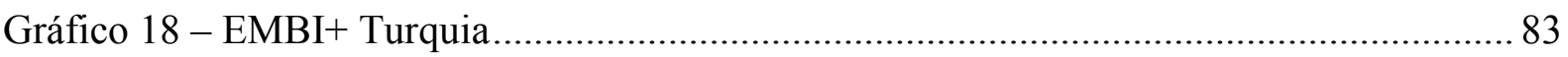

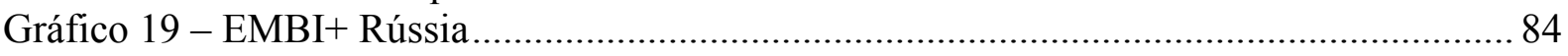

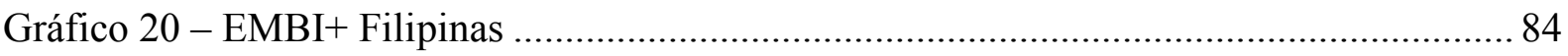

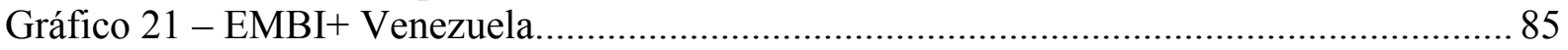

Gráfico 22 - série de retornos diários da NTN-B 2033 de 2/1/2004 a 28/2/2008 ...................... 87

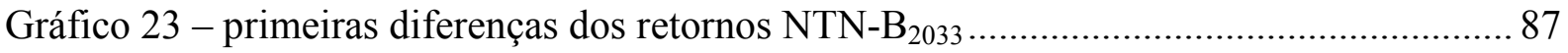

Gráfico 24 - primeiras diferenças retornos NTN-B 2033 , período de 3/1/2005 a 10/2/2006 .... 88

Gráfico 25 - retornos da NTN-B ${ }_{2033}$, de janeiro de 2006 a meados de fevereiro de $2006 \ldots . . .88$

Gráfico 26 - retornos diários NTN-B 2024 no período de 2/1/2004 a 28/2/2008 ...................... 90

Gráfico 27 - primeiras diferenças NTN-B 2024 (2/1/2004 a 28/2/2008) .................................. 91

Gráfico 28 - retornos diários de NTN-B 2024 (2/1/2006 a 15/03/2006) ................................... 91

Gráfico 29 - retornos NTN-B 2045 do final da intervenção causada pela MP no 281/2006 até

o leilão empreendido pelo governo para dar liquidez às NTN-B ........................ 95

Gráfico 30 - retornos NTN-B 2045 após leilão realizado em 24/5/2006 …............................... 95 


\section{INTRODUÇÃO}

\subsection{Contextualização}

Modigliani e Miller (1958) demonstraram que, sob a hipótese de mercados perfeitos, a decisão quanto à forma de financiamento seria irrelevante no processo de criação de valor das empresas. Suas conclusões seriam válidas desde que presente o pressuposto de que os mercados de capitais fossem perfeitos, ou seja, de que os mercados funcionassem sem a incidência de tributos e inexistissem custos de transação. Nas últimas décadas, todavia, um grande número de pesquisas passou a adotar a hipótese de mercados imperfeitos, em face de custos crescentes (fricções) para a obtenção de informações e da presença cada vez mais expressiva da tributação na vida de empresas e pessoas.

O marco na pesquisa tributária em Contabilidade foi o trabalho de Myron S. Scholes, professor de Finanças e prêmio Nobel pelo desenvolvimento de um modelo de precifícação de opções, e Mark A. Wolfson, professor de Contabilidade. Eles trouxeram para a pesquisa tributária contábil uma visão microeconômica e de finanças que tornou o seu Taxes and Business Strategy: A Planning Approach ${ }^{1}$ (1982) a gênese da grande maioria dos estudos tributários de primeira linha (SHACKELFORD; SHEVLIN, 2001, p. 324).

O paradigma de Scholes-Wolfson não apresenta novas teorias ou metodologias, tampouco se detém em detalhes legais, regulamentares ou de política tributária. Eles adotam uma abordagem cientificamente positiva, por meio da qual tentam explicar empiricamente o papel dos tributos nas organizações empresariais e na vida dos indivíduos, aliando Contabilidade, Microeconomia, Finanças e legislação tributária.

O pilar conceitual de Scholes-Wolfson repousa sobre três temas centrais conhecidos como "todas as partes, todos os tributos e todos os custos", os quais, tomados em conjunto, ensinam que, para ser efetivo, um planejamento tributário deve: (i) considerar, para todas as partes envolvidas, as conseqüências tributárias de uma transação; (ii) levar em consideração, nas

\footnotetext{
${ }^{1} \mathrm{O}$ artigo de Scholes e Wolfson foi a semente para o livro Taxes and Business Strategy - A Planning Approach, que tem como co-autores Merle Erickson, Edward L. Maydew e Terry Shevlin.
} 
decisões de investimento e financiamento, não apenas a tributação explícita (pagamento de tributos feito diretamente às autoridades tributárias), mas também a tributação implícita (tributos pagos indiretamente na forma de uma taxa de retorno mais baixa antes do imposto, obtida em investimentos/ativos tributados mais favoravelmente); e (iii) reconhecer que os tributos representam apenas um entre muitos outros custos, e que todos os custos (tributários e não-tributários) devem ser considerados no planejamento, não sendo a minimização do pagamento tributário necessariamente a solução mais indicada em todos os casos.

Mesmo admitindo que decisões corporativas possuem múltiplas facetas além da tributária, é imprescindível o dimensionamento correto do pagamento de tributos, sob pena de se comprometer o bom andamento dos negócios ou das operações em jogo. Nesse sentido, o entendimento da tributação implícita é uma vantagem competitiva considerável, principalmente porque detectá-la ainda é tarefa para poucos. Entendê-la pode ser a diferença entre decidir corretamente ou não quanto à melhor forma de investimento ou financiamento; pode também determinar o maior ou o menor sucesso na implantação de políticas públicas; e ainda, se não levada em consideração a tributação implícita, podem ficar prejudicadas até mesmo decisões judiciais, como o caso da Compaq nos EUA, descrito adiante.

Tributos implícitos revelam a extensão (se houver) pela qual ativos favorecidos tributariamente produzem menor retorno antes dos impostos ${ }^{2}$ do que o retorno obtido por ativos menos favorecidos tributariamente, tendo em conta que os riscos envolvidos são similares (ERICKSON; MAYDEW, 1998, p.435).

O mecanismo da tributação implícita será mais bem explorado adiante, mas, preliminarmente, pode-se adiantar que os tributos implícitos surgem porque, quando dois ativos geram idênticos fluxos de caixa antes dos impostos, mas o fluxo de caixa de um é tributado mais favoravelmente que o fluxo do outro ativo, haverá uma demanda mais elevada pelo ativo mais favoravelmente tributado. Como resultado, o preço do ativo de tratamento tributário mais favorável subirá em relação ao ativo cuja tributação é desfavorecida. E, porque os fluxos de caixa dos dois ativos são idênticos, a taxa de retorno antes dos impostos do ativo

\footnotetext{
${ }^{2}$ A expressão "retorno antes dos impostos" refere-se, no caso do Brasil, ao retorno antes do imposto de renda e da contribuição social sobre o lucro líquido. Por simplificação, daqui por diante as expressões "imposto de renda" e "imposto" devem ser compreendidas, no contexto brasileiro, como a tributação conjunta do imposto de renda e da contribuição social. Isso posto, define-se retorno de um ativo como o quociente entre o lucro préimposto gerado por ele e o seu preço. Por ser especialmente importante para a presente pesquisa, o retorno de um um título público é dado pela a razão entre o rendimento produzido por ele e o seu preço.
} 
favoravelmente tributado será inferior à do ativo mais pesadamente tributado. A perda do retorno experimentada pelo ativo de tratamento tributário mais benéfico é o que se convencionou chamar de tributação implícita. Em casos particularmente importantes, quando presentes investidores com características especiais - os investidores marginais, vistos em mais detalhes na subseção 2.1.2 -, a alteração nos preços relativos acontece sem que o seu retorno pós-imposto se altere. É a equalização dos retornos após os impostos, uma condição necessária para o equilíbrio de mercado ${ }^{3}$.

Já é possível vislumbrar, portanto, que, além da hipótese de equilíbrio de mercado, o cálculo do imposto implícito requer um ativo referência (benchmark) a partir do qual se comparam as taxas de retorno antes do imposto dos demais ativos de risco equivalente. $\mathrm{O}$ ativo referência deve ser tributado sem qualquer favorecimento tributário - não há diferimento tributário nos ganhos econômicos auferidos por esse benchmark. Um título integralmente tributado e livre de risco, cuja taxa de juros seja determinada pelo mercado, pode ser tido como um ativo referência. Além disso, não há mudanças econômicas no valor desse ativo que possam ser postas em dúvida. Assim, os ativos que forem menos tributados que o ativo referência são tidos como ativos favoravelmente tributados; já os ativos mais tributados que o benchmark serão considerados como ativos desfavoravelmente tributados (SCHOLES et al, 2005, p. 120).

São várias as formas de favorecimento tributário: imunidade tributária (templos, instituições de educação, livros, jornais, periódicos, entre outros expressos taxativamente no art. 150, VI, da Constituição da República Federativa do Brasil); isenções de ICMS para implantação de fábricas; créditos de IPI para receitas de exportação; incentivos fiscais setoriais (agronegócios, bens de capital, têxtil, software etc.); dedutibilidade tributária mais rápida do que o declínio econômico do ativo (depreciação acelerada, imediata descarga como despesa de gastos com pesquisa e desenvolvimento etc.); diferimento de lucro (reconhecimento do lucro tributário feito posteriormente ao reconhecimento do lucro contábil, como no caso de contratos de longo prazo realizados com entidades governamentais), isenção tributária de rendimentos auferidos por aplicações lastreadas em títulos públicos, entre outros exemplos existentes nas três esferas governamentais.

\footnotetext{
${ }^{3}$ Scholes et al (op. cit., p. 119) ensinam que as fricções de mercado e as restrições impostas pelas regras tributárias são as forças que previnem a arbitragem tributária.
} 
Há, por outro lado, tratamentos tributários desfavoráveis, tais como dedutibilidade fiscal mais lenta que o declínio econômico do valor do ativo (amortização fiscal do ativo diferido em prazo mínimo de 5 anos, ainda que economicamente esse ativo não contribua com resultados futuros da entidade); reconhecimento do lucro tributável mais rapidamente que o lucro contábil (vedação de dedutibilidade da provisão para créditos de difícil liquidação, admitida tão-somente a perda efetiva no recebimento de créditos); tratamento desvantajoso em função de características tributárias e econômicas (não-cumulatividade de PIS/COFINS para certos setores, mas não admitida para outros), além de outras condições estipuladas nas legislações referentes aos mais diversos tributos.

Scholes et al (op. cit., p. 121) apresentam o caso norte-americano dos títulos municipais versus títulos de igual risco integralmente tributados. Títulos municipais (também conhecidos como munies, de municipal bonds) são usualmente isentos de imposto de renda nos EUA. São, por isso, relativamente aos títulos federais, mais demandados por investidores, o que causa aumento do preço dos títulos municipais. No caso do aumento de demanda pelos títulos municipais em relação aos federais, os preços dos munies aumentarão, reduzindo-se, pois, o seu retorno pré-imposto (basta lembrar que retorno é a relação entre o rendimento do título (que não se alterou) e o seu preço (que aumentou), v. nota 2).

Posto isso, pode-se agora utilizar um exemplo, extraído de Scholes et al (op. cit., p. 125-127), em que se ilustra o funcionamento da incidência implícita de tributo. Suponha-se que o retorno antes do imposto dos títulos sem tributação favorecida (por hipótese, um título emitido pelo governo federal) seja $10 \%$ e que o retorno pré-imposto de títulos municipais, isentos de tributação, seja de 7\%. A diferença dos retornos decorre da maior demanda pelos títulos municipais (pressupõe-se que títulos federais e municipais tenham riscos semelhantes), que, por isso, têm seus preços aumentados em relação aos títulos cuja tributação é menos favorável, lembrando que, em equilíbrio, os dois ativos possuem igual retorno após os impostos.

Tributo implícito é aquele que, se incidisse explicitamente a uma alíquota determinada, $\tau_{\text {implicita }}$, sobre o retorno antes do imposto de um investimento sem favorecimento tributário, $b$ (benchmark), levaria ao mesmo retorno propiciado pelo investimento favorecido tributariamente, $a$ (alternativo), como expresso abaixo. 


$$
R_{b}\left(1-\tau_{\text {implicita }}\right)=R_{a} \leftrightarrow \tau_{\text {implicita }}=\left(R_{b}-R_{a}\right) / R_{b}
$$

Equação 1 - expressão matemática do tributo implícito

Onde $R_{b}$ é o retorno pré-imposto de um ativo tributado sem benefícios fiscais (benchmark); $R_{a}$ é o retorno pré-imposto de um ativo tributado favoravelmente, e $\tau_{\text {implicita }}$ é a alíquota do tributo implícito.

Aplicando-se a Equação 1, se um título sem benefício fiscal tiver um retorno de $10 \%$ antes do imposto e o bond municipal retornar 7\% (antes e depois do imposto, já que é, por hipótese, isento), a alíquota do tributo implícito incidente sobre o título municipal será de $30 \%$ ([10\%7\%]/10\%). Apesar de investidores não pagarem qualquer tributo explicitamente sobre os retornos proporcionados pelos títulos municipais, eles pagam tributos implicitamente a uma alíquota de 30\% na forma de um retorno antes do imposto mais reduzido. As municipalidades recebem um subsídio implícito, via custo de capital mais baixo. Esse subsídio implícito recebido pelas municipalidades teria o mesmo resultado se todos os títulos (municipais e federais, no exemplo acima) fossem tributados à alíquota federal, portanto sem qualquer benefício, e o governo federal repassasse a parte da arrecadação referente aos bonds municipais para as administrações locais. Por essa alternativa, o retorno antes dos impostos dos títulos municipais e dos títulos federais seria de 10\%. Para os investidores, seria indiferente se o título fosse municipal ou federal, pois o retorno antes do imposto para ambos seria o mesmo.

No exemplo acima, a isenção tributária concedida a títulos municipais resultou num pagamento de imposto explícito de $0 \%$, mas os investidores pagaram implicitamente $30 \%$ do seu retorno antes dos impostos, o que equivale a dizer que os municípios emitiram seus títulos a um custo mais reduzido que os títulos federais. É interessante mostrar, adicionalmente, como outros mecanismos de favorecimento tributário dão margem ao surgimento de tributos implícitos, não necessariamente pagos a governos.

No Brasil, como em outros países, existe a figura da depreciação acelerada incentivada. Ativos adquiridos em certa época ou para integrar programas de estímulos industriais ou setoriais podem ser depreciados a uma velocidade superior à velocidade de ativos idênticos adquiridos fora daquelas condições. Supondo-se, por exemplo, a aquisição de um equipamento pelo custo de $\$ 100.000$ e que a empresa tenha uma alíquota de imposto 
marginal $^{4}$ (marginal tax rate) de 40\%, uma dedução imediata do custo de aquisição reduziria o imposto em $\$ 40.000$ (\$100.000 x 40\%). Com uma taxa de depreciação mais lenta, o valor presente do benefício fiscal da depreciação reduz-se (mantida a taxa de desconto). E, quanto menos favorecido tributariamente, menor o valor do ativo. Admita-se um prazo de depreciação de 2 anos, pelo método da linda reta, e uma taxa de desconto de $9 \%$. Dessa forma, o benefício fiscal trazido a valor presente decorrente das despesas de depreciação é dado por $\{(\$ 50.000 \times 0,40)+(\$ 50.000 \times 0,40 / 1,09)=\$ 38.349\}$.

Vê-se que o benefício fiscal da depreciação seria $\$ 1.651$ inferior à dedução integral e imediata do custo de aquisição (\$40.000). Se o ativo fosse depreciado em 4 anos à mesma taxa de desconto, o benefício físcal se reduziria em $\$ 4.687$ quando comparado ao benefício propiciado pela imediata recuperação do investimento.

O aumento do prazo (ou a diminuição da velocidade da depreciação) tem o mesmo efeito que um aumento da taxa de desconto. Logicamente, o resultado da aceleração da depreciação é o mesmo que o de uma redução da alíquota de imposto marginal. Ao longo do tempo, a conseqüência de um decréscimo da alíquota de imposto marginal pode ser visualizada pela relação entre o rendimento, líquido do imposto, de uma aplicação de \$1 e o investimento de $\$ 1$, também líquido do imposto, supondo, por simplicidade, que esse investimento tem seus rendimentos tributados depois de $n$ períodos, após os quais ele gera $\$(1+R)^{\mathrm{n}}$ (ou seja, a taxa de retorno antes do imposto é $R$ ), e que o custo desse investimento é imediatamente descarregado (depreciação acelerada ao máximo) como despesa no período de aquisição do investimento:

$$
\text { Retorno após impostos }=\frac{\$ 1(1+R)^{n}\left(1-\tau_{n}\right)}{\$ 1\left(1-\tau_{0}\right)}
$$

Equação 2- relação entre rendimento e investimento

\footnotetext{
${ }^{4}$ Muitos pesquisadores utilizam a MTR, marginal tax rate, para captar a dinâmica das regras tributárias. A MTR pode ser definida como o valor presente do imposto incremental pago sobre uma unidade monetária adicional de lucro tributável corrente (GRAHAM, 2007, p.2 e SCHOLES et al, op. cit., p.186). Shevlin (1990) e Graham (1996) simulam a MTR ao incluir no seu cálculo prejuízos fiscais (net operating loss), que podem ser utilizados nos EUA para restituir imposto já pago ou para compensar, em até um certo número de anos, lucro tributável futuro. No Brasil, os prejuízos físcais correntes só podem ser utilizados para compensar lucro tributável futuro, sem limite de prazo para utilizá-los, mas com a restrição de que só podem compensar até 30\% do lucro tributável. No cálculo da MTR, para captar a realidade tributária de cada empresa, devem ser incluídos, além do prejuízo fiscal, qualquer outra possibilidade da realidade tributária futura que possa ser captada no período corrente, como créditos tributários, perspectivas de mudança nas regras tributárias etc. A MTR é uma proxy bastante utilizada em estudos que procuram comprovar a influência da tributação nas decisões corporativas. Para uma visão ampla das possibilidades de sua utilização, consultar Taxes and Corporate Finance, de Graham (2003).
} 
Onde $R$ é o retorno pré-imposto, $\tau_{n}$ é a alíquota marginal do imposto no período $n$ e $\tau_{0}$ é a alíquota marginal de imposto no período de aquisição do investimento.

A Equação 2 evidencia que existe uma relação de forças entre investidor e governo. $\mathrm{O}$ investidor põe uma fração $\left(1-\tau_{0}\right)$ do seu capital em troca da parte que cabe ao governo $\left(1-\tau_{n}\right)$. Assim, se a alíquota marginal no período corrente for igual à do período futuro, dizse que o retorno do investimento é isento de tributação. Dizer que o retorno obtido por um investimento é isento significa que o seu retorno antes do imposto é igual ao retorno após o imposto. Relembrando-se que, em equilíbrio, as taxas de retorno após o imposto de ativos de risco semelhante são idênticas, pode-se relacionar o retorno acumulado líquido do imposto de um ativo com o retorno após o imposto de um título sem benefício fiscal, $b$, de mesmo risco ${ }^{5}$ :

$$
\frac{\$ 1(1+R)^{n}\left(1-\tau_{n}\right)}{\$ 1\left(1-\tau_{0}\right)}=\left(1+r_{b}\right)^{n}
$$

Equação 3 - equilíbrio de mercado expresso como igualdade dos retornos

Onde $R$ é o retorno pré-imposto, $\tau_{n}$ é a alíquota marginal do imposto em $n, \tau_{0}$ é a alíquota marginal em 0 e $r_{b}$ é o retorno pós-imposto de ativo de risco semelhante ao do investimento.

Ao se pôr matematicamente em evidência na Equação 3 o retorno do investimento antes do imposto, tem-se que:

$$
R=\left[\frac{\left(1+r_{b}\right)^{n}\left(1-\tau_{0}\right)}{\left(1-\tau_{n}\right)}\right]^{1 / n}-1
$$

Equação 4 - expressão do retorno bruto de um investimento

Como já dito, o efeito da redução de alíquota de imposto seria equivalente ao de uma depreciação acelerada. Supondo valores de $r_{b}=7 \%, \tau_{0}=40 \%$ e $\tau_{n}=30 \%$, o retorno anual antes do imposto no período de 5 anos seria de $R=\left[\frac{(1+0,07)^{5}(1-0,4)}{(1-0,3)}\right]^{1 / 5}-1=3,75 \%$ a.a.

\footnotetext{
${ }^{5}$ Scholes et al (op. cit., p. 127-130) explicam a importância de se ajustar os riscos de ativos que possuam riscos diferentes. Por isso, ao longo da tese, quando se disser que os ativos têm, por pressuposto, riscos iguais ou semelhantes, entenda-se que os riscos já foram devidamente ajustados. O ajuste proposto pelos autores é efetuado por meio do CAPM, capital asset pricing model.
} 
A taxa de retorno pré-imposto requerida, de 3,75\%, é bem inferior ao retorno pós-imposto obtido pelo ativo tributado desfavoravelmente $(7 \%)$. A razão para tanto é que o governo concedeu um benefício fiscal de $40 \%\left(\tau_{0}\right)$ sobre o investimento, mas requereu apenas $30 \%$ $\left(\tau_{n}\right)$ dos retornos gerados por esse investimento. Como conseqüência desse favor tributário, investidores demandariam mais pelo investimento, aumentando seu preço e causando um retorno antes do imposto abaixo do retorno obtido por um título de mesmo risco. Pela equação (3), vê-se que $3,75 \%$ ao ano de retorno antes do imposto do ativo, pelo período de 5 anos, resulta em idêntico retorno após impostos de um título tributado (ou mesmo isento) cujo retorno anual, após impostos, seja de 7\% aplicado pelo mesmo período.

O retorno antes do imposto obtido pelo ativo favorecido tributariamente foi reduzido por uma tributação implícita. No caso da depreciação acelerada, o tributo implícito não é pago para governos; ele é revertido a favor dos consumidores (por meio de uma redução de preços dos produtos) e/ou a favor dos fornecedores dos fatores de produção (por meio de acréscimos de preços dos insumos).

A pesquisa empírica tem demonstrado que a comprovação da tributação implícita não é trivial, em especial porque é difícil isolar-se os efeitos tributários dos efeitos causados pelos riscos dos diversos ativos carregados pelos mais variados tipos de empreendimentos (ERICKSON; MAYDEW, 1998, p. 436). Black e Scholes (1974), por exemplo, sugeriram ser impossível demonstrar, utilizando o que então de melhor havia em termos de metodologia empírica, que o retorno esperado sobre ações ordinárias com alta distribuição de dividendos seria diferente do retorno esperado sobre ações ordinárias com baixa distribuição de dividendos, fosse o retorno medido antes ou depois dos impostos.

Não obstante a difícil comprovação, a tributação implícita pode ser tão ou mais significativa que a explícita, apesar das expressivas diferenças entre elas. A oposição do termo "tributação explícita" ao termo "tributação implícita" demarca bem as dessemelhanças entre os dois tipos de tributação. O adjetivo "implícita" já demonstra, por si só, que existe um tipo de tributação “invisível” ou menos aparente que a explícita. Tributação explícita é aquela formalmente determinada pela legislação tributária: é a que estabelece, ocorrido um fato específico e previsto em lei, a aplicação de uma alíquota regulamentar sobre uma base de cálculo 
expressamente definida, resultando no imposto devido que deverá ser provisionado nas demonstrações contábeis e recolhido posteriormente aos cofres públicos.

A tributação implícita, por outro lado, não está diretamente prevista nas regras tributárias (ela é uma conseqüência delas), não requer provisionamento, tampouco está sujeita a recolhimento. Quanto ao momento de incidência, a tributação implícita precede a explícita: a perda de retorno implícita ocorre antes da perda ocasionada pelos impostos explícitos. A unilas, a despeito das suas diferenças, "apenas" o fato de que ambas - tanto a tributação explícita quanto a implícita - são igualmente reais (SCHOLES et al, op. cit., p. 126).

No Brasil, o tema tributação implícita ainda é pouco explorado. Mesmo nos EUA, onde o tema já é estudado desde os anos 90 (um dos primeiros artigos sobre tributação implícita foi o de Shackelford, de 1991, The market for tax benefits: Evidence from leveraged ESOPS), ainda existe bastante desinformação acerca do assunto. A pouca informação sobre tributos implícitos limita a alcance e a profundidade que todo debate sobre tributação merece. Além disso, as discussões sobre tributos vêm, não raro, revestidas de argumentos mais ideológicos do que propriamente técnicos. É o caso, por exemplo, de setores "acusados" de ter muito lucro, mas que, por outro lado, não pagariam os impostos na mesma proporção: sem provas concretas ou rigorosas para suportá-las, as acusações ganham terreno junto ao público em geral, que, às vezes, seja por má fé dos acusadores ou pela complexidade do assunto, é induzido a adotar a idéia de que determinados setores gozam de privilégios tributários injustamente concedidos.

Nos EUA, uma organização intitulada Citizens for Tax Justice, em estudo publicado em 1985, estimou e divulgou as alíquotas de imposto efetivas (quociente entre valor pago de tributos e lucro antes do imposto de renda) de corporações lucrativas, concluindo que elas pagaram pouco ou nada de tributos explícitos. O Congresso norte-americano votou então a favor de uma lei que passou a cobrar um pagamento de tributos mínimo, conhecido como AMTBIA, alternative minimum tax book income adjustment, em grande parte pressionado pela percepção pública de que corporações pagavam pouco a título de impostos explícitos, enquanto reportavam ao mesmo tempo lucros significativos para os acionistas. É possível que um entendimento mais aprofundado a respeito dos meandros tributários conduzisse a outras conclusões, talvez menos apaixonadas. Scholes et al (op. cit., p. 134) destacam que não houve, nesse estudo apresentado pelo Citizens for Tax Justice (nem em outros tantos, 
inclusive da área acadêmica, segundo os autores), preocupação com os tributos pagos implicitamente, o que pode ter contribuído para conclusões incompletas ou enganosas e até para a aprovação, talvez mais calcada em idéias equivocadas do que numa análise precisa dos fatos, de leis tributárias que alteraram significativamente o dia-a-dia de empresas e pessoas.

\subsection{Caso Compaq: desconsideração da tributação implícita nas Cortes Americanas}

Tampouco o Judiciário norte-americano parece conhecer os fundamentos da tributação implícita. Michael S. Knoll, da University of Pennsylvania Law School, escreveu um artigo intitulado Compaq Redux: Implicit Taxes and the Question of Pre-tax Profit ${ }^{6}$, de 2006, em que defende a posição de que, em um caso levado aos tribunais norte-americanos, as duas instâncias judiciais se enganaram nas suas sentenças, por terem desconsiderado a tributação implícita nos seus julgamentos.

No dia 16 de setembro de 1992, a Compaq comprou ações da Royal Dutch Shell, negociadas sob a forma de ADRs, American Depositary Receipts, na bolsa de Nova York, imediatamente antes do recebimento de dividendos e as vendeu imediatamente após o recebimento dos dividendos. Essa operação é conhecida internacionalmente como dividend-stripping. A Compaq permaneceu com as ações por apenas uma hora. Em valores, comprou as ações por US\$ 887,5 milhões, vendeu-as por US\$ 868,4 milhões, recebeu US\$ 22,5 milhões de dividendos da Shell, incorreu em custos de US\$ 1,4 milhão e ainda teve um imposto retido na Holanda de US 3,4 milhões.

Operações de dividend-stripping nos EUA possuem vantagens tributárias. A Compaq, por ser uma companhia norte-americana, é tributada nos EUA em bases universais. Os dividendos recebidos foram tributados nos EUA à alíquota de 35\%, o que gerou, em decorrência do recebimento dos dividendos, um imposto de renda devido de US\$ 7,9 milhões. Os custos da operação e a perda de capital resultante da diferença entre os preços de venda e compra das ações são dedutíveis pelas regras tributárias norte-americanas, por isso o passivo tributário decorrente dos dividendos recebidos reduziu-se para US\$ 0,7 milhão $(\$ 7,9-[((\$ 887,5+\$ 1,4)$ - $\$ 868,4) \times 35 \%])$. A Compaq ainda reclamou o direito de compensar o imposto retido na

\footnotetext{
${ }^{6} \mathrm{O}$ título do artigo traz apenas o nome da Compaq, mas uma outra operação, com as mesmas características da operação sob análise, foi também realizada pelas IES Industries e é citada no desenvolvimento do paper.
} 
Holanda. Utilizou o argumento de que a receita dos dividendos, vinda de fora dos EUA, foi alcançada pela tributação norte-americana, por isso nada mais justo que o imposto incidente sobre aquela receita fosse também admitido como crédito da empresa. O fluxo de caixa da Compaq com a operação de compra e venda das ações da Shell, levando-se em consideração apenas o pagamento (nos EUA e na Holanda) dos tributos explícitos e de acordo com o que pretendia a companhia, foi então como se segue:

\begin{tabular}{|c|c|}
\hline \multicolumn{2}{|c|}{ Entrada de recursos } \\
\hline Venda das ações & $\$ 868,4$ \\
\hline Dividendos & 22,5 \\
\hline Imposto a compensar & $\underline{3,4}$ \\
\hline Total de entradas & $\$ 894,3$ \\
\hline \multicolumn{2}{|c|}{ Saída de recursos } \\
\hline Compra das ações & $(\$ 887,5)$ \\
\hline Despesas & $(1,4)$ \\
\hline Imposto retido na Holanda & $(3,4)$ \\
\hline Imposto a pagar nos EUA & $(0,7)$ \\
\hline Total de saídas & $(\$ 893,0)$ \\
\hline Resultado da operação & $\$ 1,3$ \\
\hline
\end{tabular}

No breve período em que foi detentora do lote de ações da Shell, a Compaq obteve um lucro de US\$ 1,3 milhão. Tudo ótimo, não fosse o entendimento do IRS, Internal Revenue Service, a Receia Federal americana.

Com o argumento de que a transação carecia de substância econômica, uma vez que supostamente a Compaq já teria certeza quanto ao resultado negativo antes dos impostos, o IRS glosou as deduções referentes às perdas de capital e às despesas, bem como rejeitou a pretensão da companhia de compensar o imposto retido na Holanda. Em resposta, a Compaq ingressou em juízo, que em primeira instância deu razão ao físco. O abuso de forma, como também é conhecida a transação com ausência de substância econômica, foi caracterizado pelo juízo de instância inferior, em teste aplicado sobre o resultado antes dos impostos (pretax profit). Esse teste condiciona a existência de abuso de forma ao resultado da transação antes dos impostos explícitos pagos nos EUA, mas depois dos impostos pagos na Holanda: se houve prejuízo, há abuso de forma, do contrário aceita-se a transação para fins tributários. A idéia do pre-tax profit test é segregar as transações que visem tão-somente à economia tributária de outras transações que visem a outros interesses. A interpretação da primeira instância, que entendeu que a transação deu prejuízo antes do imposto pago nos EUA, está numericamente demonstrado abaixo: 
Tabela 2 - resultado da operação, baseado no pre-tax profit, de acordo com o IRS e a primeira instância do Judiciário norte-americano (depois de pago o imposto na Holanda, mas antes do imposto pago nos EUA)

\begin{tabular}{cc}
\multicolumn{2}{c}{ Em milhões de US\$ } \\
\hline \multicolumn{2}{c}{ Entrada de recursos } \\
\hline Venda das ações & $\$ 868,4$ \\
Dividendos & $\underline{22,5}$ \\
Total de entradas & $\$ \mathbf{8 9 0 , 9}$ \\
Saída de recursos & \\
Compra das ações & $(\$ 887,5)$ \\
Despesas & $(1,4)$ \\
Imposto retido na Holanda & $\underline{(3,4)}$ \\
Total de saídas & $(\$ \mathbf{8 9 2 , 3 )}$ \\
\hline Resultado da operação & $\mathbf{( \$ 1 , 4 )}$ \\
\hline
\end{tabular}

Em linha com o fisco americano, a primeira instância concluiu que houve prejuízo premeditado antes do imposto e que portanto as glosas deveriam ser mantidas. Inconformada, a Compaq recorreu à segunda instância, que lhe foi favorável. Segundo entendimento da instância superior, os impostos pagos na Holanda e nos EUA deveriam ter tratamento idêntico: ambos deveriam ser excluídos do pre-tax profit test. Assim procedendo, o resultado da operação foi positivo, como se vê abaixo:

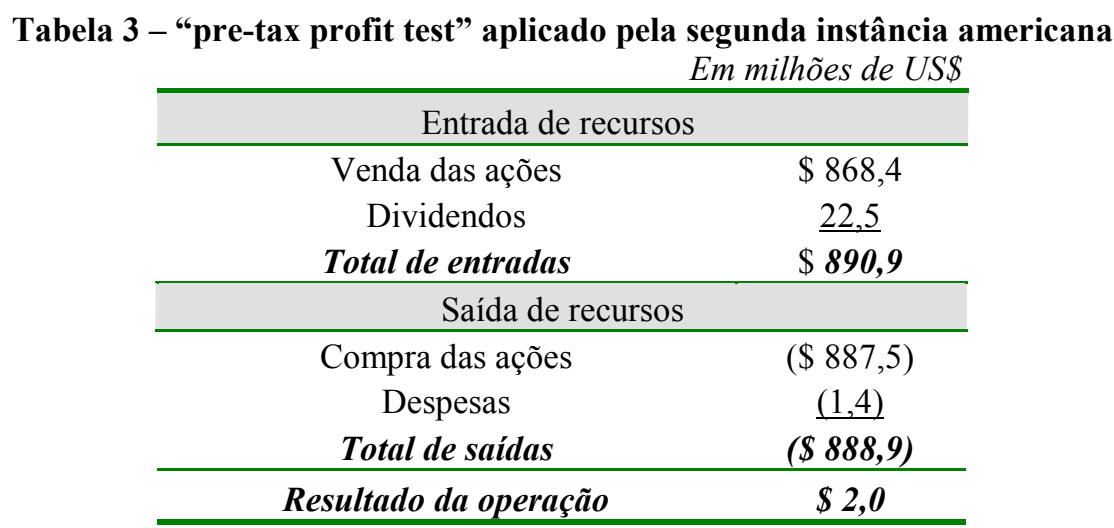

A decisão da segunda instância foi no sentido de que a Compaq garantiu um resultado positivo antes dos impostos - a empresa teria logrado êxito na realização de um tipo de arbitragem $^{7}$, tendo, por isso, o direito de aproveitar como crédito o imposto retido na Holanda.

Knoll avança em seu artigo informando que muitos comentaristas admitem que a transação da Compaq foi lucrativa antes dos impostos, mas que sugerem medidas para modificar o pre-tax

\footnotetext{
${ }^{7}$ Para a teoria de finanças, uma operação de arbitragem é uma operação financeira na qual não se investe nenhum capital inicial e se realiza um ganho certo sem correr nenhum risco. Na prática, o conceito de arbitragem é usado para descrever operações que envolvem pouco risco, como comprar (barato) em um mercado e revender (mais caro) em outro mercado, ativos muitos semelhantes. (GARCIA; DIDIER, 2001, p. 4).
} 
profit test para esse tipo de transação ou mesmo trocá-lo por outro que permita separar arbitragens tributárias de arbitragens econômicas. No entanto, Knoll afirma que o Judiciário, a Compaq e os comentaristas aplicaram o pre-tax profit test incorretamente. Se aplicado corretamente, diz ele, a segunda instância teria rejeitado as transações. Bastaria que fossem introduzidos os tributos implícitos.

Os detalhes da conclusão de Knoll serão esmiuçados à frente, pois há outros conceitos associados à tributação implícita que devem ser introduzidos. Por ora, recorde-se que a Compaq comprou as ações da Shell por US\$ 887,5 milhões e vendeu-as por US\$ 868,4 - uma redução do preço de venda de US\$19,1 milhões em relação ao preço de compra. Note-se que a redução não foi precificada pelo valor bruto dos dividendos distribuídos (US\$ 22,5 milhões), mas pelo valor dos dividendos líquidos do imposto retido na Holanda (US\$ 22,5 milhões - US\$ 3,4 milhões). Isso significa que o mercado de ações da Shell era "feito" por investidores que não se aproveitariam do imposto retido na Holanda. Os investidores marginais (que "fazem" o mercado) das ações da Shell compraram-nas já sabendo que não iriam se aproveitar do imposto retido na Holanda. Como a Compaq entendia que tinha todas as condições de aproveitar o imposto pago no exterior e ainda obter vantagem fiscal com a perda de capital, para ela essa perda deveria ter sido de US\$ 22,5 milhões (dividendos brutos). Como a perda de capital foi de apenas US\$ 19,1 milhões, a Compaq pagou implicitamente, ao comprar as ações, um valor de US\$ 3,4 milhões.

Comparada com os investidores marginais das ações da Shell, a Compaq tinha uma tributação favorecida. No caso, ela pagou implicitamente um tributo de US\$ 3,4 milhões no momento da compra das ações da Shell. Portanto, adicionando-se o que se pagou implicitamente ao custo de aquisição $(\$ 887,5+\$ 3,4)$, vê-se que a transação da Compaq gerou um resultado negativo antes de todos os impostos (implícitos e explícitos), como se comprova abaixo:

Tabela 4 - cômputo do resultado da operação da Compaq antes dos impostos implícitos e explícitos Em milhões de US\$

\begin{tabular}{cc}
\hline \multicolumn{2}{c}{ Entrada de recursos } \\
\hline Venda das ações & $\$ 868,4$ \\
Dividendos & $\underline{22,5}$ \\
Total de entradas & $\$ \mathbf{8 9 0 , 9}$ \\
Saída de recursos & \\
Compra das ações & $(\$ 890,9)$ \\
Despesas & $(1,4)$ \\
Total de saídas & $(\$ \mathbf{8 9 2 , 3 )}$ \\
\hline Resultado da operação & $(\$ \mathbf{1 , 4 )}$ \\
\hline
\end{tabular}


Cabe salientar que, apesar de os resultados obtidos no pre-tax profit test realizado pelo IRS (Tabela 2) terem se igualado ao teste em que todos os tributos entram no cálculo (Tabela 4), as concepções são totalmente diferentes. Basta que se admita por hipótese que o imposto retido na Holanda tivesse sido retido nos EUA. Voltando à Tabela 2, tal hipótese levaria à conclusão de que a operação seria lucrativa antes dos impostos, como no cômputo feito pela segunda instância judiciária norte-americana (Tabela 3). Fica evidente que, pela lógica do $I R S$ nesse caso, a forma prevaleceu sobre a essência, pois economicamente é irrelevante se os impostos foram pagos nos EUA ou na Holanda. A tributação implícita tem suas raízes fincadas na teoria econômica, por isso fica prejudicada uma visão eminentemente legalista.

\subsection{A perspectiva contratual e a tributação implícita}

A perspectiva contratual ${ }^{8}$ que emerge dos três temas centrais de Scholes-Wolfson ("todas as partes, todos os tributos e todos os custos") revela a importância da tributação implícita. Pode ser nociva a decisão quanto à estrutura de capital mais apropriada sem que se analise, simultaneamente, como serão tributados os retornos de potenciais financiadores e acionistas (SCHOLES et al, op. cit., p. 6).

Scholes et al (op. cit., p. 6) dão como exemplo uma empresa que deve decidir entre comprar ou arrendar uma máquina. Eles comentam que nos EUA, assim como na maioria dos países, o governo incentiva o investimento em bens de capital permitindo que máquinas, equipamentos e prédios sejam depreciados rapidamente para fins fiscais. Empresas podem, assim, deduzir, na apuração do imposto de renda, o custo de aquisição dos seus investimentos numa velocidade superior à depreciação econômica desses ativos. Alternativamente, se uma empresa arrenda bens ou equipamentos, as prestações pagas também são dedutíveis fiscalmente. Comparando-se a depreciação acelerada ao arrendamento, o valor presente das deduções das prestações do arrendamento é freqüentemente bem menor que o valor presente das deduções relativas às depreciações.

\footnotetext{
${ }^{8}$ Scholes et al (op. cit., p. 3) assim definiram perspectiva contratual: "Contracts specify the rights of various parties to make decisions and to receive cash flows in differing circumstances. We focus on how the tax-related cash flows specified by contracts affect the prices at which assets are traded. We further stress how these cash flows affect the ways in which production is organized by business units".
} 
Mesmo nessas condições, não se pode concluir, dizem os autores, que a compra dos ativos minimize os impostos de todas as empresas que utilizem máquinas e equipamentos. Empresas com baixa tributação podem ficar em melhor situação se abrirem mão das vantagens tributárias proporcionadas pela alta taxa de depreciação e optarem pelo arrendamento. Para assim proceder, as empresas com baixa tributação "vendem" o benefício fiscal da depreciação para empresas com alta carga de tributação, que, em troca, reduzem a taxa de arrendamento dos equipamentos.

Tributos implícitos são aqueles que incidem sobre ativos favoravelmente tributados (comparados com ativos menos favorecidos tributariamente e de risco similar), reduzindo-lhes o retorno antes dos impostos explícitos. No exemplo da decisão entre comprar ou arrendar equipamentos, uma redução na taxa de arrendamento é requerida pelos arrendatários para que eles abram mão de adquirir os equipamentos. A redução na taxa de arrendamento diminui a taxa de retorno antes dos impostos obtida pelos arrendadores. Os arrendadores aceitam perder parte do seu retorno antes dos impostos, em troca dos benefícios fiscais proporcionados pela propriedade dos equipamentos a arrendar. Em outras palavras, os arrendadores pagam tributos implícitos aos arrendatários, na expectativa de obter reduções maiores no pagamento de tributos explícitos.

\subsection{Objetivos da pesquisa}

Ao longo desta introdução, foram apresentadas situações para as quais o conhecimento sobre tributação implícita seria extremamente útil. Os exemplos do Citizens for Tax Justice, da operação de stripping-dividends realizada pela Compaq e da decisão entre comprar ou arrendar um equipamento foram pinçados da realidade norte-americana. Nem por isso deve-se deixar de acreditar ser possível aplicar os fundamentos da tributação implícita a situações similares ou mesmo a outras no Brasil. Um exemplo simples, porém importante, de aplicação da tributação implícita nas decisões que envolvem tributos no Brasil é quanto à melhor forma de tributação, se pelo lucro presumido ou pelo lucro real. Sem a inclusão da tributação implícita, a escolha poderá recair sobre o tipo de tributação mais gravosa, isto é, aquela que, no total de impostos explícitos e implícitos, resultará em maior pagamento de tributos. 
São três os objetivos desta pesquisa. Primeiro, apresentar os principais conceitos e fundamentos da tributação implícita. A teoria econômica e os conceitos advindos dela constituem o ferramental básico para se compreender a parte empírica da tese. Segundo, testar empiricamente a existência de tributação implícita decorrente da isenção introduzida pela MP $n^{0}$ 281/2006, que causou reações de forte cunho ideológico. Publicada em 16 de fevereiro de 2006, essa MP, medida provisória, isentou de imposto de renda os rendimentos produzidos por títulos públicos federais adquiridos por investidores estrangeiros a partir da data da publicação da MP. Uma das intenções dessa isenção era reduzir os juros pagos por títulos públicos federais. O então secretário do Tesouro Nacional, Joaquim Levy, afirmou que a economia de juros seria resultante do aumento da procura por papéis federais (Diário da Manhã, edição de 17/02/2006). As palavras do secretário do Tesouro revelam que a isenção concedida pelo governo brasileiro trazia subjacente a idéia de tributação implícita. O terceiro objetivo é analisar empiricamente uma situação correlata à MP n ${ }^{\circ}$ 281/2006 que ocorreu não propriamente por causa da MP, mas devido à falta de liquidez dos papéis comprados pelos estrangeiros. A falta de liquidez trouxe uma nova oportunidade de se comprovar empiricamente a tributação implícita, com a vantagem adicional de se explorar outro ângulo de um fenômeno multifacetário.

Assim, a tese divide-se em cinco capítulos: seguinte à introdução, o capítulo 2 apresenta os fundamentos econômicos e os relevantes conceitos de investidor marginal e clientela tributária, assim como a revisão da literatura; o capítulo 3 apresenta as evidências que indicam a preferência do investidor estrangeiro pela NTN-B, a seleção da amostra a ser utilizada nos testes empíricos, a forma como os dados foram coletados e as principais características da NTN-B; o capítulo 4 expõe a metologia utilizada para comprovar a tributação implícita, a saber, a análise de séries de tempo associada a uma técnica conhecida como análise de intervenção. Conhecidos os principais fundamentos da técnica a ser aplicada, o capítulo 4 passa a dedicar-se à comprovação da tributação implícita em dois momentos: o primeiro, quando o investidor estrangeiro entrou maciçamente comprador da NTN-B; num segundo instante, quando esse mesmo investidor resolveu sair de um mercado de baixa liquidez. Nesse capítulo, portanto, apresentam-se os modelos das NTN-B relativos ao primeiro momento (entrada do investidor), suas especificações, desde a fase de identificação até a análise dos resultados, passando pelas fases de estimação e adequação; em seguida, o capítulo 4 encerra com a análise e a comprovação da tributação implícita nascida da falta de liquidez encontrada 
pelo investidor estrangeiro, que quis se desfazer das NTN-B recém-compradas, mas que encontrou um mercado ilíquido para vendê-las; a conclusão, no capítulo 5, fecha a tese, com os principais pontos apresentados e as possíveis contribuições desta pesquisa. 


\section{REFERENCIAL TEÓRICO}

\subsection{Conceitos e fundamentos}

\subsubsection{Fundamentação econômica da tributação implícita}

A tributação implícita tem como fundamento econômico o equilíbrio de mercado. O equilíbrio Walrasiano ou equilíbrio geral competitivo, como também é conhecido o equilíbrio de mercado, é obtido quando a oferta agregada iguala-se à demanda agregada no mercado de bens e fatores. No mercado nacional de títulos, o equilíbrio geral é encontrado pelo cruzamento das curvas de oferta e demanda de títulos brasileiros. Por simplificação, adota-se aqui o pressuposto de que o governo brasileiro oferta, inelasticamente, uma quantidade de títulos dada por $B$. O gráfico abaixo mostra o equilíbrio de mercado de títulos brasileiros demandados por investidores brasileiros e estrangeiros, dada uma quantidade ofertada constante, onde $B$ é a quantidade de títulos ofertada e (1/r) é a razão inversa do retorno bruto desses títulos ${ }^{9}$ :

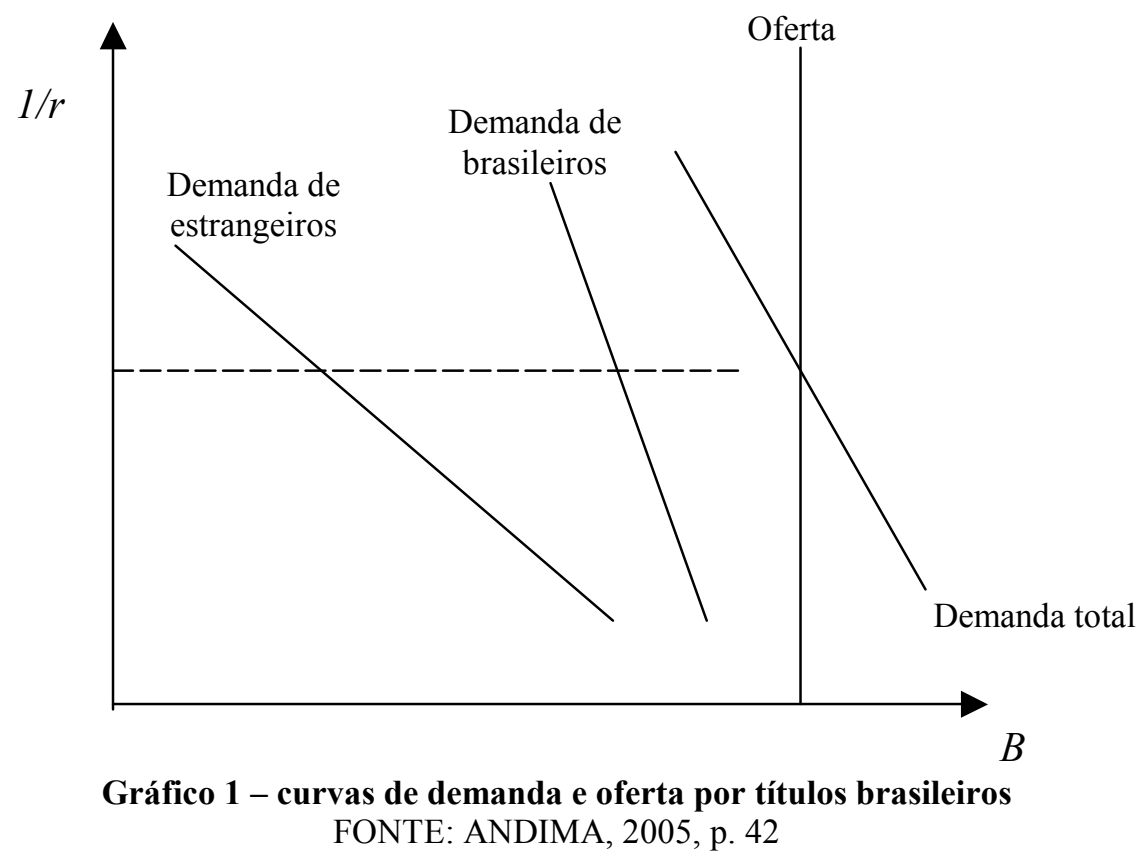

\footnotetext{
${ }^{9} \mathrm{O}$ eixo das ordenadas, classicamente nas representações das curvas de demanda e oferta, contém preços. Como se pretende verificar o efeito que um aumento de demanda causaria sobre o retorno dos títulos, os valores das ordenadas foram substituídos por $1 / r$, pois, dessa forma, visualizam-se prontamente as conseqüências do movimento das curvas de demanda sobre o retorno bruto. Por óbvio, o uso de $1 / r$ deixa as curvas de demanda e oferta idênticas ao uso de preços no eixo das ordenadas.
} 
A exposição de motivos da MP $n^{0}$ 281/2006 é clara quanto à intenção de aumentar a participação do investidor estrangeiro na composição da Dívida Pública:

\begin{abstract}
(...)
3. A possibilidade de aumentar a participação de investidores não residentes poderá resultar em importantes benefícios na administração da dívida pública federal e em economia na despesa na conta de juros. Isto porque, a maior participação do investidor estrangeiro pode ajudar a diminuir a percepção de risco associada à dívida e, destarte, o prêmio pago pelo Tesouro Nacional na emissão de seus títulos. De fato, há importantes segmentos de investidores estrangeiros que têm preferência por investimentos em títulos de longo prazo, principalmente prefixados ou indexados a índice de preços, características estas que estão em consonância com as diretrizes da administração da Dívida Pública Mobiliária Federal interna-DPMFi. A expectativa, baseada na experiência de outros países, é que uma maior participação do investidor não residente no conjunto de detentores de títulos públicos dê celeridade à política de alongamento dos prazos de vencimento da DPMFi e de ampliação da participação de títulos pré-fixados na sua composição, processo que vem ocorrendo nos últimos anos, mas que pode ser acelerado, mantida a melhora das condições econômicas que o país vem conquistando. Assinale-se que, em outros países, a ampliação do mercado de títulos de longo prazo na esteira da maior participação dos investidores não residentes veio a funcionar como elemento indutor da maior participação nesse mercado também do investidor residente.
\end{abstract}

4. A melhoria do perfil da dívida pública, é bem sabido, tem o potencial de induzir implicações positivas para diversas áreas, inclusive para o setor produtivo. A menor volatilidade financeira e a ampliação dos efeitos da política monetária, que podem advir da medida, são apenas os efeitos mais diretos. A melhoria tende a se transmitir a todo o mercado de renda fixa, favorecendo a queda dos custos, o aumento dos prazos e a ampliação das possibilidades de captação de recursos pelas empresas privadas. O barateamento do investimento produtivo é um importante ingrediente para a criação do emprego, o aumento da renda e o crescimento econômico.

(...)

7. É nesse sentido que propomos reduzir a zero a alíquota do imposto de renda incidente sobre os rendimentos de investidores não residentes em títulos públicos federais.

Graficamente, um aumento de demanda estrangeira por títulos públicos provocaria deslocamento da curva de demanda dos investidores estrangeiros, já que eles passariam a perceber retorno maior em termos líquidos. Como resultado dessa mudança, a demanda total por títulos também se desloca, e o novo juro de equilíbrio passa a ser menor, como mostra o gráfico abaixo: 


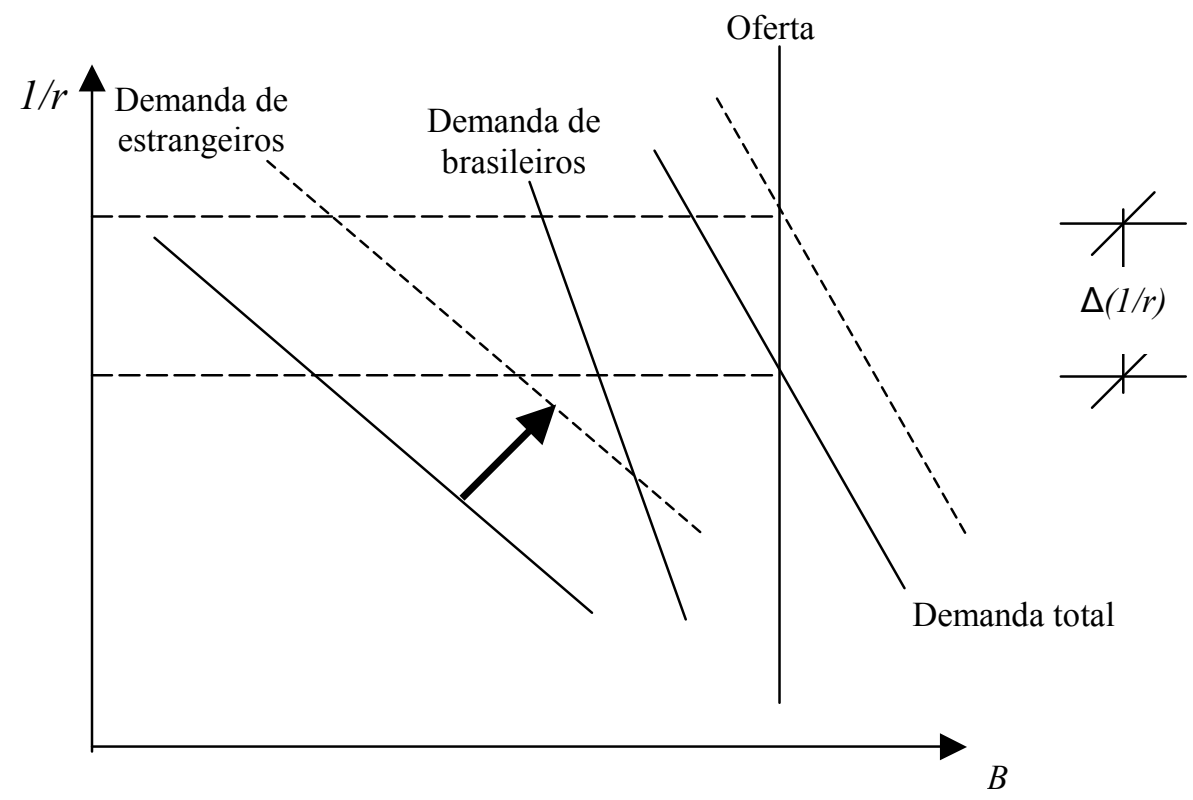

Gráfico 2 - aumento demanda estrangeira por títulos brasileiros FONTE: ANDIMA, 2005, p. 43

O aumento de $(1 / r), \Delta(1 / r)$, ocorreria em virtude de uma redução de $r$, ou seja, a expectativa de uma desoneração de imposto de renda nos rendimentos adquiridos por estrangeiros era de, além de um alongamento do perfil da dívida, uma redução do retorno dos títulos emitidos pelo governo brasileiro. É evidente que a redução do retorno bruto é a própria tributação implícita.

Como superficialmente mencionado na introdução, o movimento da curva de demanda estrangeira no mercado secundário só é possível se houver um tipo especial de investidor para o qual seja indiferente manter ou vender o título público beneficiado tributariamente, o investidor marginal.

\subsubsection{Investidor marginal e clientela tributária}

Todo e qualquer contribuinte suporta uma carga tributária total igual à soma de tributos implícitos e explícitos. Aqueles que pertencem a uma determinada classe de contribuintes tributada à alíquota regulamentar de $30 \%$, por exemplo, seriam indiferentes entre investir em títulos que retornassem $10 \%$ antes do imposto ou em títulos isentos que retornassem $7 \%$. Tais contribuintes seriam indiferentes entre pagar todo o imposto implicitamente, explicitamente ou qualquer combinação que resultasse num imposto total de $30 \%$. Os contribuintes que são indiferentes entre investir em dois ativos de mesmo risco, mas cujos retornos sejam tributados 
diferentemente, são chamados investidores marginais. Os investidores que têm alíquotas explícitas diferentes das alíquotas explícitas suportadas pelo investidor marginal não são indiferentes à escolha de dois ativos de mesmo risco e diversamente tributados e são chamados de investidores inframarginais (SCHOLES et al, op. cit., p. 130).

Contribuintes com carga tributária semelhante demandam investimentos semelhantemente tributados. Investidores com alta tributação marginal explícita preferirão, voltando ao exemplo dos títulos norte-americanos, os títulos municipais (isentos). Investidores com baixa alíquota de imposto marginal optarão pelos títulos sem favorecimento fiscal. Investidores ou contribuintes que prefiram um investimento a outro compõem o que se convencionou chamar de clientela tributária (tax clientele). A menos que identifiquem corretamente o seu tipo de clientela tributária, os investidores não maximizarão suas taxas de retorno após os impostos (SCHOLES et al, op. cit., p. 130).

Suponha-se, por exemplo, que a tributação implícita nos títulos municipais seja de $30 \%$ e que os títulos federais (totalmente tributados) retornem 10\% antes do imposto. A clientela para os títulos federais é formada por investidores com alíquota explícita de imposto marginal abaixo de 30\%. Um investidor tributado a uma alíquota marginal explícita de 20\% ganharia 8\%, líquido do imposto, se investisse nos títulos federais, $1 \%$ a mais do que se investisse nos títulos municipais. Essa clientela estaria em melhor situação ao investir em títulos federais, pois pagaria $20 \%$ de tributos explícitos em lugar de investir em títulos municipais sobre os quais pagaria tributos implícitos de 30\% (SCHOLES et al, op. cit., p. 130).

Analogamente, um investidor cuja alíquota marginal fosse de $40 \%$ estaria em condição mais vantajosa se investisse nos títulos municipais, sobre os quais pagaria um tributo implícito de $30 \%$, em vez de optar por investir nos títulos federais, cuja tributação lhe levaria $40 \%$ de tributos explícitos. Enquanto a alíquota de imposto implícita incidente sobre um dado ativo é a mesma para todos os investidores ${ }^{10}$, a alíquota explícita varia entre os investidores. Contribuintes com alta tributação explícita tendem a investir em ativos com alta carga de tributação implícita (SCHOLES et al, op. cit., p. 130). Apenas os investidores marginais não

\footnotetext{
${ }^{10}$ Basta ver a Equação $1, \tau_{\text {implicita }}=\left(R_{b}-R_{a}\right) / R_{b}$, para se chegar a essa conclusão. Intuitivamente, pode-se chegar à mesma conclusão: no exemplo dos títulos municipais norte-americanos, todos os seus detentores recebem o mesmo retorno antes do imposto, $7 \%$. Mas esses mesmos detentores poderiam investir em títulos tributados (federais, no exemplo) e obter um retorno de $10 \%$ antes do imposto. A idéia da tributação implícita não deixa de trazer subjacente, ainda que superficialmente, a noção de custo de oportunidade.
} 
possuem um padrão de investimento (ou "lealdade a marcas"): na ausência de custos de transação, eles investiriam e desinvestiriam em ativos isentos ou não, ao sabor das mudanças nos preços relativos (SCHOLES et al, op. cit., p. 130). É esse comportamento racional que torna o investidor marginal um elemento fundamental na existência da tributação implícita.

Imagine-se uma curva de retornos constantes, $R_{t}=R_{t+1}$, e uma redução do imposto de renda incidente sobre rendimentos de títulos públicos negociados no mercado secundário e adquiridos por estrangeiros após o período $t$. Suponha-se também que os investidores nacionais detivessem integralmente esses títulos. Residentes não aproveitariam a isenção, mas os estrangeiros, por aproveitá-la, optariam pelo retorno obtido em $t+1$, já que, nessa data, o retorno pós-imposto seria maior para eles. Assim, uma pressão de demanda seria exercida em $t+1$ pelos investidores não-residentes, ocasionando uma redução do retorno em $t+1$, como ilustrado no Gráfico 2. Dito de forma alternativa, o investidor estrangeiro provocaria o aumento do preço do título em $t+1$; não haveria razão para que o investidor nacional, nesse momento, não se desfizesse desse título que se valorizou, vendendo o título ao investidor estrangeiro e se posicionando em outro título (público ou privado) de mesmo retorno (e risco), porém mais barato.

Se, ao contrário da hipótese acima, o investidor estrangeiro possuísse a integralidade dos títulos públicos no período anterior à isenção concedida a estrangeiros, ele não se desfaria dos títulos no período pós-isenção, porque ele próprio se beneficiaria do favor fiscal. A isenção seria inócua, pois, nesse caso, não haveria um investidor marginal dos títulos favorecidos. A expressão "marginal" advém do fato de ser um tipo de investidor que está à margem, no sentido de estar entre duas possibilidades, adaptando-se a definição de "margem" transcrita do Dicionário Michaelis: “elevação de terra lavrada e compreendida entre dois sulcos”. Nessa hipótese, a curva de demanda do investidor estrangeiro ficaria estática, sem a ocorrência, portanto, da tributação implícita.

No caso da operação de dividend-stripping realizada pela Compaq, descrita na introdução (item 1.2), mencionou-se que os impostos pagos na Holanda provavelmente não tinham valor para o investidor marginal das ações da Shell. Relembre-se que o preço obtido pela Compaq na venda das ações da Shell reduziu-se não do valor dos dividendos brutos recebidos, mas dos dividendos líquidos do imposto retido no exterior. As ações adquiridas pela Compaq possuíam uma perspectiva de ganho que o mercado (investidor marginal) não admitia. Como 
comentado por Knoll (2006), o mercado para as ações da Shell era composto pelos dois tipos de investidores - os que se aproveitariam do imposto retido no exterior e aqueles que não tirariam proveito da retenção realizada em outro país. Seria natural que se pensasse, nesse caso, que o preço de mercado fosse obtido por uma média das expectativas desses dois tipos de investidores. O equilíbrio nos mercados financeiros, entretanto, é determinado não pela média, mas pelo investidor marginal. Provavelmente porque a maioria dos investidores tivesse expectativa de receber todo ou nenhum crédito tributário em decorrência do imposto retido no exterior, um dos dois grupos (o que não via vantagem tributária no imposto retido no exterior) provavelmente foi responsável por "fazer" o mercado de ações da Shell. E a Compaq não compunha esse grupo.

\subsection{Revisão da literatura}

Segundo Maydew (2001, p. 395), talvez mais que qualquer outro tema na área tributária, a pesquisa sobre o grau de influência dos tributos na formação de preços de ativos está disseminada pela literatura produzida pelas áreas econômica, financeira e contábil. Maydew (op.cit., 2001, p. 395) demonstra, inclusive, preocupação com as diferenças terminológicas que dificultam a integração dos achados científicos oriundos de cada área. O termo tributação implícita (implict taxes) foi popularizado por Scholes e Wolfson, enquanto o termo tax capitalization $^{11}$ é o preferido entre economistas, apesar de ambos designarem o mesmo fenômeno (MAYDEW, 2001, p. 395 e SCHOLES op.cit., p. 131).

A diferença de terminologia, contudo, talvez seja o menor dos problemas. Os estudos que procuram comprovar a presença da tributação implícita são normalmente muito cautelosos acerca das suas conclusões. Não são poucas, de fato, as dificuldades metodológicas. Erickson e Maydew (op.cit., p. 435) comentam que pesquisas teóricas constataram que, em mercados com pelo menos dois ativos tributados diferentemente e com pelo menos dois investidores, a existência do equilíbrio de mercado sem arbitragens depende fundamentalmente da existência de fricções de mercado e das restrições impostas pelas regras tributárias. Dado o grande número de ativos diferentemente tributados e de investidores atualmente, bem como das inúmeras fricções e restrições tributárias que tentam prevenir a arbitragem tributária, a

\footnotetext{
${ }^{11}$ Tributos são ditos incorporados (capitalized) aos preços dos ativos quando seus preços correntes são menores do que seriam na hipótese da inexistência daqueles tributos.
} 
existência e a magnitude da tributação implícita são basicamente uma questão empírica (ERICKSON; MAYDEW, op.cit., p. 435).

As pesquisas que tentam evidenciar a existência da tributação implícita e da clientela tributária vêm produzindo resultados nem sempre conclusivos. Fama e French (1998) expõem que, de acordo com a literatura, muitos fatores, incluindo tributos, custos de solvência, custos de agência e assimetria informacional, exercem influência na relação entre valor da empresa e decisões de financiamento. Segundo os autores, exceto os tributos, todos os fatores significativos envolvidos na relação entre valor e operações de financiamento estão relacionados com a rentabilidade da empresa, ou seja, agem sobre a rentabilidade antes dos impostos. Os dois autores, no entanto, concluíram que, na comparação entre ações e títulos de dívida, os métodos empíricos então utilizados não eram suficientemente eficientes para captar os diferenciais de risco relacionados a cada um dos ativos, dificultando o isolamento dos efeitos tributários sobre os seus retornos.

Uma outra corrente da pesquisa empírica investiga o efeito causado por alterações inesperadas das regras tributárias sobre o retorno de ações. Erickson e Maydew (1988) examinaram a reação dos preços das ações à proposta de redução na dedução dos dividendos recebidos (DRD, pela sigla em inglês) por empresas. Os DRD são deduções do lucro tributável que companhias fazem dos dividendos recebidos de outras empresas sob seu controle. A intenção dessa dedução é amenizar os efeitos de uma tripla incidência. A tripla tributação ocorre porque num primeiro momento a empresa distribuidora dos dividendos paga esses dividendos com recursos já tributados (primeira tributação); a empresa recebedora dos dividendos está sujeita à tributação dos dividendos recebidos (segunda tributação); por fim, se a empresa que recebeu dividendos distribuí-los aos acionistas, estes serão também tributados (terceira tributação).

Inesperadamente, o governo americano anunciou que reduziria os DRD de $70 \%$ para $50 \%$. Se o tratamento tributário dado aos DRD fosse incorporado ao preço das ações de empresas que distribuem alto volume de dividendos, então, segundo a teoria, a redução dos DRD proposta inesperadamente pelo governo deveria reduzir o preço dessas ações. Erickson e Maydew (1988) reportam que os preços das ações preferenciais declinaram, mas os preços das ações ordinárias não tiveram o mesmo movimento. São resultados consistentes com o fato de as ações preferenciais, mas não as ordinárias, sofrerem a ação de tributação implícita decorrente 
da redução dos DRD. Em outras palavras, os resultados obtidos parecem indicar que as corporações são o investidor marginal das ações preferenciais, mas não das ações ordinárias.

Esse estudo de Erickson e Maydew (1998) possui virtudes metodológicas importantes, pois, por ser um estudo de evento, pode reduzir os potenciais problemas às vezes encontrados em outras metodologias. Um dos principais problemas encontrados por pesquisadores que investigam a tributação implícita está na utilização da estrutura de dados de corte transversal ${ }^{12}$ (cross-section data set) para comparar os retornos antes dos impostos de ativos favorecidos tributariamente com o retorno de ativos menos favorecidos. Segundo Erickson e Maydew (1998), assim como Fama e French (1998), é difícil isolar os efeitos tributários dos efeitos causados pelas diferenças de risco associadas aos vários ativos/empresas num determinado ponto do tempo. Os autores apontam três vantagens do seu estudo sobre outros estudos que procuram comprovar a tributação implícita em ações: (i) estudos anteriores estavam sujeitos à distorção causada pelas diferenças de risco associadas a dados em cross-section, por isso a metodologia adotada por seu estudo - a influência de um evento exógeno sobre o mesmo ativo - tende a reduzir o viés ocasionado por diferenças de risco entre os vários ativos num período específico; (ii) a proposta tributária do governo estudada foi específica, afetando apenas um tipo de ativo (ações que pagavam dividendos), cuja posse estava em mãos de um tipo de investidor (corporações); (iii) a proposta do governo visava mais a um tipo de ação do que a outro: ações com alta distribuição de dividendos provavelmente seriam mais afetadas que ações de baixa distribuição.

Ayers, Cloyd e Robinson (2002) também realizaram um estudo de evento (Revenue Reconciliation Act, de 1993 - RRA93). No caso, os autores examinaram o impacto nos preços das ações causado pelo aumento da tributação de dividendos recebidos por indivíduos. Eles utilizaram como proxy para representar o status tributário do investidor marginal o percentual das ações em propriedade de investidores institucionais ${ }^{13}$ (institutional ownership). O estudo mostrou evidências de que os preços das ações declinaram em maior grau para empresas que distribuíam mais dividendos, mas esse declínio foi mitigado pela influência dos investidores institucionais. Uma vez que o referido ato legal aumentava a tributação de indivíduos, o

\footnotetext{
${ }^{12}$ Wooldridge (2006) define um conjunto de dados de corte transversal como uma amostra de indivíduos, consumidores, empresas, cidades, estados, países ou uma variedade de outras unidades, tomada em um determinado ponto no tempo.

${ }^{13}$ Bancos, corretoras, fundos mútuos, investidores corporativos, companhias de seguro e fundos de pensão.
} 
esperado era que os investidores institucionais não tivessem tanta influência sobre a queda de preços das ações. O estudo demonstra os cuidados com conceitos correlatos à tributação implícita, como investidor marginal e clientela. Note-se que, se esse estudo não continha problemas metodológicos importantes, o aumento da tributação introduzido pelo governo não trouxe o resultado esperado, talvez pela identificação incorreta de quem seria o investidor marginal.

Dhaliwal, Li e Trezevant (2003) reportam evidências de que a tributação dos dividendos é incorporada ao preço de ações ordinárias. Além disso, verificaram que a política de distribuição de dividendos da empresa e o tipo de investidor que detém sua propriedade (investidor institucional, corporações, indivíduos etc.) influenciam o grau de desvantagem decorrente da tributação dos dividendos.

Vários estudos têm documentado que o preço pago por empresas incorpora os efeitos tributários das vantagens fiscais existentes nas empresas adquiridas. Assim, a empresa compradora desembolsará mais ou menos de acordo com o benefício tributário a ser transferido da empresa adquirida para a adquirente. Hayn (1989) examinou a influência dos atributos tributários sobre a motivação de aquisições de empresas. A importância das vantagens tributárias no processo de aquisição é determinada analisando-se a conduta de potenciais compradores e o impacto no preço das ações em resposta ao tratamento tributário concedido à operação de aquisição. Utilizando a metodologia de estudo de evento, a autora conclui que os atributos mais valorizados nas aquisições analisadas dependem da menor ou maior tributação suscitada pela operação: nas aquisições isentas de tributação ${ }^{14}$, valorizam-se mais o estoque de prejuízo fiscal, que pode ser utilizado para compensar imposto futuro, e os créditos tributários cuja utilização para reduzir imposto esteja próxima a decair; já nas operações tributadas, a característica mais importante é a reavaliação (step-up in basis) dos ativos adquiridos, que passam a ser contabilizados pela adquirente pelo valor de mercado ${ }^{15}$.

\footnotetext{
${ }^{14}$ Scholes et al (op. cit., p. 367) ressalvam que a expressão "sem tributação", que designa as aquisições em que o comprador utiliza majoritariamente ações para financiá-las, é uma designação indevida, pois essas operações resultam apenas numa postergação do pagamento do imposto até a venda das ações.

${ }^{15}$ A valorização (step-up in basis) a valor de mercado dos ativos adquiridos reduz o eventual ganho de capital na venda futura desses ativos, assim como a despesa de depreciação passa a ser mais vantajosa tributariamente, por ser calculada sobre uma base maior, do que se os ativos fossem recebidos pelo valor original registrado na empresa vendida. Não são, claro, operações livres de custo. Scholes et al (2005) discutem em profundidade, nos capítulos 13 a 17, as vantagens e desvantagens, inclusive tributárias, dos vários tipos de rearranjo societário nos EUA.
} 
Erickson (1998) dá evidências de que a tributação influencia as operações de aquisição de empresas. O autor demonstra que o status tributário da adquirente é determinante na escolha do tipo de aquisição (se tributada - financiada principalmente com dinheiro - ou livre de tributação - financiada majoritariamente com ações). Empresas adquirentes com baixa tributação (portanto, com reduzida vantagem na contratação de dívida) prefeririam realizar aquisições financiadas por ações (aquisições livres de tributação), consistente com a expectativa de que a probabilidade de ocorrência de uma aquisição realizada com troca de ações (sem tributação) é uma função crescente da probabilidade da exaustão tributária da empresa adquirente (a exaustão tributária é representada por uma variável binária, AcqNOL, que indica se a adquirente tem ou não estoque de prejuízo fiscal). Por outro lado, a ocorrência de uma aquisição tributada é tanto maior quanto maior a tributação suportada pela adquirente (maior vantagem fiscal na dedução dos juros). Subjacente à conclusão de Erickson, está a noção de clientela tributária e de que investidores, ao demandarem mais por ativos com tratamento tributário vantajoso para eles, forçam para cima o preço dos ativos adquiridos (portanto, reduzindo seu retorno antes dos impostos ou, alternativamente, causando o surgimento da tributação implícita). Erickson (1998) ainda conclui que seus testes fornecem pouca evidência de que a tributação sobre ganhos de capital dos acionistas das empresas adquiridas ou características tributárias e não-tributárias das dessas empresas-alvo influenciem a forma de escolha do tipo de aquisição.

Henning, Shaw e Stock (2000) examinaram os reflexos tributários suportados pela empresa adquirente e pela adquirida nas aquisições tributadas. Eles focam em três questões: (i) se a adquirente paga um preço mais elevado para compensar a adquirida e seus (da adquirida) acionistas pela tributação provocada pela transação. As aquisições de ativos impõem uma tributação sobre o ganho de capital auferido pela empresa adquirida, bem como sobre os acionistas da empresa-alvo se ela for liquidada; (ii) se o pagamento de tributos, decorrente da valorização a valor de mercado dos ativos adquiridos, resulta em um preço menor pago pela adquirente, e (iii) se a alíquota marginal do imposto da empresa adquirida, em face dos pagamentos contingentes futuros, influencia a forma de estruturação da transação. A operação de aquisição às vezes leva em conta a possibilidade de pagamentos contingentes futuros, como, por exemplo, pagamentos resultantes da performance futura da empresa-alvo. As regras tributárias norte-americanas geralmente postergam a tributação de aquisições com pagamentos contingentes até que eles efetivamente ocorram, e o comprador faça o desembolso final desses pagamentos. Esse benefício fiscal (postergação do pagamento do 
imposto) resulta em grandes incentivos para empresas-alvo com altas alíquotas marginais, o que pode ser levado em consideração no preço pago pela adquirente. Em suma, a propósito do artigo é examinar em que extensão os tributos pagos na aquisição, bem como a alíquota marginal da empresa adquirida, influenciam o preço em operações de aquisição. Os resultados obtidos sugerem que, em situações em que a adquirida e seus acionistas estão sujeitos à tributação, a adquirente paga mais pela empresa-alvo do que pagaria em transações em que a empresa-alvo é tributada apenas uma vez. Relativamente à valorização a valor de mercado dos ativos adquiridos, não se confirmou a hipótese de que o preço pago por eles seria menor em razão da incidência de tributos sobre o step-up in basis. Por fim, os autores encontraram evidências de que o potencial pagamento de contingências, combinado com a elevada alíquota marginal do imposto ostentada pela adquirida, reflete-se no preço acordado nas operações de aquisição tributadas.

O efeito causado pela dedutibilidade do goodwill, introduzida em 1993, sobre as aquisições corporativas foi investigado por Ayers, Lefanowicz e Robinson (2000). Os seus resultados evidenciam que a autorização legal (Omnibus Budget Reconcilation Act of 1993, OBRA) para dedutibilidade da amortização do goodwill está associada com o aumento dos prêmios pagos nas aquisições. Além disso, encontraram-se evidências de que os benefícios fiscais associados àquela amortização são repartidos, via preço de negociação, entre empresas adquirentes, adquiridas e seus acionistas. Este estudo recebeu comentários elogiosos de Maydew (2000), que, por outro lado, contribuiu com várias sugestões. Maydew (2000) entende que os testes resultantes da análise conjunta de aquisições realizadas por empresas com características societárias diferentes, como empresas de capital aberto, de capital fechado e as subsidiárias, poderiam ter sido feitos isoladamente para cada grupo, apesar da inclusão de variáveis de controle no estudo. Maydew (2000) elogia o uso do modelo de Ohlson para estimar o valor pré-aquisição de mercado de empresas sem capital aberto, uma metodologia que, segundo ele, deveria ser adotada por futuros pesquisadores nessa área.

Em abordagem de natureza um pouco diversa, porém com resultados auspiciosos, outros estudos verificam em que medida as mudanças tributárias se refletem diretamente sobre o preço de ativos. Guenther (1994) examina a alteração nos preços (mais precisamente, nos retornos) de títulos do Tesouro americano em resposta à redução das alíquotas de imposto. Títulos do Tesouro americano não fazem pagamentos de juros periodicamente (zero coupon rate) e por isso são vendidos descontados. Ao investidor é prometida uma taxa de retorno fixa 
até o final da vida do título, conhecida como yield to maturity, YTM. O retorno do investidor é dado pelo quociente entre (i) a diferença entre o valor de face e o valor presente e (ii) valor de face do título ${ }^{16}$. Pelas regras americanas, a receita de juros proveniente do desconto a valor presente desse tipo de título não é tributada até que a maturidade ocorra. Então, dois títulos do Tesouro americano que maturem em datas próximas, um no mês de dezembro, por exemplo, e o outro em janeiro do ano seguinte, produzirão juros que serão tributados diferentemente se entre as duas maturidades ocorrer alguma alteração nas regras de tributação dos juros prometidos pelos dois títulos. Guenther (1994) utilizou essa lógica para pesquisar os efeitos das reduções da alíquota incidente sobre os juros proporcionados por títulos do Tesouro afetados pelo ERTA, Economic Recovery Tax Act, de 1981, e pelo TRA, Tax Reform Act, de 1986. Como a teoria econômica prevê que, em equilíbrio e ceteris paribus, o retorno antes dos impostos difere para ativos de mesmo risco sujeitos a diferentes condições de tributação, Guenther (1994) obteve evidências da ocorrência de uma significativa redução nos retornos antes dos impostos coincidente com a redução de alíquota determinada pelos dois atos, fornecendo indícios consistentes com a existência da tributação implícita.

Outras pesquisas examinam a relação entre retorno antes dos impostos e o nível de impostos explícitos. Por exemplo, Wilkie (1992) documenta uma consistente e estatisticamente significativa relação inversa entre subsídios tributários e taxas de retorno antes do imposto. A obtenção de subsídios tributários pode ser vista como uma redução dos tributos pagos explicitamente em investimentos favorecidos tributariamente. Wilkie, no entanto, alerta que mercados menos que perfeitos podem impedir ou reduzir a ocorrência de tributos implícitos ao permitir que empresas obtenham chances de praticar arbitragens tributárias. O alerta de Wilkie pode ser de grande utilidade para a implementação de políticas públicas ou tributárias, pois a violação do pressuposto de que a carga tributária total (implícita e explícita) é a mesma entre contribuintes pode provocar desigualdades competitivas importantes.

Callihan e White (1999) estendem o trabalho de Wilkie (1992) e traçam um histórico de pesquisas que evidenciam que, quando os mercados não são perfeitamente competitivos, reduções (ou aumentos) na tributação implícita podem não ser compensadas na mesma

\footnotetext{
${ }^{16}$ Por exemplo, suponha-se um Treasure Bill de 10 anos, com YTM de 7\%. Em 10 anos (maturidade), com capitalização semestral, o valor desse título no resgate (maturidade) será $\$ 1.000$. O valor corrente desse título seria aproximadamente de $\$ 503$, obtido pelo valor presente do valor de $\$ 1.000$ descontado à taxa de $7 \%$ ao ano capitalizada semestralmente (taxa efetiva de 7,12\% a.a.).
} 
proporção por aumentos (ou reduções) na tributação implícita. Os autores citam como exemplo potencial dessa situação o caso da indústria bélica norte-americana. Antes de 1987, empresas do ramo de armamentos podiam utilizar o método contábil conhecido por completed contract method também para fins tributários. Com isso, permitiam-se grandes volumes de diferimento de lucro e, conseqüentemente, uma economia expressiva no pagamento de imposto explícito. Nessas condições, esperava-se que essas indústrias pagassem quantias significativas de impostos implícitos, por via da redução dos preços cobrados pelo Departamento de Defesa (ou, em última instância, cobrados de toda a sociedade). Não obstante, se o mercado de equipamentos de defesa não era perfeitamente competitivo, os fabricantes de armamentos poderiam ter captado parte da economia dos tributos implícitos em prol deles próprios. Callihan e White (1999) comentam que a estrutura de mercado pode ter aberto a oportunidade de reduzir a carga tributária total através da maior habilidade de não repassar parte dos ganhos com os tributos implícitos para os preços dos produtos ofertados. A conclusão do estudo é de que há indícios da existência de uma relação inversa entre o poder de mercado de uma empresa e os seus níveis de pagamento de tributos implícitos.

Scholes et al (op. cit., p. 132) apontam que informações detalhadas sobre a propriedade das ações são mais difíceis de serem obtidas, por isso a maioria dos pesquisadores opta por testar a existência de tributação implícita em vez de tentar comprovar a existência de clientela tributária. Um estudo, contudo, que examina diretamente a clientela é o de Dhaliwal, Erickson e Trezevant (1999). Eles descobriram que, quando uma empresa que tradicionalmente não pagava dividendos passa a distribuí-los, a sua base de acionistas migra dos indivíduos, sobre os quais a tributação dos dividendos é desvantajosa, para alguns tipos de investidores corporativos que possuem tributação mais vantajosa dos dividendos, como é o caso dos fundos de pensão. Os resultados do estudo são consistentes com a existência de clientela tributária formada em resposta ao grau de tributação de dividendos. 


\title{
3 SELEÇÃO DA AMOSTRA
}

A seleção do(s) título(s) é crucial para que se comprove empiricamente a existência da tributação implícita. A medida provisória que concedeu a isenção ao investidor estrangeiro não beneficiava um título público específico. A MP no 281/2006, publicada em 16 de fevereiro de 2006, reduziu a zero a alíquota de imposto de renda incidente sobre os rendimentos produzidos por título público federal, qualquer que fosse ele, adquirido por estrangeiros.

Em estudo da Andima, Associação Nacional das Instituições do Mercado Financeiro, (2007, p. 59), apontava-se o aumento significativo do investimento estrangeiro no Brasil em resposta à MP nº 281/2006:

\begin{abstract}
A grande liquidez do mercado internacional de crédito nos últimos anos alterou de maneira expressiva o padrão de investimento estrangeiro nos mercados emergentes de dívidas públicas e acionário. A participação desses investidores no mercado doméstico de títulos tem sido um fator de impulso para que se consolide um novo perfil de financiamento, geralmente através de um aumento do prazo em posições prefixadas e indexadas.

Nesse aspecto, a quebra de paradigma no Brasil se deu com a isenção do Imposto de Renda para os investidores não-residentes, em fevereiro de 2006. A participação dos investimentos estrangeiros no mercado de renda fixa subiu de $7,8 \%$ para $21 \%$ entre fevereiro/06 e julho/07. A consolidação do ambiente macroeconômico brasileiro e a provável classificação do país para investment grade cria perspectivas positivas para que se aumente ainda mais a participação destes investidores no mercado financeiro nacional.
\end{abstract}

O estudo, contudo, não indicava qual título especificamente foi escolhido pelo estrangeiro. Esperava-se que essa informação estivesse disponível nos sites da STN, Secretaria do Tesouro Nacional, ou do Banco Central. Salvo melhor juízo, essa informação não é encontrada em nenhum website pesquisado. Tentou-se contato com os dois órgãos, mas não houve sucesso ${ }^{17}$. Encontraram-se, ainda assim, algumas evidências de que os investidores estrangeiros escolheram se posicionar nas NTN-B, Notas do Tesouro Nacional-série B, títulos pós-fixados de longo prazo.

\footnotetext{
${ }^{17}$ Foram enviados e-mails para a Secretaria do Tesouro Nacional e o Banco Central solicitando que fossem informados quais títulos teriam sido mais demandados pelo investidor estrangeiro no ano de 2006, haja vista que essa informação, salvo melhor juízo, não era encontrada em nenhum site público. As respostas dos dois órgãos foram recebidas por e-mail. Curiosamente, a Secretaria do Tesouro Nacional informou que esses dados seriam encontrados no Banco Central; já o Banco Central informou que o solicitado seria encontrado na Secretaria do Tesouro Nacional.
} 
O estoque da DPMFi, dívida pública mobiliária federal interna, no ano de 2006, excluídos os títulos da dívida securitizada e os títulos da dívida agrária, estava fortemente concentrado em LFT, Letras Financeiras do Tesouro, LTN, Letras do Tesouro Nacional, NTN-B e NTN-C. Como se pode acompanhar abaixo, os quatro títulos representavam quase a integralidade da dívida pública interna:

Tabela 5 - composição percentual da DPMFi, por títulos sob responsabilidade da Secretaria do Tesouro Nacional, ano 2006.

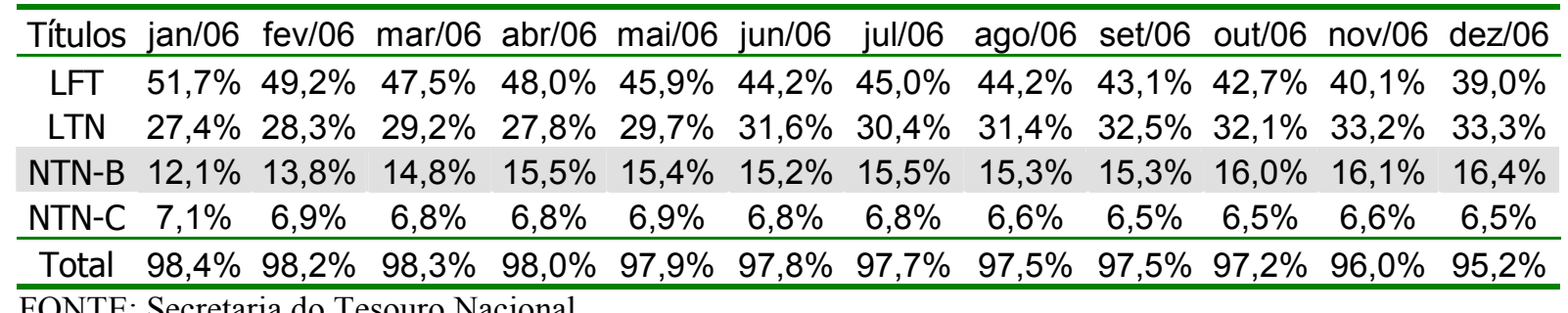

FONTE: Secretaria do Tesouro Nacional

A NTN-B e a LTN foram os únicos títulos que apresentaram um crescimento consistente ao longo de 2006. O crescimento da participação da LTN foi da ordem de $21,5 \%$, ao passo que a NTN-B cresceu cerca de 35,5\%.

$\mathrm{Na}$ falta de informação mais precisa, recorreu-se a outras fontes. O Relatório Anual da Dívida Pública Federal de 2006, publicado pela STN, descreve o aumento da participação estrangeira na Dívida Pública em resposta à MP no 281/2006:

\begin{abstract}
A participação estrangeira no mercado doméstico apresentou uma elevação significativa após a edição da Medida Provisória. A média do estoque aplicado em títulos públicos por investidores estrangeiros, que foi de $\mathrm{R} \$ 2,7$ bilhões entre janeiro de 2005 e fevereiro de 2006, passou para R\$ 10,7 bilhões entre março e dezembro deste ano. Ressalta-se que o montante aplicado pelos investidores estrangeiros em Fundos de Investimento Financeiro (FIF), que são compostos em sua quase totalidade por títulos públicos, também apresentou crescimento considerável após a edição da medida, mantendo uma média de $\mathrm{R} \$ 13,3$ bilhões entre março e dezembro deste ano, frente a $\mathrm{R} \$ 5,0$ bilhões no mesmo período do ano passado.
\end{abstract}

Ao final de 2006, ainda de acordo com o Relatório Anual Dívida Pública Federal, a parcela da dívida interna de propriedade de investidores estrangeiros somava $2,64 \%$ do total, um aumento da participação estrangeira de cerca de $283 \%$ em relação ao final de 2005 , quando os investidores estrangeiros detinham apenas $0,69 \%$ da dívida interna brasileira. 
Entre as diretrizes traçadas pela Secretaria do Tesouro Nacional para 2006, divulgadas no Plano Anual de Financiamento, estava a intenção de alongar o prazo médio da Dívida Pública Federal. Um dos pressupostos adotados pela STN foi o incremento do volume emitido de títulos referenciados a índices de preços, com ênfase nas NTN-B, Notas do Tesouro Nacional - série B.

Várias reportagens ligavam a isenção de imposto de renda da MP n 281/2006 à compra das NTN-B por investidores estrangeiros. O Correio Brasiliense noticiava em 25/04/2006:

\begin{abstract}
A isenção do Imposto de Renda para os investidores estrangeiros comprarem os títulos da dívida pública federal, implantada por Medida Provisória pelo governo, começa a trazer resultados. Com a publicação da MP 281, os estrangeiros passaram a comprar mais papéis brasileiros e, com isso, sua participação subiu de algo abaixo de $5 \%$ para $20 \%$ (média dos meses de fevereiro e março) nas novas emissões dos papéis. Segundo o coordenador da Dívida Pública do Tesouro Nacional, Ronnie Tavares, o maior interesse deve facilitar o propósito do tesouro de alongar sua dívida e facilitar sua administração, hoje o principal problema econômico do país. Os investidores estrangeiros adquiriram $57 \%$ dos títulos vendidos nos leilões primários com prazo acima de 10 anos e $33 \%$ dos papéis com vencimentos entre três e 10 anos, conforme números divulgados ontem pelo Tesouro Nacional. Para os títulos com prazo de vencimento até três anos a compra foi de 7\%. Além disso, o aumento da presença desses investidores contribui para a queda das taxas de juros. A taxa da NTN-B, com prazo de vencimento em 2045 , caiu de $8,54 \%$ em janeiro para $7,50 \%$ em março.
\end{abstract}

A edição de 25/6/2006 do Valor Econômico noticiou a força dos investidores estrangeiros como detentores das NTN-B no período posterior à MP no 281/2006:

Revoltados com as dificuldades encontradas na venda de NTN-B - títulos públicos de longo prazo indexados ao IPCA, que desde fevereiro gozam de isenção de IR ao capital externo -, fundos estrangeiros promoveram ontem um ataque especulativo contra o real. Com isso, a moeda nacional desvalorizou-se $4,5 \%$, muito mais que as de outros mercados emergentes afetados pelo aumento da aversão mundial ao risco. A lira turca perdeu $3,4 \%$; o peso colombiano, $1,82 \%$; e o rublo russo, $0,04 \%$, enquanto o peso mexicano valorizou-se $1,11 \%$.

Ao contrário de outros segmentos, em que as rotas de fuga estão escancaradas, a saída das NTN-B mostra-se complicada: há pouca liquidez e os compradores exigem juros muito altos. A taxa subiu de 7,5\% no início do ano para a faixa entre $10 \%$ e $12 \%$. Aceitar essas condições implica perda de $20 \%$ a $30 \%$ do principal aplicado pelo fundo.

Cativos do papel, os especuladores decidiram retaliar ontem, um dia de calmaria em Wall Street, e provocaram desvalorização do real e alta dos juros futuros. O dólar subiu 4,71\%, para $\mathrm{R} \$ 2,40$, maior cotação desde agosto de 2005. Só em maio, o ganho chega a 14,94\%. O CDI para janeiro de 2008 avançou de $15,48 \%$ para $16,65 \%$. A alta distorceu a curva dos juros e tirou a confiabilidade das projeções para as próximas decisões do Copom.

A retaliação visava, segundo analistas, pressionar o governo de forma a obter ajuda para a saída do capital. O Tesouro veio em socorro dos investidores, recomprando R $\$ 1,753$ bilhão em papéis e criando parâmetros de preço para um mercado que, sem referências, estava travado. Foi marcado um leilão nos mesmos moldes para hoje. A operação de socorro irritou gestores nacionais, cujas perdas foram muito pesadas em posições "vendidas" em dólar e prefixadas em DI futuro, as mais atacadas pelos estrangeiros. 
A atuação do Tesouro Nacional nesse momento de volatilidade está descrita no Plano Anual de Financiamento de 2006 da Dívida Pública Federal. A fim de dar liquidez às NTN-B, o Tesouro Nacional realizou, nos dias 24, 25 e 26 de maio de 2006, leilões simultâneos de compra e venda de NTN-B e assim justificou a sua atuação:

- O Tesouro Nacional vê o investidor estrangeiro como um importante parceiro para a melhoria e alongamento do perfil da dívida pública;

- O objetivo desta operação foi fornecer parâmetros de preços para o mercado, que no momento apresentava-se volátil;

- Esta estratégia condiz com o comportamento histórico do Tesouro, que sempre atuou em momentos de volatilidade como um agente estabilizador do mercado;

- Os resultados dos leilões, em termos de montante comprado e vendido, confirma que o Tesouro teve sucesso em estabilizar o mercado.

O Global Financial Stability Report, divulgado pelo Fundo Monetário Internacional em 2007, faz menção a um aumento de preço das NTN-B provocado pelo investidor externo em resposta à isenção tributária introduzida pela MP nº 281/2006:

Desde o meio do ano de 2005, o governo brasileiro tenta reduzir a sua vulnerabilidade externa reduzindo o seu débito externo. Investidores estrangeiros que pretendam alocar seus recursos no Brasil, portanto, têm que se refugiar no mercado financeiro doméstico e, em particular, nos títulos denominados na moeda brasileira. Estimulados por uma isenção concedida em fevereiro de 2006 aos títulos adquiridos por estrangeiros, instituições financeiras estrangeiras investiram um total de 52 bilhões de reais em títulos públicos brasileiros até março de 2006, 47\% a mais que em março de 2005. A NTN-B, título de longo prazo indexado à inflação, foi especialmente popular. Os investimentos em NTN-B pelas instituições financeiras estrangeiras representaram cerca de $10 \%$ do total de emissões até abril de 2006. À medida que as instituições expandiram sua participação nas NTN-B, os preços desses títulos aumentaram até $18 \%$ no mês seguinte à isenção tributária. ${ }^{18}$ (tradução livre)

A existência da tributação implícita será, portanto, verificada utilizando-se as NTN-B negociadas no mercado secundário na época da entrada em vigor da MP $n^{\circ}$ 281/2006. A confirmação quanto ao acerto das pretensões do governo brasileiro ao emitir a MP - alongar o perfil da dívida e reduzir os juros - só poderá ser ratificada futuramente. No entanto, a comprovação da existência da tributação implícita é uma evidência de que o governo conseguirá reduzir o custo futuro da sua dívida, uma vez que a tributação implícita significa

\footnotetext{
${ }^{18}$ Since mid-2005, the Brazilian government has tried to reduce the country's external vulnerability by retiring its external debt. Foreign investors seeking exposure to Brazil therefore had to resort to the domestic financial markets, and in particular local-currency denominated government bonds. Encouraged by a tax exemption granted on foreign investment in local bond markets in February 2006, foreign financial institutions had allocated a cumulative $\mathrm{R} \$ 52$ billion to local-currency denominated government bonds by end-March 2006, 47 percent higher than in March 2005. The long-dated inflation-linked government bonds-Series B National Treasury Notes (NTN-B) — were especially popular. Foreign financial institutions' holdings of NTN-B bonds represented about 10 percent of the total issue by April 2006. As those institutions expanded their participation in the NTN-B bond market, bond prices increased by 18 percent in the month following the tax exemption.
} 
que o investidor que adquire o ativo favorecido tributariamente aceita também um retorno inferior ao retorno de um ativo sem favorecimento.

Ao deixar o investidor estrangeiro livre para alocar seus recursos, o governo aparentemente agiu de forma inteligente, pois confiou no comportamento racional dos agentes de mercado. Até onde se pode visualizar, o investidor estrangeiro decidiu-se, principalmente, pela NTN-B, título de longo prazo e de excelente remuneração, em especial se se tiver em conta que os juros tendem a baixar futuramente, como tem mostrado a experiência de outros países e mesmo do Brasil.

O aumento significativo do preço da NTN-B reportado pelo Fundo Monetário Internacional pode ser uma evidência de que o investidor estrangeiro sofreu uma tributação implícita. A magnitude da tributação implícita sofrida dependerá de se o investidor marginal nas NTN-B era o investidor brasileiro. Em última instância, o grau de tributação implícita é, sobretudo, uma questão empírica que será aqui investigada. 


\section{ASPECTOS METODOLÓGICOS}

Para comprovação empírica da tributação implícita no Brasil, será verificado o efeito da isenção concedida pela MP n ${ }^{\circ}$ 281/2006 sobre os retornos das NTN-B. O principal objetivo desta parte empírica é verificar se a isenção introduzida pela medida provisória provocou uma perda significativa de retorno pré-imposto das NTN-B em relação ao período anterior à vigência da isenção.

Dado que a tributação implícita necessita de uma comparação de retornos pré-imposto de dois ativos de risco semelhante, porém diferentemente tributados, tem-se que o ativo favoravelmente tributado será o título público afetado pela isenção, comparado a ele próprio em períodos anteriores à isenção, quando ele não gozava de benefícios fiscais. Assim como no estudo de Guenther (1994), a idéia é comparar o mesmo título antes e depois da mudança legislativa. Com isso, a diferença de percepção de risco no carregamento de ativos diferentes fica mitigada, o que dá maior segurança de que uma redução de retorno bruto ocorreria por outras razões que não as diferenças de risco associadas a investimentos em ativos diversos.

O que se procurará investigar, portanto, é a existência de uma redução estatisticamente significativa, em determinado ponto do tempo (em torno da data do início da vigência da MP

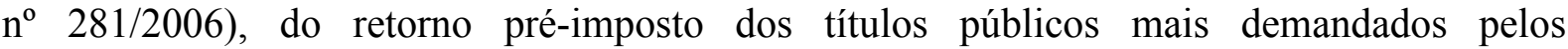
estrangeiros. A técnica estatística a ser utilizada será a análise de séries temporais, uma vez que os dados analisados são os retornos de um mesmo título ao longo do tempo.

Como exposto na seção 3, há indicativos de que a NTN-B foi o título mais fortemente demandado pelo investidor estrangeiro. Por isso, espera-se que o retorno antes dos impostos desse título tenha se reduzido a partir de algum período próximo ao início da vigência da MP. Os investidores estrangeiros se posicionaram, de acordo com as notícias, nas NTN-B de vencimentos mais longos. Assim sendo, os testes empíricos serão realizados sobre as NTN-B com vencimentos em 2045, 2033 e 2024. O comportamento dos retornos desses papéis é bastante semelhante, como comprovam os gráficos com as séries temporais dos seus retornos diários: 

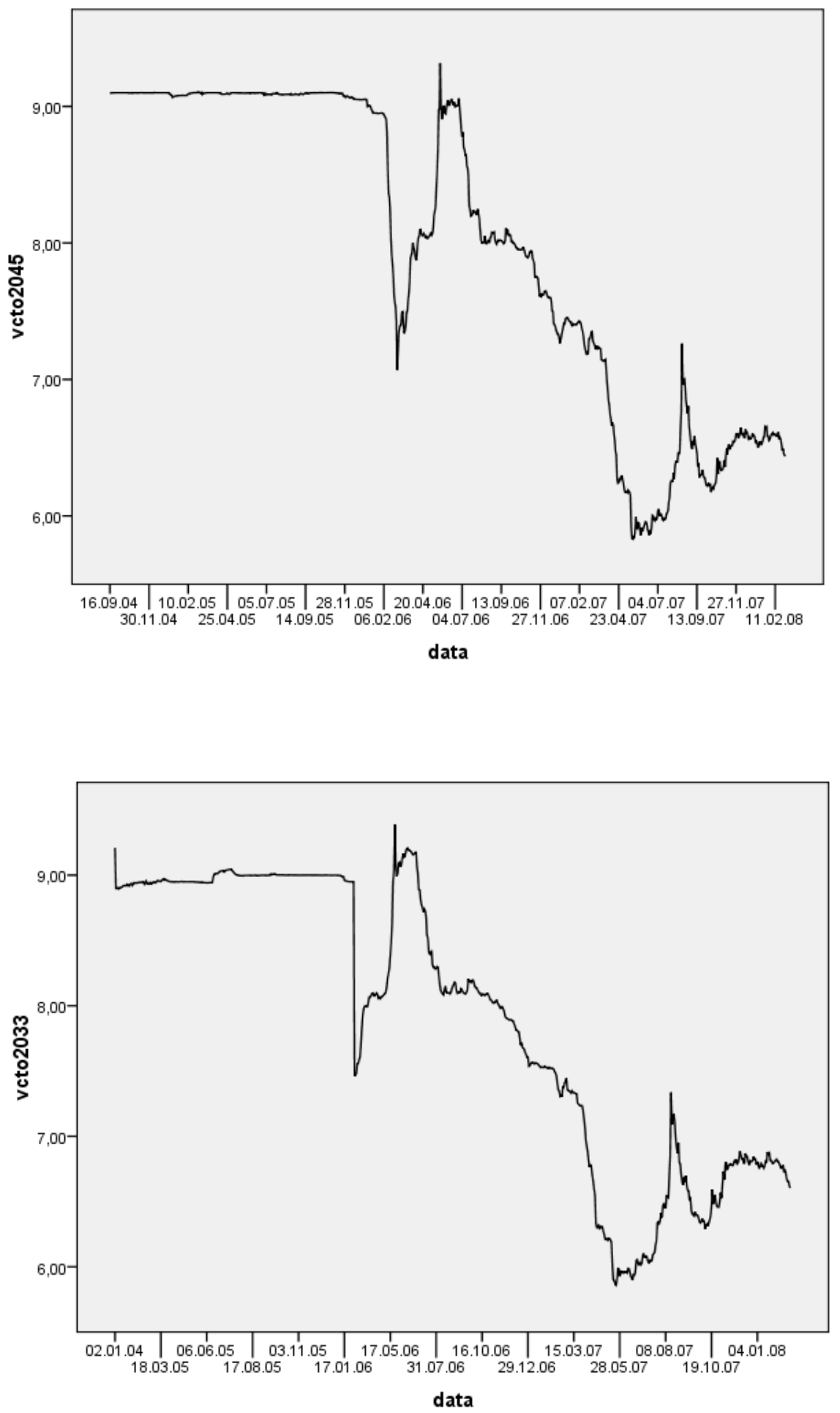


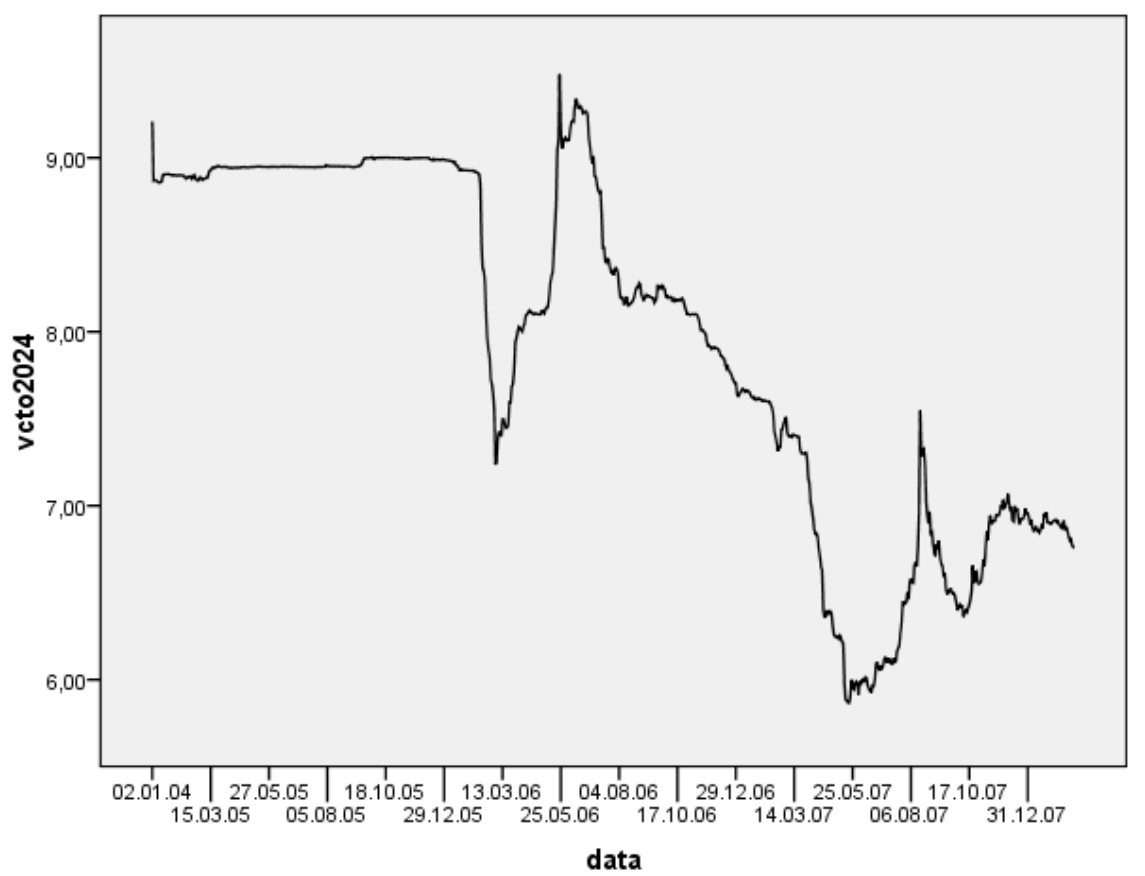

Gráfico 3 - comportamento das séries diárias dos retornos das NTN-B ${ }_{2045}$, NTN-B ${ }_{2033}$ e NTN-B ${ }_{2024}$ •

Dada a evidente semelhança no comportamento dos retornos das NTN-B de longo prazo, toda a metodologia estatística utilizada para comprovação da tributação implícita sofrida pelas NTN-B longas será, passo a passo, detalhada apenas para a NTN-B de vencimento em 2045, mas os resultados para as demais NTN-B serão também apresentados posteriormente.

Antes do detalhamento da metodologia estatística, contudo, serão apresentados os principais conceitos, definições e características correlatos à NTN-B.

\subsection{Metodologia de Precificação de Títulos Públicos}

Os retornos das NTN-B foram obtidos da Andima. Os cálculos e a metodologia de precificação dos títulos públicos federais encontram-se pormenorizados no Anexo VI do COM, Código Operacional do Mercado, um manual desenvolvido pela Andima. Os principais pontos do COM estão parcialmente reproduzidos abaixo, entremeados por comentários que fazem a ligação entre as explicações contidas no Código Operacional do Mercado e os conceitos contidos na presente tese. 


\subsubsection{Histórico e procedimentos sobre a precificação dos títulos públicos}

O início do trabalho de precificação dos ativos financeiros começou em novembro de 1999, quando o Banco Central e o Tesouro Nacional delegaram à Andima a atribuição de divulgar parâmetros de taxas para títulos públicos federais negociados no mercado secundário.

O passo seguinte foi a montagem de uma amostra de informantes que ficou responsável por repassar diariamente as taxas para a Associação e que foi, originalmente, constituída pelas instituições financeiras mais ativas no mercado secundário de títulos públicos federais. Além dos dealers de mercado aberto, foram indicadas pelo Banco Central outras instituições que também se destacavam naquele segmento. Posteriormente, foram incorporados à amostra gestores e intermediários financeiros especializados na negociação de títulos públicos: esse conjunto de instituições forma os price makers da Andima.

No Brasil, apesar de o registro dos negócios ser obrigatoriamente efetivado em centrais depositárias, as características dos títulos e as distribuições das emissões do segmento público ainda geram baixo volume de negócios no mercado secundário, que são concentrados em alguns poucos vencimentos (vértices). Em termos metodológicos, a melhor informação para a precificação seria aquela que tivesse como origem as próprias negociações realizadas entre os participantes do mercado e registradas em sistemas eletrônicos. A realidade do mercado secundário brasileiro, entretanto, afasta, pelo menos temporariamente, essa possibilidade.

No caso dos títulos públicos, as informações do universo das operações registradas no SELIC, Serviço Especial de Liquidação e Custódia, divulgadas pelo Banco Central com defasagem de um dia, revelam que boa parte dos vencimentos dos títulos em mercado (incluindo-se, apenas, as LTN, NTN-D, NBC-E, LFT, NTN-C, NTN-B e NTN-F) registra número de negócios extremamente reduzido diariamente e, freqüentemente, não contabiliza um único negócio. A solução metodológica encontrada pela Andima para o problema da baixa liquidez foi a criação de uma amostra de informantes - conforme descrito acima - que passam diariamente para a Associação informações de duas naturezas distintas: Taxas Máximas e Mínimas, que representam os spreads praticados e/ou observados ao longo do dia; e Taxas Indicativas, que se referem às taxas avaliadas pela instituição como preço justo de negócio para cada 
vencimento, de acordo com as curvas individuais, independentemente de ter ocorrido negócio com o papel.

Na prática, como o número de negócios é pequeno e disperso entre os diversos vencimentos, as informações de Taxas Máximas e Mínimas - que refletiriam transações ou spreads abertos ao longo do dia - que chegam à Andima não são suficientes para que possam ser apuradas taxas para todos os papéis e seus respectivos vencimentos. Já para as Taxas Indicativas, o volume de informações enviadas e a metodologia de cálculo das taxas médias fazem com que a maior parte dos vencimentos seja precificada. Embora esses preços sejam sintéticos, no sentido de não refletirem negócios concretamente realizados, a comparação ex post com as taxas efetivamente praticadas revela uma forte aderência entre ambas as informações, sobretudo para aqueles vencimentos em que o número de registros no SELIC é mais significativo.

\subsubsection{Metodologia de cálculo das taxas de retorno}

As informações são enviadas para a Andima na forma de taxas (ANDIMA, 2008, p. 31):

As informações devem ser enviadas em forma de taxa, sendo que o sistema foi configurado para que, no caso de títulos prefixados e indexados a índices de preços (IGP-M e IPCA), a expressão seja na forma anual, base 252 dias úteis; para títulos cambiais, na forma de taxa nominal anual, convenção 30/360; para pós-fixados, rentabilidade em taxa efetiva ao ano, base 252 dias úteis; e para os cambiais "swapados", em percentual do DI.

$\mathrm{Na}$ terminologia adotada pela Andima, as taxas de retorno ${ }^{19}$ são chamadas de taxas indicativas. A Associação define taxas indicativas como (ANDIMA, 2008, p. 31):

Taxas avaliadas pela instituição como referência de preço justo de negócio para cada vencimento, de acordo com suas curvas individuais, independentemente de ter havido negócio ou, mesmo, que o título tenha sido cotado no mercado secundário no decorrer do dia. Estas últimas devem ser calculadas após o fechamento do mercado.

No processo de cálculo, eliminam-se os possíveis erros e aplicam-se filtros estatísticos, após os quais se chega à taxa indicativa. Há dois filtros estatísticos que asseguram que as taxas, mesmo em momentos de grande volatilidade, mantenham-se dentro de um intervalo de segurança.

\footnotetext{
${ }^{19}$ Taxa de retorno e taxa indicativa (ou "taxa média"), para fins deste estudo, são tidas como expressões sinônimas. No entanto, "taxa indicativa" (ou "taxa média") é utilizada apenas na apresentação do Código de Operação do Mercado. Outra expressão comumente utilizada pelo mercado para designar taxa de retorno é o termo em inglês yield to maturity.
} 
O primeiro filtro permite obter taxas a termo, para períodos intermediários, mais suaves do que as que são obtidas pelo procedimento de capitalização das próprias taxas a termo. Esse filtro elimina as observações cujo desvio absoluto, em relação à mediana, exceder um desvio apurado através da multiplicação de um coeficiente de variação padrão, $a$, pela mediana das taxas recebidas no dia, desde que esse desvio não seja menor do que um valor absoluto mínimo, $b$, previamente determinado, o qual deverá variar de acordo com as magnitudes absolutas das taxas praticadas em cada conjuntura. Assim, $d r_{t}^{i}=r_{t}-M d_{r}$, onde $d r_{t}^{i}$ é o desvio absoluto da observação $i$, da taxa $r$, no dia $t$; $M d$ é a mediana dos retornos.

Eliminam-se, então, as observações $i$ que tiverem $\left|d r_{t}^{i}\right|>\left\{\left|a \times M d_{t}\right|, b\right\}$, onde $a$ é o coeficiente de variação padrão e $b$ é o valor mínimo absoluto. O valor do parâmetro $a$ está estabelecido em $10 \%$ e o parâmetro $b$ é fixado em 0,5 ponto percentual, podendo ser alterado todas as vezes em que os testes revelarem alguma mudança significativa no padrão de precificação de um determinado ativo.

As observações validadas pelo primeiro filtro sujeitam-se aos critérios do segundo filtro, pelo qual são eliminadas as observações que estiverem fora de um determinado intervalo de confiança. Portanto, $(-t \sigma / \sqrt{n})<\left|d r_{t}^{i}\right|<(t \sigma / \sqrt{n})$, onde $t$ é o parâmetro da distribuição $t$ de Student, $n$ é o número de retornos e $\sigma$ é o desvio-padrão dos retornos.

O intervalo de confiança dependerá da volatilidade das taxas observadas diariamente para cada vencimento. Assim, se a volatilidade da taxa de juros do dia for maior que uma vez e meia a média da volatilidade dos três dias anteriores, então é aceitável supor que a volatilidade das taxas fornecidas deve aumentar. Nesse caso, o intervalo de validação das taxas será menos conservador, ou seja, serão utilizados os parâmetros para a distribuição $t$ que geram um intervalo de $97,5 \%$ de grau de confiança. Inversamente, se a volatilidade da taxa de juros do dia diminuir, aumenta-se o rigor do filtro, usando-se os parâmetros para a distribuição $t$ que geram um intervalo de $95 \%$ de grau de confiança.

Por fim, as observações validadas pelos dois filtros anteriores são submetidas a um terceiro filtro que é montado a partir de informações de mercados derivativos que sejam passíveis de arbitragem com o mercado de títulos públicos federais. A hipótese básica é a de que, em 
condições normais de mercado, a curva de títulos públicos e a curva dos mercados derivativos devem apresentar comportamentos similares, dado um nível de spread esperado entre esses mercados. Assim, a comparação dessas curvas pode funcionar como um mecanismo importante de avaliação da consistência das Taxas Indicativas apuradas pela Andima para cada um dos títulos públicos precificados.

\subsubsection{Características da NTN-B}

A Nota do Tesouro Nacional - Série B representa um título referenciado na taxa de inflação medida pelo IPCA, Índice Nacional de Preços ao Consumidor Amplo, apurado e divulgado pelo IBGE, Instituto Brasileiro de Geografia e Estatística, com o pagamento de cupom semestral baseado em taxa a ser determinada na data de emissão ${ }^{20}$.

Na emissão, o Tesouro estabelece uma taxa de juros que será utilizada no cupom semestral a ser pago, de acordo com o critério de formação de calendário para o pagamento de cupom. A taxa de juros é expressa na forma efetiva anual, base 252 dias úteis. A título de exemplo, uma taxa de juros de cupom de $6 \%$ ao ano resulta em uma taxa efetiva semestral de $2,9563 \%^{21}$ e uma taxa de cupom de $12 \%$ ao ano resulta em uma taxa semestral de 5,83\%.

O preço da NTN-B é obtido pela relação entre o VNA, valor nominal atualizado, e a sua cotação, que é obtida pelo valor dos cupons semestrais trazidos a valor presente pela taxa yield to maturity do título. Essa taxa representa a forma como o título é negociado e é obtida através da taxa interna de retorno do fluxo de pagamentos do título. A taxa interna de retorno representa a taxa de juros que anula o valor presente líquido do fluxo do título.

A metodologia de cálculo da rentabilidade da NTN-B é explicada e exemplificada a seguir, supondo uma taxa de juros de $6 \%$ ao ano. Como a coleta de preços para cálculo do IPCA

\footnotetext{
${ }^{20}$ A referência à taxa de inflação é feita através do denominado Valor Nominal Atualizado, VNA, divulgado diariamente pelo Banco Central e representado pelo valor de $\mathrm{R} \$ 1.000,00$ na data base do título, corrigida mensalmente pelo índice de preço do IPCA. O valor do VNA da NTN -B é atualizado no primeiro dia útil posterior ao dia 15 do mês, utilizando a variação do IPCA observada e divulgada para o mês imediatamente anterior. A Lei Complementar $\mathrm{n}^{\circ} 101$, de 4 de maio de 2000, determinou que a data base de todos os títulos emitidos após o dia 01/07/2000 não fosse a data de emissão do título, mas o dia 01/07/2000.
}

${ }^{21} i_{\text {semestral efetiva }}=(1+0,06)^{0,5}-1=2,9563 \%$. 
situa-se, aproximadamente, do dia 15 do mês anterior a 15 do mês de referência, utiliza-se o IPCA projetado pelo mercado para atualizar o valor nominal da NTN-B, sendo assim:

$x=\frac{\left(\mathrm{n}^{\mathrm{o}} \text { de dias corridosentrea data de liquidaçãoe o dia } 15 \text { do mês atual }\right)}{\left(\mathrm{n}^{\mathrm{o}} \text { de dias corridosentre o dia } 15 \text { do mês seguintee o dia } 15 \text { do mês atual }\right)}$

$V N A^{*}=\mathrm{R} \$ 1.000 \mathrm{x}$ fator de variaçãodo IPCA entre15/07/2000e o dia 15 do mês atual $V N A=V N A^{*}\left(1+I P C A_{\text {projetado }}\right)^{x}$

$C O T A C ̧ \tilde{A} O=\left[\frac{(1,06)^{0,5}-1}{(1+T I R)^{D U_{1} / 252}}\right]+\left[\frac{(1,06)^{0,5}-1}{(1+T I R)^{D U_{2} / 252}}\right]+\cdots+\left[\frac{(1,06)^{0,5}-1}{(1+T I R)^{D U n / 252}}\right]+\left[\frac{1}{(1+T I R)^{D U n / 252}}\right]$

$P R E C ̧ O=\frac{V N A}{C O T A C ̧ \tilde{A O}}$

Onde:

PREÇO: preçode compra;

VNA: valornominalatualizadopela variaçãodo IPCA entre a data - base(15/07/2000) e a data da liquidaçãa

$\mathrm{DU}_{\mathrm{i}}$ : dias úteis entrea data de liquidação(inclusive) e a data de venciment do cupom(exclusive);

TIR (TAXA): taxa interna de retornoanualdo título;

COTAÇÃO: preçode venda divididopelo VNAda NTN - B na liquidação

Exemplo:

- Título: NTN-B 150806

- Data de compra: $12 / 09 / 2003$

- Data de liquidação: 15/09/2003

- Valor na data-base (15/07/2000): R\$1.000,00

- Data de vencimento: 15/08/2006

- $\quad$ TIR (TAXA): 10,79\%

Com as informações acima, pode-se calcular o preço de compra (PU) do título:

$\mathrm{VNA}=\mathrm{R} \$ 1.000 \mathrm{x}$ variação do IPCA entre 15/07/2000 e o dia 15 do mês atual;

$\mathrm{VNA}=\mathrm{R} \$ 1.000 \times(1,354492078)=\mathrm{R} \$ 1.354,492078$.

Tendo em vista que a data de liquidação é o dia 15/09/2003, não há necessidade de projeção do IPCA. 


\begin{tabular}{cccc}
\hline & Datas & Dias Úteis & Dias Úteis/252 \\
\hline Cotação & $15 / 9 / 2003$ & & \\
$1^{\circ}$ cupom 15/2/2004 & 108 & 0,428571429 \\
$2^{\circ}$ cupom 15/8/2004 & 233 & 0,924603175 \\
$3^{\circ}$ cupom 15/2/2005 & 358 & 1,420634921 \\
$4^{\circ}$ cupom 15/8/2005 & 484 & 1,920634921 \\
$5^{\circ}$ cupom 15/2/2006 & 612 & 2,428571429 \\
$6^{\circ}$ cupom 15/8/2006 & 735 & 2,916666667 \\
\hline
\end{tabular}

COTAÇ $\tilde{A} O=\left[\frac{(1,06)^{0,5}-1}{(1+0,1079)^{108 / 252}}\right]+\left[\frac{(1,06)^{0,5}-1}{(1+0,1079)^{233 / 252}}\right]+\left[\frac{(1,06)^{0,5}-1}{(1+0,1079)^{358 / 252}}\right]+\left[\frac{(1,06)^{0,5}-1}{(1+0,1079)^{484 / 252}}\right]$ $\left[\frac{(1,06)^{0,5}-1}{(1+0,1079)^{612 / 252}}\right]+\left[\frac{(1,06)^{0,5}-1}{(1+0,1079)^{735 / 252}}\right]+\left[\frac{1}{(1+0,1079)^{735 / 252}}\right]$

COTAÇÃO $=0,891662$

$P R E C ̧ O=\mathrm{R} \$ 1.354,492078 \times 0,891662=R \$ 1.207,74$

A relação $\operatorname{preço~}_{N T N-B}=(V N A /$ cotação $)$ repete algebricamente o que ilustra o Gráfico 2. Existe uma relação inversa entre preço e cotação, isto é, em última instância, preço e taxa de retorno possuem uma correlação inversa. Naquele gráfico, o aumento da demanda geraria um aumento de preço e, conseqüentemente, uma redução do retorno.

Ao longo desta tese, tem-se repetido que a tributação implícita é a perda de retorno préimposto sofrida por ativos favorecidos tributariamente. Pois bem, a base da pesquisa são exatamente as taxas internas de retorno informadas diariamente (dias úteis) pelos colaboradores da Andima: a taxa interna de retorno é precisamente o retorno pré-imposto das NTN-B.

Note-se que nos componentes formadores do preço da NTN-B não há qualquer menção a imposto de renda. A taxa informada pelos agentes de mercado é a taxa bruta; aliás, nem poderia deixar de ser assim, uma vez que a única taxa que de fato é comparável entre investidores é a taxa de retorno pré-imposto. Basta imaginar que, para um investidor imune, por exemplo, a taxa de retorno pré é igual à pós-imposto, enquanto um investidor sem imunidade ou isenção tem o retorno pós-retorno menor que o retorno bruto. Essa diferença é tão maior quanto maior for a alíquota marginal do imposto de cada investidor. 


\subsection{Método Aplicado}

A análise de séries temporais é utilizada como ferramental econométrico básico, auxiliada por uma técnica conhecida como análise de intervenção, pela qual se avalia se "a trajetória de uma série de tempo é substancialmente alterada por medidas tomadas por agentes econômicos, em especial pelo governo, ou por eventos excepcionais" (VASCONCELLOS e ALVES, 2000, p. 240).

A análise de intervenção tem sido utilizada em estudos de impacto da introdução de novas leis de trânsito; o impacto do aumento do rigor e da concessão de porte de armas; o impacto da qualidade do ar decorrente de novas leis ambientais, entre outros (VANDAELE, 1983, p. 334). A análise de intervenção utiliza modelagens tipicamente construídas como um meio de se verificar quantitativamente o impacto de um evento sobre um processo estocástico (VANDAELE, op. cit., p. 258).

\subsubsection{Método de Box-Jenkins}

O entendimento da análise de intervenção pressupõe a compreensão do pilar sobre o qual ela repousa: a metodologia univariada (que inclui apenas uma série temporal) de Box-Jenkins para séries de tempo. Essa metodologia consiste na extração de movimentos preditivos a partir de dados observáveis. Basicamente, as séries de tempo são separadas em vários componentes, às vezes chamados de filtros (VANDAELE, op. cit., p. 9). A abordagem de Box-Jenkins faz uso de três filtros lineares: o auto-regressivo, o de integração e o de médias móveis.

O esquema abaixo ilustra como uma série de dados temporais, $z_{t}$, é transformada pelos filtros conhecidos como ARIMA ( $\mathrm{AR}=$ =auto-regressivo; $\mathrm{I}=$ integração; MA=média móvel, do inglês "moving average").

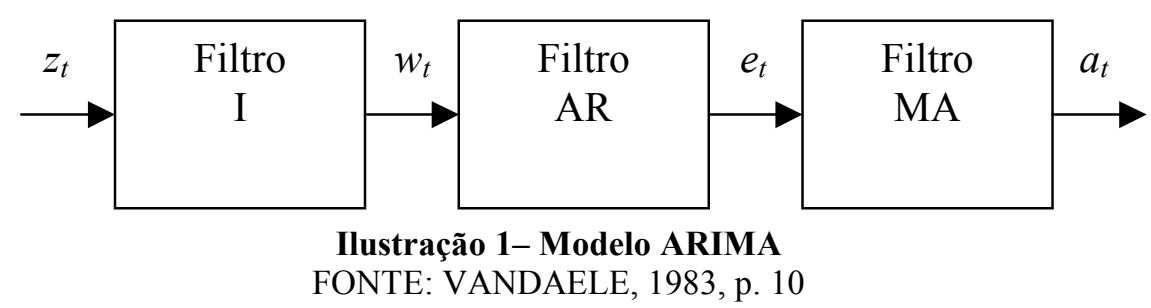


Depois da aplicação do filtro de integração (I) sobre os dados originais, obtém-se uma série filtrada, $w_{t}$, a qual é, por sua vez, processada pelo filtro auto-regressivo (AR), resultando na série intermediária $e_{t}$. Por fim, a passagem de $e_{t}$ pelo filtro MA gera um ruído randômico (random noise), $a_{t}$, que é imprevisível. Todo o processo de filtragem, pois, isola (ou filtra) o que é explicável (ou previsível) daquilo que não possui um comportamento explicável, um ruído randômico.

O método de Box-Jenkins proporciona o entendimento de quais filtros são mais apropriados para identificar e estimar o modelo e os parâmetros representativos de uma série temporal. Uma série de tempo pode conter os três filtros ou apenas um subconjunto deles; a escolha da melhor alternativa recairá sobre aquele modelo que for o mais parcimonioso (em número de variáveis explicativas) possível, sem que se perca de vista uma boa representatividade descritiva (e, portanto, preditiva) da série em estudo.

Essencialmente, o que se pretende obter aqui é um modelo que descreva adequadamente o comportamento da série de retornos. Segundo Vasconcellos e Alves (op. cit., p. 201), existe uma abordagem que considera as séries de tempo como integralmente geradas por um mecanismo aleatório, denominado processo estocástico: em cada instante de tempo $t$, existe uma família de valores que a série pode assumir, aos quais estão associadas probabilidades de ocorrência. Isso pode ser traduzido pela figura abaixo:

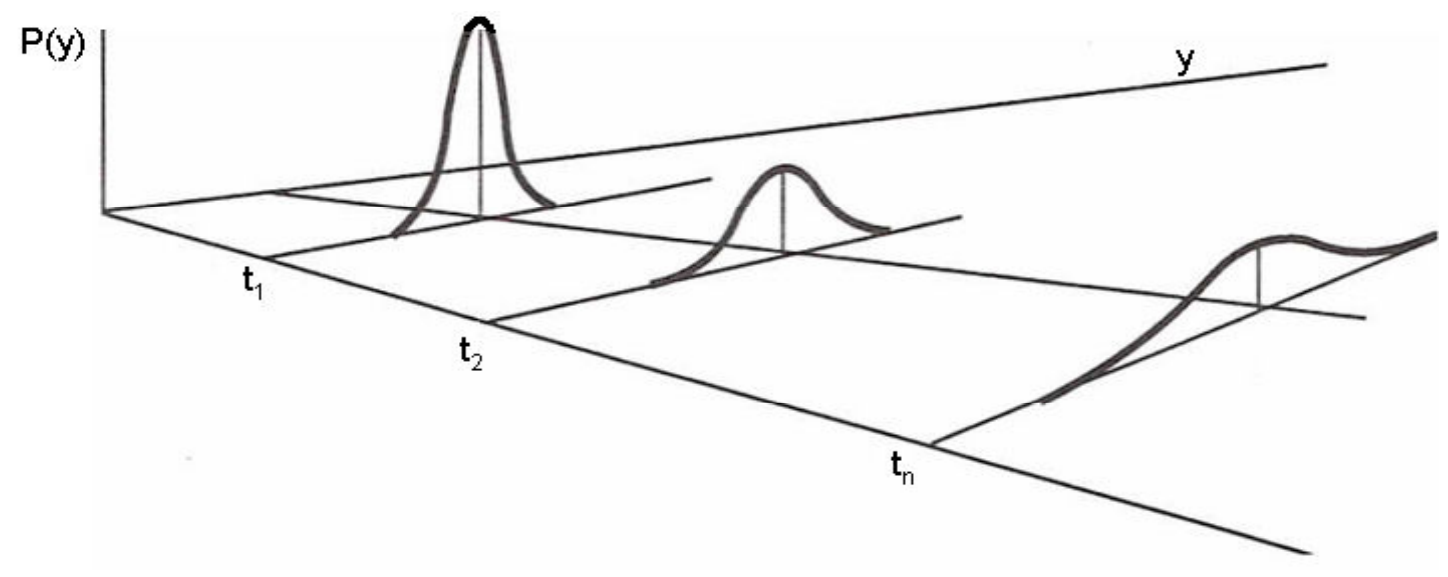

Ilustração 2 - Processo estocástico FONTE: VASCONCELLOS E ALVES, 2000, p. 201 
Vasconcellos e Alves (op. cit., p. 201) explicam:

Em tese, é possível que exista, para cada instante de tempo, uma particular densidade de probabilidade, tal como representada na Ilustração 2. Isso implica dizer que cada variável aleatória $y(t), t=t_{1}, t_{2}, \ldots$, pode ter média e variância específicas.

A Ilustração 2 mostra que o processo estocástico, para cada momento $t$, apresenta inúmeros valores passíveis de serem assumidos pela variável $y_{t}$. No entanto, a série aqui sob estudo é uma série de retornos, portanto uma série econômica (não há inúmeras medições ao longo do dia) para a qual só é possível obter um valor observável (ou uma realização) em cada instante de tempo. Como apontam Vasconcellos e Alves (2000, p. 202):

Para obter mais de uma realização, seria necessário fazer o tempo voltar atrás várias vezes. A impossibilidade de fazer a história repetir-se acarreta problemas para se descobrir o mecanismo gerador da série. No instante $t_{l}$, por exemplo, com apenas um valor observado para o PIB, como determinar a função densidade de probabilidades em $t_{l}$ ou simplesmente a média e a variância da variável aleatória $\mathrm{PIB}$ neste instante de tempo, $\mathrm{E}\left[\mathrm{PIB}\left(t_{1}\right)\right]$ e $\mathrm{V}\left[\mathrm{PIB}\left(t_{1}\right)\right]$, respectivamente?

Vandaele (op. cit., p. 13) e Vasconcellos e Alves (op. cit., p. 202) ensinam que, para estimar a média, variância e autocorrelações de parâmetros de um processo estocástico baseado numa única realização, é necessário que o processo estocástico seja estacionário.

\subsubsection{Estacionariedade}

A estacionariedade de um processo estocástico é obtida quando a média e a variância da série são constantes no tempo, assim como também quando as autocorrelações (ou autocovariâncias) são temporalmente independentes, isto é, elas variam tão-somente em virtude da distância que separam duas observações consideradas (VANSCONCELLOS E ALVES, op. cit., p. 203).

Morettin e Toloi (2006, p. 4-5) explicam as formas de estacionariedade e nãoestacionariedade e como isso está associado aos modelos ARIMA:

Uma série temporal é estacionária quando ela se desenvolve aleatoriamente, no tempo, em torno de uma média constante, refletindo alguma forma de equilíbrio estável. Entretanto, a maior parte das séries que encontramos na prática apresenta alguma forma de não estacionariedade. As séries econômicas apresentam em geral tendências lineares positivas ou negativas. Podemos ter, também, uma forma de não-estacionariedade explosiva, como o crescimento de uma colônia de bactérias.

(...) os modelos ARIMA (autoregressivos-integrados-médias-móveis) serão capazes de descrever de maneira satisfatória séries estacionárias e não-estacionárias, mas que não apresentam 
comportamento explosivo. Este tipo de estacionariedade é chamado homogêneo; a série pode ser estacionária, flutuando ao redor de um nível, por um certo tempo, depois mudar de nível e flutuar ao redor de um novo nível e assim por diante, ou então mudar de inclinação, ou ambas as coisas.

Morettin e Toloi apresentam a figura abaixo para ilustrar o comportamento de uma série nãoestacionária.

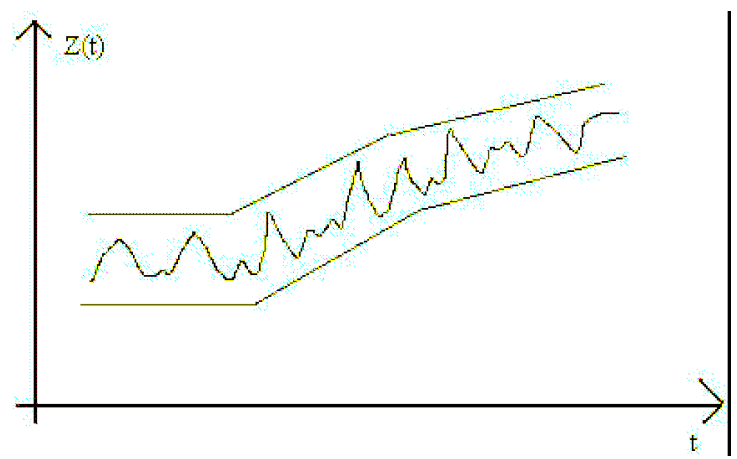

Ilustração 3 - série não-estacionária quanto ao nível e à inclinação FONTE: MORETTIN E TOLOI, 2006, p. 5

Assim, um processo estocástico $\{y(t), t \in T\}$ é estacionário se, para qualquer $t$, forem satisfeitas as três condições:

$$
\begin{aligned}
& E[y(t)]=\mu \\
& V[y(t)]=E[y(t)-\mu]^{2}=\sigma^{2} \\
& E[(y(t)-\mu)(Y(t-k)-\mu)]=f(k), \quad k=1,2, \ldots
\end{aligned}
$$

As duas primeiras condições indicam que a média e a variância de $y(t)$ são invariantes no tempo. A terceira condição impõe que as aucovariâncias variem apenas em função da distância $(k)$ entre observações, sem a influência do tempo (VANSCONCELLOS e ALVES, op. cit., p. 203).

\subsubsection{Modelos de séries de tempo}

Nesta subseção, são apresentados os processos estocásticos estacionários mais freqüentemente utilizados, em especial os modelos auto-regressivo (AR), médias móveis (MA) e uma combinação dos dois (ARMA). 
No modelo auto-regressivo genérico, designado por $\mathrm{AR}(\mathrm{p})$, pressupõe-se que a série $y_{t}$ seja explicada pela soma ponderada de seus p valores passados, assim como por um ruído branco, $\varepsilon_{t}\left(E\left(\varepsilon_{t}\right)=0 ; E\left(\varepsilon_{t}^{2}\right)=\sigma^{2} ; E\left(\varepsilon_{t} \varepsilon_{s}\right)=0\right.$ para $\left.t \neq s\right)$ :

$$
y_{t}=\phi_{1} y_{t-1}+\phi_{2} y_{t-2}+\cdots+\phi_{p} y_{t-p}+\varepsilon_{t}
$$

Equação 5 - equação geral de um modelo auto-regressivo

Por um modelo de médias móveis (MA), a série $y_{t}$ resulta da combinação linear dos choques aleatórios (ruídos brancos) ocorridos no período corrente e nos períodos passados (VANSCONCELLOS e ALVES, op. cit., p. 207). O modelo de médias móveis genérico envolve $q$ valores defasados de $\varepsilon$ e é indicado por $\operatorname{MA}(q)$. Sua equação é:

$$
y_{t}=\varepsilon_{t}-\theta_{1} \varepsilon_{t-1}-\theta_{2} \varepsilon_{t-2}-\cdots-\theta_{q} \varepsilon_{t-q}
$$

\section{Equação 6 - equação geral de um modelo de médias móveis}

O modelo ARMA, como indica o próprio nome, combina o modelo AR com o modelo MA. A especificação genérica de um modelo ARMA admite, pois, um componente auto-regressivo de ordem $p$ e um componente de médias móveis de ordem $q$ e é representado por ARMA (p, q). Sua equação é:

$$
y_{t}=\phi_{1} y_{t-1}+\phi_{2} y_{t-2}+\cdots+\phi_{p} y_{t-p}+\varepsilon_{t}-\theta_{1} \varepsilon_{t-1}-\theta_{2} \varepsilon_{t-2}-\cdots-\theta_{q} \varepsilon_{t-q}
$$

Equação 7 - equação geral de um modelo ARMA

Para simplificação da escrita algébrica das equações ARMA, é comum nos textos sobre séries temporais a introdução do operador de defasagem (backward shift operator), B, definido como $B_{y_{t}}=y_{t-1}$. Então, $B^{2} y_{t}=y_{t-2}$ e, genericamente, $B^{p} y_{t}=y_{t-p}$. A Equação 7, com a inclusão do operador de defasagem, passa a ser reescrita como:

$$
\phi(B) y_{t}=\theta(B) \varepsilon_{t}
$$

Equação 8 - equação geral de um modelo ARMA escrita com operador de defasagem

Assim, a técnica de análise de séries de tempo consegue explicar o comportamento estocástico das séries temporais por meio do seu comportamento passado e de um termo aleatório (também chamado de ruído) que resultam em um modelo ARMA univariado (VANDAELE, op. cit., p. 338). Como mostrado na Ilustração 1, a passagem pelo filtro de integração evidencia que a modelagem ARMA necessita que a série esteja estacionária. Entre as siglas "AR" e "MA", portanto, inclui-se a letra "I" (resultando no termo "ARIMA"), que 
indica o número de integrações (diferenciações) necessárias para tornar $y_{t}$ estacionária Segundo Vandaele (op. cit., p. 21), uma das formas mais empregadas na estacionarização de séries econômicas é a diferenciação, que consiste na subtração de valores de observações entre dois períodos dados. Por exemplo, a diferenciação de primeira ordem é definida como a diferença de valores de duas observações adjacentes; a diferenciação de segunda ordem consiste na diferença da série diferenciada em primeira ordem e assim por diante. Se $y_{t}$ tornarse estacionária após a aplicação de $d$ diferenças, e a série resultante for representada por um modelo ARMA $(p, q)$, diz-se que $y_{t}$ é descrita por um modelo ARIMA $(p, d, q)$ representado por:

$$
w_{t}=\phi_{1} w_{t-1}+\phi_{2} w_{t-2}+\cdots+\phi_{p} y_{t-p}+\varepsilon_{t}-\theta_{1} \varepsilon_{t-1}-\theta_{2} \varepsilon_{t-2}-\cdots-\theta_{q} \varepsilon_{t-q}
$$

Equação 9 - equação geral de um modelo ARIMA

Onde $w_{t}=\nabla^{d} y_{t}$ e $\nabla^{d}$ é o operador de ordem $d \leftrightarrow{ }^{w_{t}}=\nabla^{d} y_{t}$ para $d>0$ e ${ }^{w_{t}}=y_{t}$ para $d=0$. A Equação 8, utilizando-se o operador diferença, pode agora ser reescrita de forma mais genérica como:

$$
\phi(1-B)^{d} y_{t}=\theta(B) \varepsilon_{t}
$$

Equação 10 - equação geral de um modelo ARIMA com o operador diferença

Quando, contudo, séries apresentam quebras estruturais, os modelos ARIMA, sem a inclusão de variáveis de intervenção, podem ter o processo de identificação prejudicado, "levando à escolha de uma especificação incorreta e, conseqüentemente, a estimação e previsão inadequadas" (VASCONCELLOS e ALVES, op. cit., p. 240).

\subsubsection{Análise de intervenção}

A modelagem de eventos excepcionais que modifiquem significativamente a trajetória de uma série muito provavelmente necessitará da inclusão de variáveis que aumentem a aderência do modelo (puramente) ARIMA à realidade dos dados.

A técnica conhecida por análise de intervenção, desenvolvida por Box e Tiao (1975), agrega aos modelos ARIMA variáveis que retratam quebras estruturais decorrentes de eventos exógenos. Matematicamente, um modelo que incorpore apenas uma intervenção (evento) pode ser expresso por (VANCONCELLOS e ALVES, op. cit., p. 240): 


$$
Z_{t}=\frac{\omega(B)}{\delta(B)} I_{t}+n_{t}
$$

Equação 11 - modelo com variável de intervenção

Onde $n_{t}$ é descrito por um ARIMA $(\mathrm{p}, \mathrm{d}, \mathrm{q})$ e $Z_{t}$ é a série temporal com a intervenção. Portanto, o termo $n_{t}$ da Equação 11, que pode ser entendido como uma série ARIMA sem a influência do evento exógeno, pode ser descrito pela Equação 10, como abaixo:

$$
n_{t}=\frac{\theta(B)}{\phi(1-B)^{d}} \varepsilon_{t}
$$

Equação 12 - termo "limpo" dos efeitos da intervenção

Com a substituição de (Equação 12) em (Equação 11), tem-se que:

$$
Z_{t}=\frac{\omega(B)}{\delta(B)} I_{t}+\frac{\theta(B)}{\phi(1-B)^{d}} \varepsilon_{t}
$$

\section{Equação 13 - equação completa de uma série com intervenção}

O primeiro termo à direita do sinal de igualdade em (Equação 13) representa o modelo de intervenção, enquanto o segundo termo é a série modelada sem os efeitos do evento.

A relação entre os polinômios $\omega(B)$ e $\delta(B)$ na Equação 13 traduz a função de correlação entre $Z_{t}$ e a variável de intervenção, $I_{t}$. A razão para o uso de dois polinômios para representar a influência de uma série sobre outra é que essa influência ocorre de forma infinita (e também linear e dinâmica) (VANSCONCELLOS e ALVES, op. cit., p. 233-234). Um polinômio de ordem infinita $(v(B))$ inviabilizaria qualquer aplicação prática do modelo; no entanto, é possível trabalhar com uma estrutura mais parcimoniosa, aproximando aquele polinômio de ordem infinita pela relação de dois polinômios de ordem finita: $\omega(B)$, de ordem $s$, e $\delta(B)$ de ordem $r$ (VANSCONCELLOS e ALVES, op. cit., p. 234). Assim, $v(B)=\frac{\omega(B)}{\delta(B)}=\frac{\left(\omega_{0}+\omega_{1} B+\omega_{2} B^{2}+\cdots+\omega_{s} B^{s}\right)}{\left(1-\delta_{1} B-\delta_{2} B^{2}-\cdots-\delta_{r} B^{r}\right)}$

Segundo Vasconcellos e Alves (op. cit., p. 241), a escolha de $\omega(B)$ e $\delta(B)-$ e, por conseguinte, de $r$ e $s$-é subjetiva e empírica e depende basicamente de duas características da intervenção: 
A determinação da ordem de $\omega(B)$ e $\delta(B)$ não será feita com base em nenhum outro instrumento estatístico; ela será orientada pela avaliação que o pesquisador faz da intervenção fundamentalmente quanto a dois aspectos: o início do impacto da mesma sobre a série $y_{t}$ (imediato e gradual) e a duração do impacto (temporário ou permanente).

A definição da natureza do impacto é realizada mediante o emprego de uma variável dummy, chamada de variável de intervenção, que assume o valor unitário no período do evento e zero nos períodos não afetados por ele.

A depender do tipo de impacto causado pelo evento, a variável de intervenção $\left(I_{t}\right)$ pode ser representada por:

(i) Se o impacto for permanente:

$I_{t}=0$, no período anterior ao evento

$I_{t}=1$, no período posterior ao evento

(ii) Se o impacto for transitório:

$I_{t}=1$, na data do evento

$I_{t}=0$, caso contrário

Nos casos como em (i), a variável de intervenção é chamada de "função degrau" (step function, $S_{t}^{T}$, onde " $T$ " refere-se à data em que o evento se inicia), enquanto em (ii) ela é conhecida como "variável pulso" (pulse variable, $P_{t}^{T}$, onde " $T$ " refere-se à data de ocorrência do evento).

O "formato" do impacto pode ser usualmente classificado como (VANDAELE, op. cit., p. 336):

(a) Intervenção de início abrupto e efeito de duração permanente;

(b) Intervenção de início gradual e efeito de duração permanente;

(c) Intervenção de início abrupto e efeito de duração temporária, ou

(d) Intervenção de início gradual e efeito de duração temporário.

Por fim, o termo $n_{t}$ da Equação 11 é a série temporal livre do efeito das intervenções e é denominada série residual (MORETTIN e TOLOI, op. cit., p. 302). Essa série residual é, portanto, um ruído descrito por um processo $\operatorname{ARIMA}(p, d, q)$, onde $p$ refere-se ao número de 
parâmetros das variáveis auto-regressivas, $d$ é o número de diferenciações e $q$ é o número de parâmetros das variáveis de média móvel.

\subsubsection{Passos para a construção de um modelo ARIMA}

A estratégia para construção de um modelo ARIMA envolve uma abordagem iterativa que pode ser sumarizada conforme ilustra a figura abaixo, adaptada de Box e Jenkins (1976):

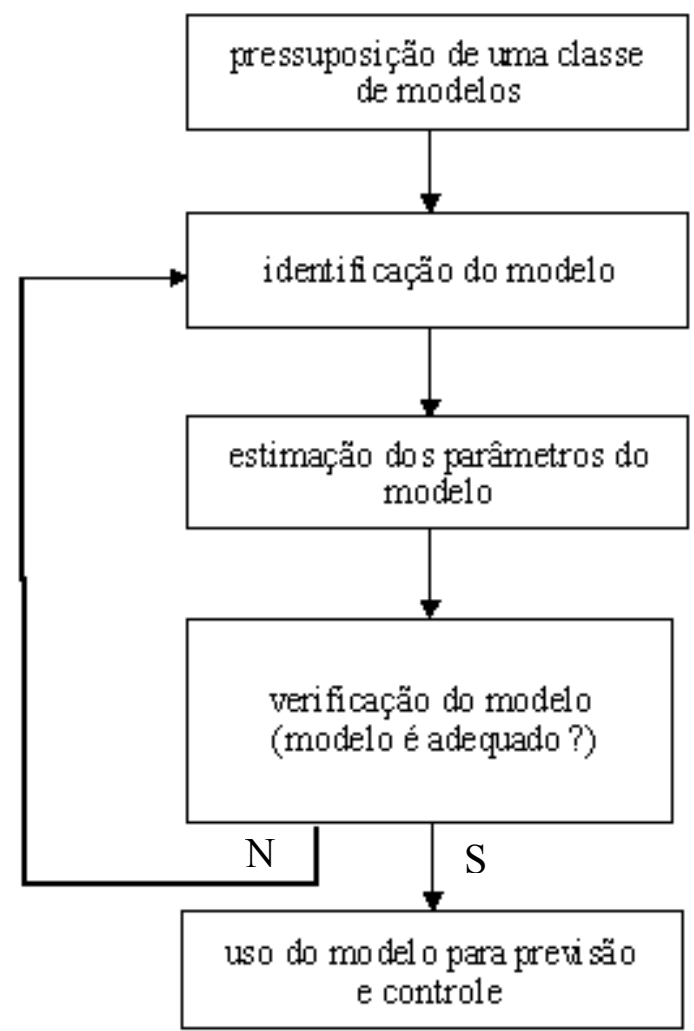

Ilustração 4 - passos para a construção de um modelo ARIMA

No caso do presente estudo, os passos limitam-se a chegar à fase de verificação da adequação do modelo $^{22}$, haja vista que o que se pretende provar é a significância estatística dos parâmetros estimados, em particular do parâmetro associado à variável de intervenção.

\footnotetext{
${ }^{22}$ Os programas estatísticos utilizados nesta parte empírica da tese foram o Eviews, versão 4.0, e o SPSS, versão 16.0 .
} 


\subsection{Especificação dos Modelos}

\subsubsection{NTN-B $\quad$ 2045}

\subsubsection{Identificação do modelo}

O objetivo da identificação é determinar os valores de $p, d$ e $q$ do modelo $\operatorname{ARIMA~}(p, d, q)$. Inicialmente, a série temporal original é diferenciada para se obter uma série estacionária. Com isso, o processo fica reduzido a um modelo $\operatorname{ARMA}(p, q)$. Em seguida, a ordem do processo ARMA é identificada pela análise dos coeficientes de autocorrelação e autocorrelação parcial. Ainda nesta etapa são efetuadas estimativas preliminares dos parâmetros do modelo identificado.

A série de retornos diários da NTN-B de vencimento em 2045 está apresentada abaixo.

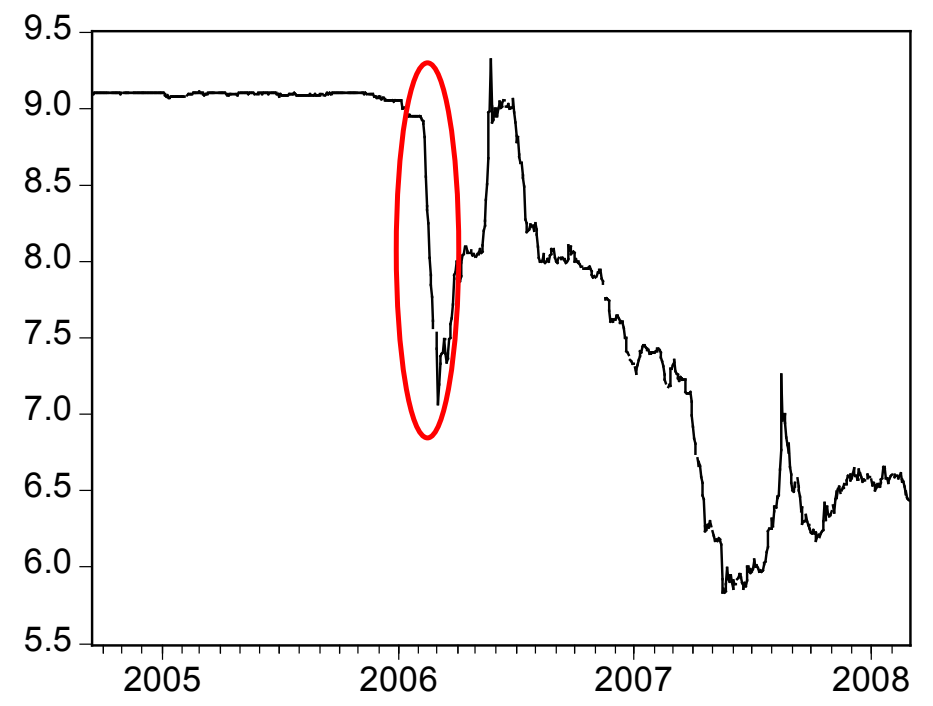

Gráfico 4 - série de retornos diários da NTN-B ${ }_{2045}$ de 16/09/2004 a 28/02/2008

A MP $n^{0}$ 281/2006 entrou em vigor em 16 de fevereiro de 2006, quando foi publicada no "Diário Oficial da União". Visualmente, pode-se observar uma redução acentuada dos retornos diários das $\mathrm{NTN}^{-B_{2045}}$ negociadas no mercado secundário ocorrida proximamente à entrada em vigor da MP (região em destaque no Gráfico 4). 
O Gráfico 4 evidencia que há violação do pressuposto de que a série deve ter, para fins de estacionariedade, variância constante ao longo do tempo. Existem várias transformações matemáticas possíveis de serem aplicadas sobre os dados originais a fim de se obter a constância da variância. $\mathrm{Na}$ prática, porém, as transformações mais utilizadas são a logarítmica e a raiz quadrada (VANDAELE, op. cit., p. 20). Ambas, contudo, mostraram-se incapazes de tornar a série estacionária.

A fim de testar a ordem de integração necessária para tornar uma série estacionária, existe um procedimento chamado teste de raízes unitárias, cuja denominação decorre do fato de que o número de diferenças necessário para tornar uma série estacionária corresponde ao número de raízes sobre o círculo unitário, ou raízes unitárias, presentes no processo gerador dessa série (VANCONCELlOS; ALVES, op. cit., p. 246). Em suma, a presença de uma raiz unitária indica que a série não é estacionária.

Segundo Vasconcellos e Alves (op. cit., p. 246):

Os testes mais difundidos se destinam a séries que têm, no máximo, uma raiz unitária, ou seja, séries que são originalmente estacionárias ou são estacionarizadas com a aplicação de uma diferença. De acordo com inúmeros trabalhos empíricos, entre os quais destaca-se o de Nelson e Plosser (1982), grande parte das séries macroeconômicas são integradas de ordem 1.

Diferenciando-se a série de retornos originais, os testes de raízes unitárias ADF, Augmented Dickey-Fuller, e PP, Phillips-Perron ${ }^{23}$, dão conta de que a série ficou estacionária, como se vê nos números abaixo.

Tabela 6 - testes ADF e PP de raiz unitária para a série diferenciada dos retornos da NTN-B 2045.

\begin{tabular}{lccc}
\hline & & \multicolumn{2}{c}{ Valores Críticos* } \\
\hline \multicolumn{1}{c}{ ADF } & Estatística t & $1 \%$ & $5 \%$ \\
Com intercepto & $-8,4753$ & $-3,4427$ & $-2,8662$ \\
Com intercepto e tendência & $-8,4783$ & $-3,9764$ & $-3,4187$ \\
Sem intercepto nem tendência & $-8,4067$ & $-2,5688$ & $-1,9399$ \\
\multicolumn{1}{c}{ Perron } & & & \\
Com intercepto & & & \\
Com intercepto e tendência & $-25,0988$ & $-3,4412$ & $-2,8656$ \\
Sem intercepto nem tendência & $-25,0890$ & $-3,9744$ & $-3,4177$ \\
\hline
\end{tabular}

* Valores críticos para rejeição da hipótese de raiz unitária de acordo com Mackinnon.

\footnotetext{
${ }^{23}$ Ambos os testes, ADF e PP, testam a hipótese nula de que há raiz unitária, ou seja, a rejeição da hipótese é uma evidência de que a série é estacionária.
} 
Os testes, a despeito de rejeitarem a hipótese de existência de raiz unitária, não são confirmados pela observação do gráfico da série diferenciada:

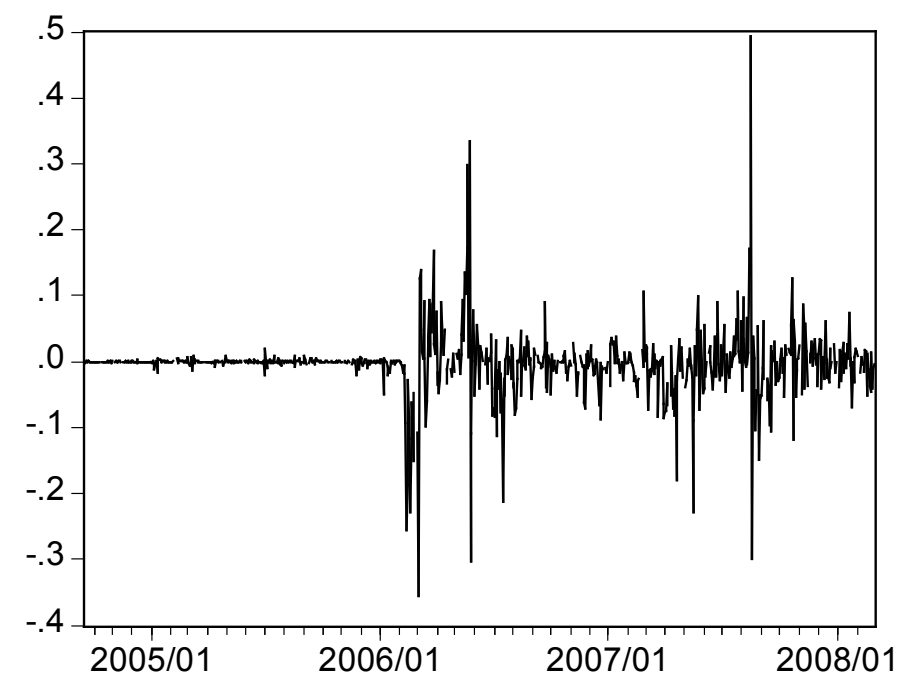

Gráfico 5 - série da $1^{\text {a }}$ diferença dos retornos da NTN-B ${ }_{2045}$.

O Gráfico 5 mostra claramente que a variância não é constante ao longo do tempo. A partir de fevereiro de 2006, a volatilidade dos retornos aumentou consideravelmente em comparação ao período anterior. Mas por que então os testes de raiz unitária apontam a série como estacionária, ainda que uma simples inspeção visual do Gráfico 5 indique o contrário? A resposta é que os testes de raiz unitária (assim como os demais testes) deixam de "funcionar" corretamente quando a série apresenta uma quebra estrutural, como parece ser o caso.

A tarefa principal da fase de identificação é determinar o modelo $\operatorname{ARIMA~}(p, d, q)$ que mais bem se ajusta aos retornos. Mais precisamente, identificar o modelo da Equação 11 ou da Equação 13. Infelizmente, como diz Vandaele (op. cit., p. 339), em virtude da parte referente à intervenção, os recursos utilizados normalmente para identificação de modelos não necessariamente revelam o processo ARIMA subjacente.

Uma das formas sugeridas por Vandaele (op. cit., p. 339) para identificar modelos que contenham uma parte representativa da intervenção é utilizar as observações anteriores à intervenção. Se o número de observações for suficientemente grande, identifica-se o modelo ARIMA da parte "descontaminada" e depois, separadamente, o da parte da intervenção. O segundo termo da Equação 11 representa a série livre dos efeitos da intervenção. 
Considerando-se o que demonstra o Gráfico 5, serão utilizados, para fins de identificação dessa série "limpa", os retornos diários do período de 3/1/2005 a 9/2/2006, um total de 280 observações. Como se verá adiante, o dia 9/2/2006 é considerado o último dia da série limpa, pois os efeitos da MP $n^{\circ}$ 281/2006 começaram a ser mais sentidos pelos retornos a partir do dia 10/2/2006.

O gráfico abaixo demonstra que a série de retornos original claramente é não-estacionária.

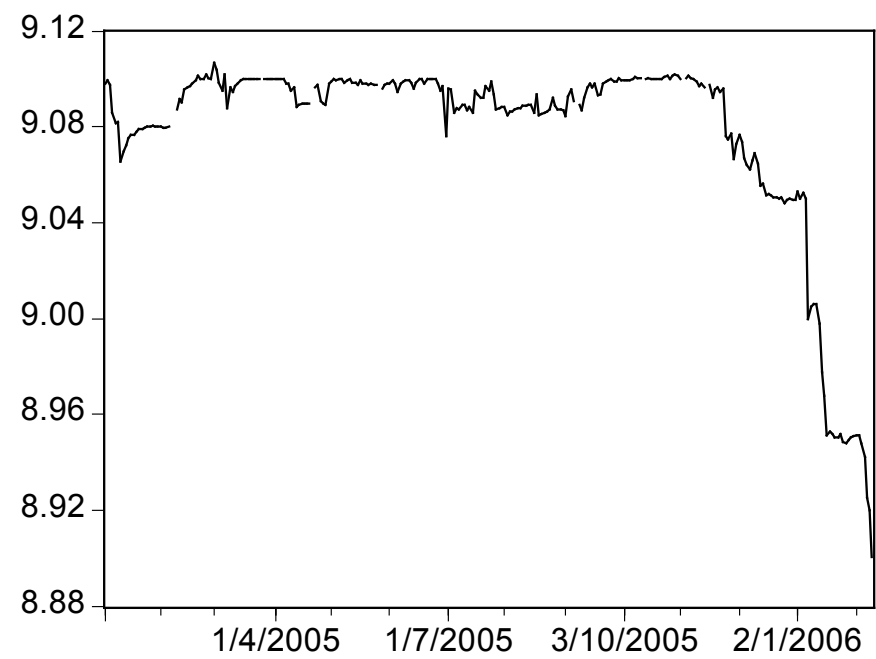

Gráfico 6 - série diária de retornos original da NTN-B ${ }_{2045}$ de 3/1/05 a 9/2/06

As primeiras diferenças, contudo, parecem torná-la estacionária, como aparentemente demonstra o gráfico a seguir:

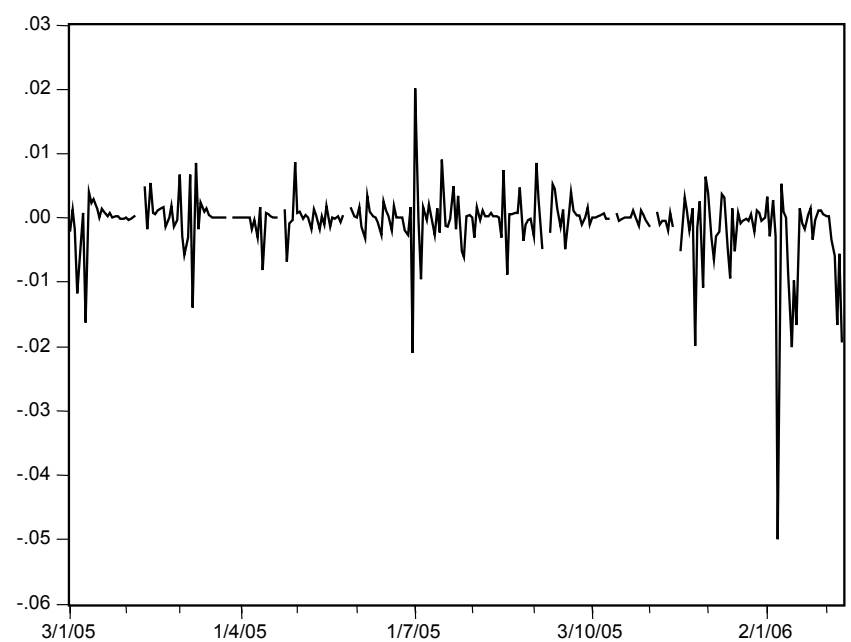

Gráfico 7 - primeiras diferenças dos retornos diários NTN-B2045 de 3/1/2005 a 9/2/2006 
Os testes de raiz unitária da série das primeiras diferenças dos retornos diários desse subconjunto de observações indicam que a diferenciação de $1^{a}$ ordem foi suficiente para a estacionarização do processo:

Tabela 7 - testes ADF e PP de raiz unitária relativos à série de primeiras diferenças dos retornos NTN$B_{2045}(3 / 1 / 2005$ a 9/2/2006).

\begin{tabular}{lcc}
\hline \multicolumn{3}{c}{ ADF Test Statistic } \\
\hline-5.177503 & Com intercepto & -3.4600 \\
& $5 \%$ Critical Value* & -2.8741 \\
& $10 \%$ Critical Value & -2.5734 \\
& Com intercepto e tendência \\
-5.775611 & $1 \%$ Critical Value* \\
& $5 \%$ Critical Value & -4.0007 \\
& $10 \%$ Critical Value & -3.4303 \\
-4.694467 & Sem intercepto nem tendência & -3.1385 \\
& $1 \%$ Critical Value* & -2.5744 \\
& $5 \%$ Critical Value & -1.9410 \\
& $10 \%$ Critical Value & -1.6164 \\
\hline
\end{tabular}

*MacKinnon critical values for rejection of hypothesis of a unit root.

\begin{tabular}{lcc}
\hline \multicolumn{3}{c}{ PP Test Statistic } \\
\hline-16.86057 & Com intercepto & \\
& $5 \%$ Critical Value* & -3.4567 \\
& $10 \%$ Critical Value & -2.8726 \\
& Com intercepto e tendência & -2.5726 \\
-17.33311 & $1 \%$ Critical Value* & -3.9961 \\
& $5 \%$ Critical Value & -3.4282 \\
& $10 \%$ Critical Value & -3.1372 \\
-16.55866 & Sem intercepto nem tendência & \\
& $1 \%$ Critical Value* & -2.5734 \\
& $5 \%$ Critical Value & -1.9408 \\
& $10 \%$ Critical Value & -1.6163 \\
\hline
\end{tabular}

* MacKinnon critical values for rejection of hypothesis of a unit root.

Os testes ADF e PP, contudo, detectam apenas a existência de uma raiz unitária. Vasconcellos e Alves (op.cit., p. 248) recomendam o uso do teste de Dickey e Pantula para verifcar a presença de mais de uma raiz unitária. Trata-se, na verdade, de uma seqüência de testes, realizados como a seguir: começa-se pelo maior número presumido de raízes unitárias, e reduz-se esse número de um em um cada vez que a hipótese nula, $\mathrm{H}_{0}{ }^{\mathrm{d}}$, de que existem $d$ raízes unitárias, for rejeitada. $\mathrm{O}$ procedimento termina quando a última $\mathrm{H}_{0}$ for rejeitada ou aceita.

Aplicando-se o teste de Dickey e Pantula com auxílio do Eviews, obetiveram-se os seguintes resultados para a exitência de, no máximo, três raízes unitárias: 
Tabela 8 - Teste de Dickey e Pantula para $\mathrm{H}_{0}{ }^{3}: \mathbf{d}=3$ (três raízes unitárias) e $\mathrm{H}_{1}{ }^{3}: \mathbf{d}=2$

Dependent Variable: D(V2045,3)

Method: Least Squares

Sample: 3/01/2005 9/02/2006

Included observations: 289

\begin{tabular}{lrllr}
\hline \hline \multicolumn{1}{c}{ Variable } & Coefficient & Std. Error & t-Statistic & Prob. \\
\hline \hline C & $-7.75 E-05$ & 0.000368 & -0.210675 & 0.8333 \\
$\mathrm{D}(\mathrm{V} 2045(-1), 2)$ & -1.549492 & 0.049727 & -31.15993 & 0.0000 \\
\hline \hline R-squared & 0.771849 & Mean dependent var & $-4.64 \mathrm{E}-05$ \\
Adjusted R-squared & 0.771054 & S.D. dependent var & 0.013064 \\
S.E. of regression & 0.006251 & Akaike info criterion & -7.305333 \\
Sum squared resid & 0.011214 & Schwarz criterion & -7.279959 \\
Log likelihood & 1057.621 & F-statistic & 970.9411 \\
Durbin-Watson stat & 2.431518 & Prob(F-statistic) & 0.000000 \\
\hline \hline
\end{tabular}

Tabela 9 - Teste de Dickey e Pantula para $\mathrm{H}_{0}{ }^{2}: \mathrm{d}=2$ (duas raízes unitárias) e $\mathrm{H}_{1}^{2}: \mathrm{d}=1$

\begin{tabular}{lrlrr}
\multicolumn{1}{c}{ Variable } & Coefficient & Std. Error & t-Statistic & Prob. \\
\hline \hline C & -0.000689 & 0.000311 & -2.215388 & 0.0275 \\
$\mathrm{D}(\mathrm{V} 2045(-1), 2)$ & -1.050553 & 0.060550 & -17.35023 & 0.0000 \\
$\mathrm{D}(\mathrm{V} 2045(-1), 1)$ & -0.996352 & 0.088194 & -11.29726 & 0.0000 \\
\hline \hline R-squared & 0.842247 & Mean dependent var & $-4.64 \mathrm{E}-05$ \\
Adjusted R-squared & 0.841144 & S.D. dependent var & 0.013064 \\
S.E. of regression & 0.005207 & Akaike info criterion & -7.667388 \\
Sum squared resid & 0.007754 & Schwarz criterion & -7.629328 \\
Log likelihood & 1110.937 & F-statistic & 763.4804 \\
Durbin-Watson stat & 1.968005 & Prob(F-statistic) & 0.000000 \\
\hline \hline
\end{tabular}

Tabela 10 - Teste de Dickey e Pantula para $\mathrm{H}_{0}{ }^{1}: \mathrm{d}=1$ (uma raíz unitária) e $\mathrm{H}_{1}{ }^{1}: \mathrm{d}=0$

\begin{tabular}{crlrr}
\multicolumn{1}{c}{ Variable } & Coefficient & Std. Error & t-Statistic & Prob. \\
\hline \hline C & -0.297450 & 0.076882 & -3.868922 & 0.0001 \\
D(V2045(-1),2) & -0.979610 & 0.061921 & -15.82044 & 0.0000 \\
D(V2045(-1),1) & -1.143163 & 0.094150 & -12.14188 & 0.0000 \\
V2045(-1) & 0.032676 & 0.008465 & 3.859990 & 0.0001 \\
\hline \hline R-squared & 0.850084 & Mean dependent var & $-4.64 \mathrm{E}-05$ \\
Adjusted R-squared & 0.848506 & S.D. dependent var & 0.013064 \\
S.E. of regression & 0.005085 & Akaike info criterion & -7.711425 \\
Sum squared resid & 0.007368 & Schwarz criterion & -7.660679 \\
Log likelihood & 1118.301 & F-statistic & 538.6900 \\
Durbin-Watson stat & 1.970171 & Prob(F-statistic) & 0.000000 \\
\hline \hline
\end{tabular}

Rejeitam-se as hipóteses nulas se os coeficientes das estatísticas asscoiadas aos parâmetros das equações forem significativamente diferentes de zero. Todos as hipóteses foram rejeitadas, ou seja, aceita-se a hipótese de inexistência de até três raízes unitárias.

O passo seguinte na etapa de identificação é procurar modelar o processo gerador da série de retornos antes do período da intervenção. Um recurso particularmente útil nessa tarefa são as FAC, funções de autocorrelação, e as FACP, funções de autocorrelação parcial. Comparando- 
se as FAC e as FACP de uma amostra com as funções de autocorrelações teóricas (da população), pode-se identificar qual tipo de modelo possui melhor ajuste aos dados. Vandaele (op. cit., p.112) defende o uso das funções de autocorrelação na identificação de modelos: “Apesar de esse processo requerer uma grande dose de julgamento, que pode ser alcançado com a experiência, essas ferramentas [FAC e FACP] têm provado ser muito valiosas no estreitamento das opções de modelos ARIMA que podem ser considerados para representar uma particular série temporal. ${ }^{24, " ~(t r a d u c ̧ a ̃ o ~ l i v r e) ~}$

Quando se comentou sobre estacioanariedade (item 4.2.2), uma das três condições necessárias para considerar uma série estacionária é que a autocorrelação entre quaisquer duas observações no tempo, $t$ e $s$, dependa apenas da distância entre elas e não do período de tempo a que se refiram. Matematicamente, a autocorrelação pode então ser definida como:

$$
\rho_{t-s}=\frac{E\left[\left(z_{t}-\mu\right)\left(z_{s}-\mu\right)\right]}{\sigma^{2}}
$$

\section{Equação 14 - expressão da autorrelação}

Um dos recursos mais utilizados na interpretação de um conjunto de autocorrelações é um gráfico que aponta as autocorrelações nos respectivos lags (distâncias). Esse gráfico é chamado de função de autocorrelação, $\mathrm{FAC}^{25}$, ou correlograma.

Uma autocorrelação alta entre duas observações indica uma relação de causa e efeito entre elas, o que pode violar a condição de estacionariedade de uma série. No entanto, como informa Vandaele (op. cit., p. 66), uma série em que os valores de autocorrelação são altos nos primeiros lags não necessariamente revela a sua condição de não-estacionariedade. O que sugere a necessidade de outras diferenciações é que a FAC decresça lentamente e, portanto, as autocorrelações permaneçam diferentes de zero mesmo para lags altos. A persistência de alta autocorrelação entre observações distantes no tempo deve ser interpretada como uma possível indicação de que a série não é estacionária.

Como complemento à análise das FAC, é possível testar conjuntamente se os $k$ primeiros coeficientes de autocorrelação são estatisticamente iguais a zero (VASCONCELLOS;

\footnotetext{
${ }^{24}$ Although this process does require a great deal of judgment which can be acquired with experience, these tools have proven to be quite valuable in narrowing down the class of ARIMA models that should be considered to represent a particular time series.

${ }^{25}$ Nos pacotes estatísticos, a função de autocorrelação é representada normalmente pela sua sigla em inglês, ACF. No caso do Eviews, a sigla é AC.
} 
ALVES, op. cit., p. 214). Segundo Vandaele (op. cit., p. 108), citando Box e Pierce (1970), esses dois autores mostraram que, para um processo puramente randômico, ou seja, um modelo com todos os $\rho_{k}=0$, a estatística $Q$-teste de Ljung-Box é dada por:

$$
Q(k)=n(n+2) \sum_{k=1}^{k} \frac{1}{n-k} r_{k}^{2} \rightarrow \chi^{2}(k)
$$

Equação 15 - Q-teste de Ljung-Box

A hipótese nula testada pela estatística de Ljung-Box é a de que não existe autocorrelação até a observação (lag) de ordem $k$.

Por seu turno, a FACP tem uma interpretação um pouco mais complexa. Para Vasconcellos e Alves (op. cit., p. 214), "O coeficiente de correlação parcial de ordem k (...) mede a correlação entre $\mathrm{y}_{\mathrm{t}}$ e $\mathrm{y}_{\mathrm{t}-\mathrm{k}}$ depois que a influência entre $\mathrm{y}_{\mathrm{t}-1}, \mathrm{y}_{\mathrm{t}-2}, \ldots, \mathrm{y}_{\mathrm{t}-\mathrm{k}+1}$ sobre $\mathrm{y}_{\mathrm{t}}$ foi descontada". Assim, numa definição mais intuitiva, a autocorrelação parcial é a correlação entre observações vizinhas em uma série temporal removendo a correlação dos outros vizinhos. Vandaele (op. cit., p. 85) observa que, dada a dificuldade em distinguir, às vezes, entre dois possíveis modelos com base apenas na FAC, a FACP se constitui em um apoio interessante na tarefa de distingui-los.

A figura abaixo contém o correlograma da série original de retornos da NTN-B 2045 para o período pré-intervenção. 
Sample: 3/01/2005 9/02/2006

Included observations: 280

\begin{tabular}{|c|c|c|c|c|c|c|}
\hline Autocorrelation & Partial Correlation & & $\mathrm{AC}$ & PAC & Q-Stat & Prob \\
\hline$.\left.\right|^{* * * * * * *} \mid$ & $.||^{* \star * * * * *} \mid$ & 1 & 0.951 & 0.951 & 256.00 & 0.000 \\
\hline$.\left.\right|^{\star * \star \star \star \star \star \star} \mid$ & $.1^{*}$ & 2 & 0.915 & 0.115 & 494.05 & 0.000 \\
\hline$.\left.\right|^{\star * \star * \star \star \star *} \mid$ & . & 3 & 0.881 & 0.014 & 715.40 & 0.000 \\
\hline$.\left.\right|^{\star * \star * \star \star \star *} \mid$ &. & 4 & 0.852 & 0.044 & 923.15 & 0.000 \\
\hline$.\left.\right|^{\star * \star \star \star *} \mid$ & . & 5 & 0.826 & 0.028 & 1118.9 & 0.000 \\
\hline$.\left.\right|^{* * * * * *} \mid$ & .1. & 6 & 0.799 & -0.010 & 1302.7 & 0.000 \\
\hline$.\left.\right|^{* \star \star * \star *} \mid$ & . & 7 & 0.771 & -0.017 & 1474.5 & 0.000 \\
\hline.$\left.\right|^{* * * * * *}$ & . & 8 & 0.741 & -0.037 & 1633.7 & 0.000 \\
\hline.$\left.\right|^{* * * * *}$ & . & 9 & 0.711 & -0.022 & 1780.8 & 0.000 \\
\hline.$f^{* * * * *}$ & . & 10 & 0.679 & -0.036 & 1915.7 & 0.000 \\
\hline.$\left.\right|^{* \star \star \star *}$ &. & 11 & 0.647 & -0.037 & 2038.5 & 0.000 \\
\hline.$\left.\right|^{* \star \star \star *}$ &. & 12 & 0.615 & -0.018 & 2150.0 & 0.000 \\
\hline $.1^{* * \star *}$ &. & 13 & 0.586 & 0.007 & 2251.7 & 0.000 \\
\hline$f^{* * * *}$ &. & 14 & 0.554 & -0.047 & 2342.8 & 0.000 \\
\hline$f^{* * * *}$ &. & 15 & 0.523 & -0.017 & 2424.2 & 0.000 \\
\hline$f^{* \star * *}$ &. & 16 & 0.491 & -0.029 & 2496.2 & 0.000 \\
\hline$f^{* * *}$ & . & 17 & 0.457 & -0.042 & 2558.8 & 0.000 \\
\hline.$\left.\right|^{* * *}$ &. & 18 & 0.421 & -0.052 & 2612.2 & 0.000 \\
\hline.$\left.\right|^{* * *}$ &. $\mid$. & 19 & 0.391 & 0.037 & 2658.6 & 0.000 \\
\hline..$^{* * *}$ & . & 20 & 0.362 & -0.009 & 2698.4 & 0.000 \\
\hline..$^{\star * *}$ &. & 21 & 0.340 & 0.063 & 2733.7 & 0.000 \\
\hline.$\left.\right|^{* *}$ & . & 22 & 0.323 & 0.058 & 2765.5 & 0.000 \\
\hline..$^{* *}$ &. & 23 & 0.302 & -0.017 & 2793.6 & 0.000 \\
\hline.$\left.\right|^{* *}$ & . & 24 & 0.280 & -0.023 & 2817.9 & 0.000 \\
\hline.$\left.\right|^{* *}$ & . & 25 & 0.254 & -0.053 & 2837.9 & 0.000 \\
\hline.$\left.\right|^{* *}$ & . ${ }^{*}$ & 26 & 0.244 & 0.136 & 2856.5 & 0.000 \\
\hline.$\left.\right|^{* *}$ & . & 27 & 0.237 & 0.061 & 2874.0 & 0.000 \\
\hline.$\left.\right|^{* *}$ & . & 28 & 0.230 & 0.013 & 2890.6 & 0.000 \\
\hline $.1^{* *}$ & . & 29 & 0.224 & 0.006 & 2906.3 & 0.000 \\
\hline $.1^{* *}$ &. $\mid$. & 30 & 0.215 & -0.016 & 2920.9 & 0.000 \\
\hline.$\left.\right|^{* *}$ &. & 31 & 0.206 & -0.006 & 2934.4 & 0.000 \\
\hline $.1^{*}$ & . & 32 & 0.195 & -0.046 & 2946.4 & 0.000 \\
\hline . $\left.\right|^{*}$ &. $\mid$. & 33 & 0.183 & -0.026 & 2957.1 & 0.000 \\
\hline . $\left.\right|^{*}$ & . & 34 & 0.171 & -0.034 & 2966.5 & 0.000 \\
\hline ..$^{*}$ & . & 35 & 0.160 & -0.016 & 2974.7 & 0.000 \\
\hline.$\left.\right|^{*}$ & .1. & 36 & 0.147 & -0.051 & 2981.7 & 0.000 \\
\hline
\end{tabular}

Ilustração 5 - correlograma da série original de retornos da NTN-B ${ }_{2045}$ de 3/1/2005 a 9/2/2006

O correlograma da série original já fornece algumas informações interessantes. Note-se que as estatísticas $Q$ de Ljung-Box e seus p-values (duas últimas colunas da Ilustração 5) indicam que não se pode rejeitar a hipótese de inexistência de correlação até o último lag. Como sugere o correlograma, a série original é um random walk ou passeio aleatório. Observe-se que as autocorrelações declinam muito lentamente, uma evidência de que a série não é estacionária. Vandaele (op. cit., p. 68) apresenta um correlograma típico de um passeio aleatório que guarda grande semelhança com o correlograma da Ilustração 5. 
O correlograma das primeiras diferenças da série de retornos da $\mathrm{NTN}-\mathrm{B}_{2045}$ para o período pré-intervenção vem a seguir:

Sample: 3/01/2005 9/02/2006 Included observations: 272

\begin{tabular}{|c|c|c|c|c|c|c|}
\hline Autocorrelation & Partial Correlation & & $A C$ & PAC & Q-Stat & Prob \\
\hline .1 & .1. & & -0.057 & -0.057 & 0.8916 & 0.345 \\
\hline. &. & 2 & 0.055 & 0.052 & 1.7352 & 0.420 \\
\hline . ${ }^{*}$ & $.1^{*}$ & 3 & 0.085 & 0.092 & 3.7416 & 0.291 \\
\hline. & . & 4 & -0.028 & -0.021 & 3.9597 & 0.411 \\
\hline . &.$\left.\right|^{*}$ & 5 & 0.092 & 0.081 & 6.3443 & 0.274 \\
\hline.$^{*}$ & $.1^{*}$ & 6 & 0.105 & 0.112 & 9.4507 & 0.150 \\
\hline . & . . $^{*}$ & 7 & 0.089 & 0.100 & 11.673 & 0.112 \\
\hline . &. & & -0.018 & -0.034 & 11.766 & 0.162 \\
\hline . & . & 9 & -0.012 & -0.040 & 11.807 & 0.224 \\
\hline . &. & 10 & 0.031 & 0.014 & 12.073 & 0.280 \\
\hline${ }^{*} \mid$. & $\star$ & 11 & -0.085 & -0.094 & 14.150 & 0.225 \\
\hline. &. & 12 & -0.007 & -0.051 & 14.163 & 0.290 \\
\hline. &. & 13 & 0.061 & 0.047 & 15.219 & 0.294 \\
\hline. &. & 14 & -0.002 & 0.027 & 15.220 & 0.363 \\
\hline. & . & 15 & 0.034 & 0.038 & 15.550 & 0.413 \\
\hline . &.$\left.\right|^{*}$ & 16 & 0.084 & 0.099 & 17.588 & 0.349 \\
\hline .1 . &.$t^{*}$ & 17 & 0.049 & 0.089 & 18.292 & 0.371 \\
\hline . & . ${ }^{*}$ & 18 & 0.112 & 0.132 & 21.965 & 0.234 \\
\hline ..$^{*}$ & 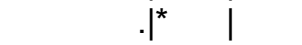 & 19 & 0.092 & 0.090 & 24.481 & 0.178 \\
\hline. &. & 20 & -0.003 & -0.030 & 24.485 & 0.222 \\
\hline . & . & 21 & 0.017 & -0.036 & 24.572 & 0.266 \\
\hline ..$^{*}$ & . $\left.\right|^{*}$ & 22 & 0.133 & 0.084 & 29.818 & 0.123 \\
\hline ..$^{*}$ & . & 23 & 0.090 & 0.059 & 32.257 & 0.095 \\
\hline $.1^{*}$ & $.1^{*}$ & 24 & 0.138 & 0.107 & 37.952 & 0.035 \\
\hline. $\mid$. & . & 25 & 0.040 & 0.017 & 38.431 & 0.042 \\
\hline. $\mid$. & *l. & 26 & -0.053 & -0.067 & 39.271 & 0.046 \\
\hline${ }^{*} \mid$. & $\star$ & 27 & -0.061 & -0.088 & 40.418 & 0.047 \\
\hline.$\left.\right|^{*}$ & .1. & 28 & 0.076 & 0.052 & 42.185 & 0.042 \\
\hline .1. & .1. & 29 & -0.011 & -0.029 & 42.219 & 0.054 \\
\hline. $\mid$. & . & 30 & 0.023 & -0.004 & 42.377 & 0.066 \\
\hline.$^{*}$ &.$\left.\right|^{*}$ & 31 & 0.118 & 0.103 & 46.702 & 0.035 \\
\hline . & . & 32 & -0.047 & -0.009 & 47.392 & 0.039 \\
\hline. $\mid$. & . $\left.\right|^{*}$ & 33 & 0.063 & 0.087 & 48.615 & 0.039 \\
\hline *. & $*$ & 34 & -0.094 & -0.105 & 51.399 & 0.028 \\
\hline. &. & 35 & 0.051 & 0.017 & 52.219 & 0.031 \\
\hline & .1. & 36 & 0.056 & 0.031 & 53.202 & 0.032 \\
\hline
\end{tabular}

Ilustração 6 - correlograma das primeiras diferenças dos retornos diários da NTN-B ${ }_{2045} 3 / 1 / 2005$ a 9/2/2006

O correlograma das primeiras diferenças da série de retornos indica que a série diferenciada é estacionária. Os p-values da estatística $Q$, nos vários lags, indicam que não se pode rejeitar a hipótese de ausência de autocorrelação até o último lag. Como ensina Vandaele (op. cit., pp. 67 e 68), as primeiras diferenças de um passeio aleatório transformam-no em um ruído branco. 
Em um modelo puramente ruído branco, $y_{t}=\varepsilon_{t}$, a série é explicada apenas por um termo estocástico contemporâneo. A série, portanto, não é explicada nem por seus valores anteriores nem por choques passados. Dessa forma, os retornos da NTN-B ${ }_{2045}$, no período "normal" (sem os efeitos da intervenção), são descritos por um $\operatorname{ARIMA}(0,1,0)$.

Passa-se, agora, para a identificação da parte referente à intervenção. A análise de intervenção requer, como mencionado, a especificação de uma data de início do evento, sua duração e de que forma se deu o seu impacto. O Gráfico 8, abaixo, ilustra o comportamento dos retornos diários da NTN-B 2045 nos três primeiros meses de 2006 e deixa evidente que o declínio mais acentuado deu-se a partir de 10/02/2006.

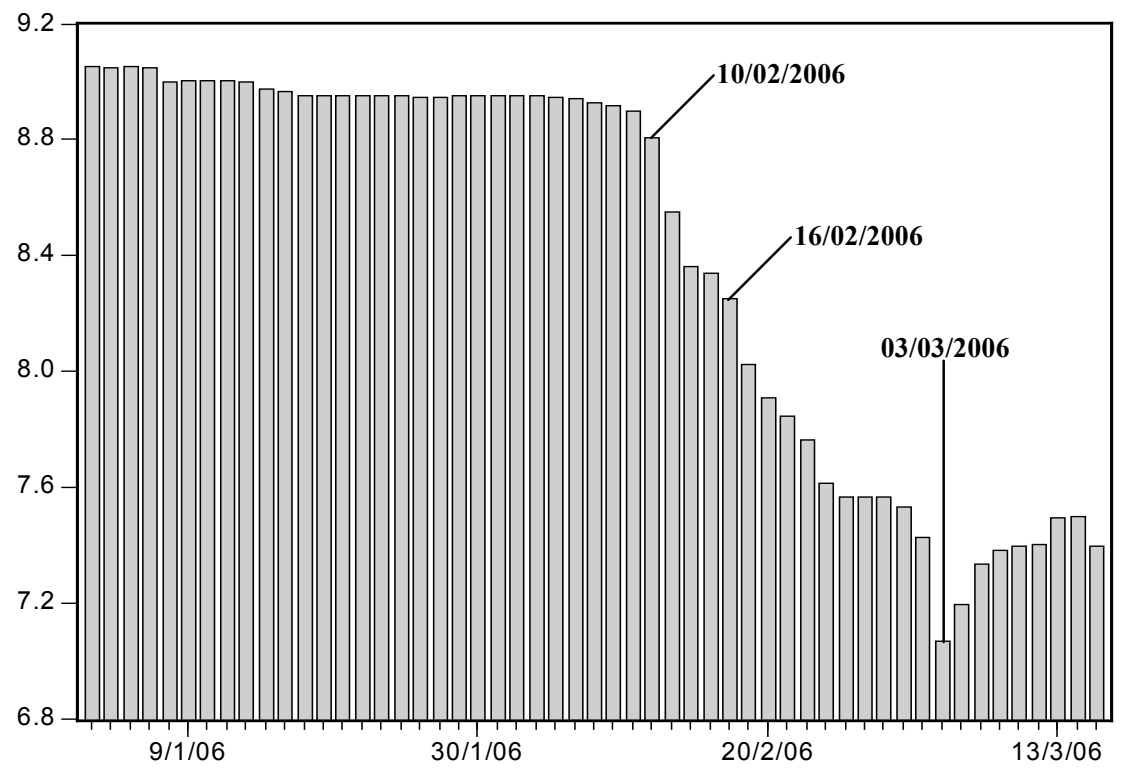

Gráfico 8 - retornos da NTN-B 2045 , de janeiro de 2006 a meados de fevereiro de 2006

Cabe observar que apenas os rendimentos produzidos por títulos públicos adquiridos por estrangeiros, a partir de 16 de fevereiro de 2006, quando pagos, creditados, entregues ou remetidos a beneficiário residente ou domiciliado no exterior, poderiam se beneficiar da isenção introduzida pela MP $n^{\circ}$ 281/2006. Não haveria, portanto, sentido em considerar o início do evento antes de 16/2/2006, já que o investidor estrangeiro só faria jus à isenção se adquirisse o título a partir daquela data. No entanto, os parágrafos $2^{\circ}$ e $3^{\circ}$ do art. $1^{\circ}$ da MP estendiam ao investidor estrangeiro a isenção sobre os rendimentos dos títulos possuídos em 15 de fevereiro de 2006: 
Art. $1^{\circ}$ Fica reduzida a zero a alíquota do imposto de renda incidente sobre os rendimentos, definidos nos termos da alínea "a" do $§ 20$ do art. 81 da Lei no 8.981, de 20 de janeiro de 1995, produzidos por títulos públicos federais, adquiridos a partir da data de publicação desta Medida Provisória, quando pagos, creditados, entregues ou remetidos a beneficiário residente ou domiciliado no exterior, exceto em país que não tribute a renda ou que a tribute à alíquota máxima inferior a vinte por cento.

(...)

$\S 2^{\underline{0}}$ Os rendimentos produzidos pelos títulos e valores mobiliários, referidos no caput e no $\S 1^{\underline{0}}$, adquiridos anteriormente à data de publicação desta Medida Provisória continuam tributados na forma da legislação vigente, facultada a opção pelo pagamento antecipado do imposto nos termos do $\S 3^{\circ}$.

$\S 3^{\text {o }}$ Até 31 de agosto de 2006, relativamente aos investimentos possuídos no dia útil anterior à data de publicação desta Medida Provisória, fica facultado ao investidor estrangeiro antecipar o pagamento do imposto de renda incidente sobre os rendimentos produzidos por títulos públicos federais, que seria devido por ocasião do pagamento, crédito, entrega ou remessa a beneficiário residente ou domiciliado no exterior, ficando os rendimentos auferidos a partir da data do pagamento do imposto sujeitos ao benefício da alíquota zero previsto neste artigo.

Assim, o investidor estrangeiro que adquirisse o título mesmo antes da data de publicação da MP $n^{\circ}$ 281/2006, 16 de fevereiro de 2006, poderia se aproveitar da isenção, desde que obedecidos os parágrafos supramencionados da medida provisória. É bem possível que o investidor estrangeiro tenha avaliado que a aquisição dos títulos antes do ato legal, ainda que um pagamento de imposto tivesse que ser antecipado, fosse mais vantajosa do que a aquisição posterior à MP, pois a desvantagem da antecipação poderia ser menor que o aumento de preço a ser pago pelos títulos no período seguinte à publicação da norma. Em vista disso e com base no comportamento apresentado pelos retornos nos dias imediatamente anteriores à publicação da MP, como mostrado no Gráfico 8, a data de início do evento adotada será 10 de fevereiro de 2006.

Quanto à duração do evento, o Gráfico 8 também indica a data de 3 de março de 2006 como sendo uma boa possibilidade de final da janela do evento.

A isenção concedida aos estrangeiros tinha como fundamentos o alongamento do perfil da dívida pública e a redução dos juros. Segundo noticiado pela Agência Brasil em 16/02/2006, os investidores "aceitaram uma taxa menor de retorno, após a isenção", de acordo com Joaquim Levy, secretário do Tesouro Nacional na época. De fato, como mostra o gráfico abaixo, é notável a redução dos juros após a entrada em vigor da isenção da MP nº 281/2006. 


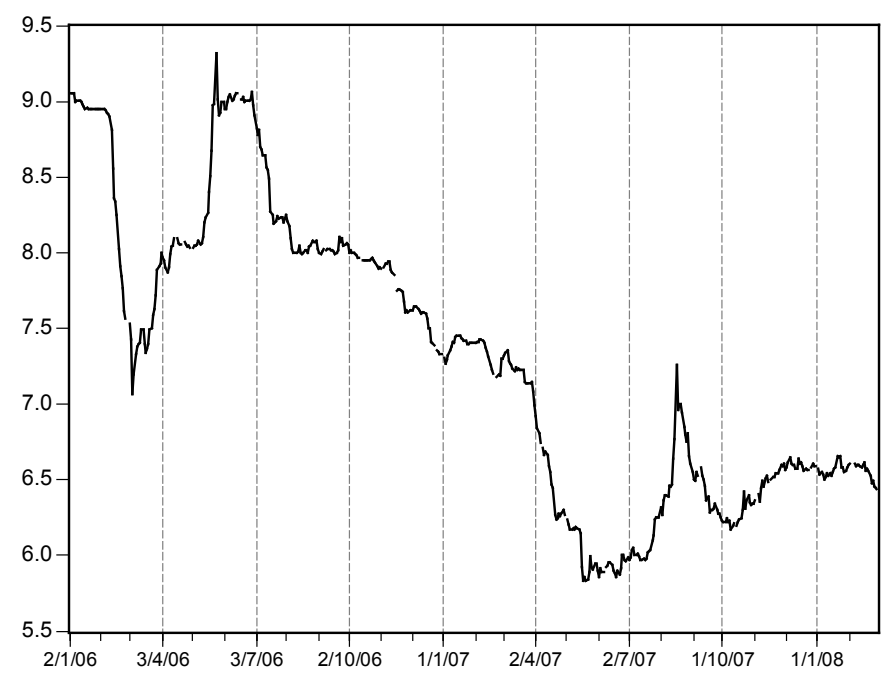

Gráfico 9 - série de retornos de janeiro de 2006 a fevereiro de 2008.

O Gráfico 8 e o Gráfico 9 permitem inferir que o impacto causado pela entrada em vigor da MP pode ser considerado abrupto e duradouro nos seus efeitos sobre os retornos da NTN$\mathrm{B}_{2045}$.

Vandaele (op. cit., p. 335) apresenta treze exemplos de gráficos ilustrativos dos polinômios $\omega(B)$ e $\delta(B)$ (v. Equação 13) aplicados sobre variáveis de intervenção do tipo step e pulse. A representação do impacto abrupto e duradouro proposto por Vandaele (1983, p. 336) é esta:

$$
Y_{t}=\omega S_{t}^{T}
$$

Equação 16 - modelo de intervenção que representa um impacto de início abrupto e de efeito duradouro

A forma geral dada pela Equação 13, portanto, considerando-se que: (i) a parte referente à intervenção é representada pela Equação 16, onde $T=10 / 2 / 2006$, e (ii) a série limpa dos efeitos da intervenção é representada por um modelo ARIMA $(0,1,0)\left(y_{t}=\varepsilon_{t}\right)$, será dada pela seguinte equação:

$$
Z_{t}=\omega S_{t}^{T}+\varepsilon_{t}
$$

Equação 17 - modelo completo (incluída a intervenção) dos retornos diários da NTN-B 2045

Por fim, vale relembrar que a variável step, $S_{t}{ }^{T}$, do modelo de intervenção representa o período que vai de 10/2/2006 a 3/3/2006. 


\subsubsection{Estimação do modelo}

Dada a Equação 17, em que a parte da série anterior à intervenção será representada por um ARIMA $(0,1,0)$, enquanto a intervenção é descrita pela Equação 16, os resultados da estimação do modelo, obtidos pelo SPSS, para o período de 3/1/2005 a 3/3/2006, encontramse abaixo:

Tabela 11 - parâmetros estimados do modelo $\left(Z_{t}=\omega S_{t}^{T}+\varepsilon_{t}\right)$ de retornos da NTN-B ${ }_{2045}(3 / 1 / 2005$ a 3/3/2006)

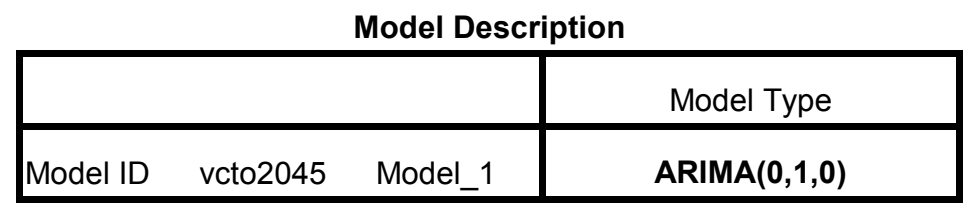

\begin{tabular}{|c|c|c|c|c|c|c|c|c|c|c|c|}
\hline \multicolumn{12}{|c|}{ Model Fit } \\
\hline \multirow[b]{2}{*}{ Fit Statistic } & \multirow[b]{2}{*}{ Mean } & \multirow[b]{2}{*}{ SE } & \multirow[b]{2}{*}{ Minimum } & \multirow[b]{2}{*}{ Maximum } & \multicolumn{7}{|c|}{ Percentile } \\
\hline & & & & & 5 & 10 & 25 & 50 & 75 & 90 & 95 \\
\hline RMSE & ,003 & . & ,003 & ,003 & ,003 & ,003 & ,003 & ,003 & ,003 & ,003 & ,003 \\
\hline MAPE & ,019 & . & ,019 & ,019 & ,019 & ,019 & ,019 & ,019 & ,019 & ,019 & ,019 \\
\hline MaxAPE & ,128 & . & , 128 & ,128 & ,128 & ,128 & ,128 & ,128 & ,128 & ,128 & ,128 \\
\hline MAE & ,002 & . & ,002 & ,002 & ,002 & ,002 & ,002 & ,002 & ,002 & ,002 & ,002 \\
\hline MaxAE & ,012 & . & ,012 & ,012 & ,012 & ,012 & ,012 & ,012 & ,012 & ,012 & ,012 \\
\hline Normalized BIC & $-11,313$ & . & $-11,313$ & $-11,313$ & $-11,313$ & $-11,313$ & $-11,313$ & $-11,313$ & $-11,313$ & $-11,313$ & $-11,313$ \\
\hline
\end{tabular}

ARIMA Model Parameters

\begin{tabular}{|c|c|c|c|c|c|c|c|}
\hline & & & & Estimate & SE & $\mathrm{t}$ & Sig. \\
\hline \multirow[t]{3}{*}{ vcto2045-Model_1 } & vcto2045 & No Transformation & Constant & ,000 & ,000 &,- 827 & ,409 \\
\hline & & & Difference & 1 & & & \\
\hline & $S_{t}^{T}$ & No Transformation & $(\omega)$ &,- 113 & ,001 & $-93,432$ &, 000 \\
\hline
\end{tabular}

Observa-se que o parâmetro da variável de intervenção $(\omega)$ é bastante significativo estatisticamente. Dessa forma, a série de retornos das NTN-B 2045 , do período de 3/1/2005 a 3/3/2006, é descrita pelo seguinte modelo (erro-padrão entre parênteses):

$$
\begin{gathered}
Y_{t}=-0,113 S_{t}^{T}+\varepsilon_{t} \\
(0,001)
\end{gathered}
$$

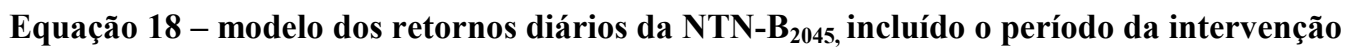




\subsubsection{Adequação do modelo}

A análise dos resíduos deve indicar, caso o modelo seja adequado, que eles são um ruído branco, isto é, devem possuir média zero, variância constante e não devem ser autocorrelacionados ao longo do tempo.

O teste de médias revelou que não se pode rejeitar a hipótese de que a média dos resíduos seja igual a zero $(p=1)$. Para efetuar os testes de se a média e a variância dos resíduos são constantes ao longo do período amostrado, dividiu-se a amostra em duas e testaram-se as hipóteses de igualdade de médias e variâncias de ambas as subamostras. Os resultados dos testes de igualdade de médias e de variâncias das subamostras encontram-se abaixo:

Tabela 12 - teste de igualdade de média das duas subamostras dos retornos díários da NTN-B 2045 Test for Equality of Means Between Series

Sample: 3/01/2005 3/03/2006

Included observations: 305

\begin{tabular}{lrrr}
\hline \hline Method & df & Value & Probability \\
\hline \hline t-test & 291 & 1.155442 & 0.2489 \\
Anova F-statistic & $(1,291)$ & 1.335047 & 0.2489 \\
\hline \hline
\end{tabular}

Analysis of Variance

\begin{tabular}{lrrr}
\hline \hline Source of Variation & df & Sum of Sq. & Mean Sq. \\
\hline \hline Between & 1 & $9.64 \mathrm{E}-06$ & $9.64 \mathrm{E}-06$ \\
Within & 291 & 0.002101 & $7.22 \mathrm{E}-06$ \\
\hline \hline Total & 292 & 0.002111 & $7.23 \mathrm{E}-06$ \\
\hline \hline
\end{tabular}

Category Statistics

\begin{tabular}{c|rrrr}
\hline \hline Variable & Count & Mean & Std. Dev. & $\begin{array}{r}\text { Std. Err. } \\
\text { of Mean }\end{array}$ \\
\hline SER01 & 145 & 0.000183 & 0.002803 & 0.000233 \\
SER02 & 148 & -0.000180 & 0.002568 & 0.000211 \\
\hline All & 293 & $-3.17 \mathrm{E}-09$ & 0.002689 & 0.000157 \\
\hline \hline
\end{tabular}


Tabela 13 - teste de igualdade de variância das duas subamostras dos retornos díários da NTN-B 2045 Test for Equality of Variances Between Series Sample: 3/01/2005 3/03/2006

Included observations: 305

\begin{tabular}{lrrr}
\hline \hline Method & df & Value & Probability \\
\hline \hline F-test & $(147,144)$ & 1.191321 & 0.2926 \\
Siegel-Tukey & 1 & 0.825364 & 0.4092 \\
Bartlett & & 1.110096 & 0.2921 \\
Levene & $(1,291)$ & 0.004033 & 0.9494 \\
Brown-Forsythe & $(1,291)$ & 0.008993 & 0.9245 \\
& & & \\
\hline \hline
\end{tabular}

Category Statistics

\begin{tabular}{c|rrrrr}
\hline \hline & & & Mean Abs. & Mean Abs. & Mean Tukey- \\
Variable & Count & Std. Dev. & Mean Diff. & Median Diff. & Siegel Rank \\
\hline SER01 & 145 & 0.002803 & 0.001695 & 0.001693 & 151.1278 \\
SER02 & 148 & 0.002568 & 0.001711 & 0.001670 & 142.9558 \\
\hline All & 293 & 0.002689 & 0.001703 & 0.001682 & 147.0000 \\
\hline \hline
\end{tabular}

Bartlett weighted standard deviation: 0.002687

Os testes estatísticos mostrados nas tabelas acima indicam que não se podem rejeitar as hipóteses de igualdade de médias e das variâncias das subamostras. Isso significa que a média dos resíduos é zero ao longo de toda a amostra, assim como a variância dos resíduos também é a mesma no tempo amostrado.

Para concluir se os resíduos são um ruído branco, falta apenas testar suas as autocorrelações. As saídas relativas às correlações dos resíduos são mostradas abaixo:

Tabela 14 - estatísticas do modelo $Z_{t}=\omega S_{t}^{T}+\varepsilon_{t}$

Model Statistics

\begin{tabular}{|l|c|c|c|c|c|c|}
\hline \multirow{2}{*}{ Model } & \multirow{2}{*}{$\begin{array}{c}\text { Model Fit } \\
\text { statistics }\end{array}$} & \multicolumn{2}{|c|}{ Ljung-Box Q(18) } & \multirow{2}{*}{ Number of } \\
\cline { 3 - 7 } & $\begin{array}{c}\text { Number of } \\
\text { Predictors }\end{array}$ & $\begin{array}{c}\text { Stationary R- } \\
\text { squared }\end{array}$ & Statistics & DF & Sig. & Outliers \\
\hline vcto2045-Model_1 & 1 &, 994 & 11,151 & 18 &, 888 & 21 \\
\hline
\end{tabular}




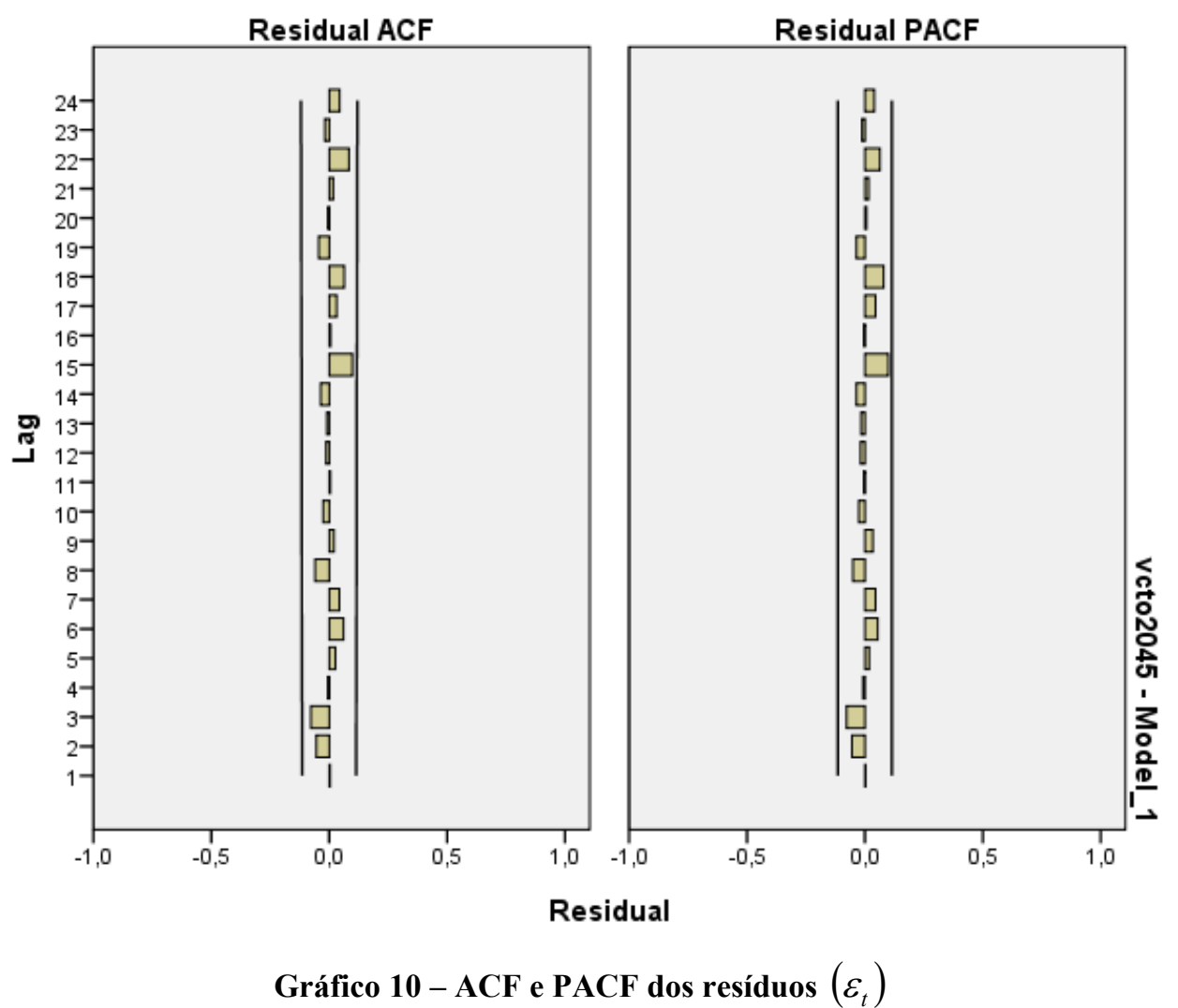

O teste de Ljung-Box apresentado na Tabela 14 indica que não se pode rejeitar a hipótese de ausência de autocorrelação dos resíduos, ou seja, os resíduos apresentam características de um ruído branco. Essa evidência é corroborada pelas funções de autocorrelação e autocorrelação parcial apresentadas no Gráfico 10, as quais indicam que as autocorrelações dos resíduos não são significativamente diferentes de zero. Em outras palavras, os erros não apresentam qualquer tipo de estrutura que o modelo não tenha captado. Os testes dos resíduos, enfim, evidenciam que os resíduos gerados pelo modelo especificado são um ruído branco.

\subsubsection{Análise dos resultados}

A interpretação do modelo é que, provavelmente em virtude da proximidade da entrada em vigor da MP que isentou de imposto de renda os rendimentos produzidos por títulos públicos brasileiros adquiridos por estrangeiros, notadamente as NTN-B, houve uma perda de cerca de $11 \%$ no retorno pré-imposto das NTN-B 2045 negociadas no mercado secundário no período de $10 / 2 / 2006$ a $3 / 3 / 2006$. 
Não se pode afirmar categoricamente que a redução do retorno foi causada pela MP $n^{0}$ 281/2006. Outros eventos podem ter, coincidentemente, contribuído de forma a reduzir, naquele exato momento, o retorno da NTN-B. Os determinantes da taxa de retorno de títulos são vários e obtê-los está fora do escopo deste estudo. No entanto, conforme Harfuch (2008, p. 146), o principal determinante da taxa de juros no Brasil no período pós-Plano Real (a partir de 1995) passou a ser a percepção do investidor estrangeiro acerca do risco de default do país.

Apesar de haver outros indicadores representativos do risco-país, o EMBI+, Emerging Markets Bond Index Plus, calculado pelo J. P. Morgan Chase, é um dos mais utilizados (BANCO CENTRAL, 2006, p. 14). A MP foi concebida para melhorar simultaneamente vários fundamentos macroeconômicos, como alongamento do perfil da dívida, redução dos juros e do risco-país. De fato, quando a NTN-B trocou de mãos, ou seja, no momento em que o estrangeiro entrou maciçamente, houve correlação entre o movimento do retorno da NTN-B (declínio) e o movimento do risco-país (redução).

Haja vista que muitas variáveis endógenas, como taxa de juros, câmbio e risco-país, foram afetadas pela $\mathrm{MP}^{26}$, é aconselhável que se compare o risco-Brasil com o risco de outros países, que obviamente não foram afetados pela MP. Se o risco-Brasil tiver se "descolado" do risco dos demais países à época da edição da MP - no sentido de que o risco-Brasil melhorou comparativamente a outros países -, passa a existir uma forte evidência de que a isenção concedida aos estrangeiros reduziu os retornos das NTN-B.

Segundo estudo do Instituto de Pesquisa Econômica Aplicada (2006, p. 94), IPEA, 24 países representavam, em dezembro de 2005, perto de $98 \%$ da capitalização de mercado do Emerging Markets Bond Index Global, EMBIG, índice elaborado pelo J. P. Morgan. Como o intuito aqui é dar evidências de que a MP foi a responsável pela queda dos retornos das NTNB e não o de construir um modelo que determine os fatores que afetam o spread pago pelos países emergentes em decorrência da sua vulnerabilidade a choques externos, como o caso do estudo do IPEA, será comparado o EMBI+ do Brasil com os EMBI+ de México, Rússia,

\footnotetext{
${ }^{26}$ como revela reportagem do Valor Econômico de 16/2/2006: "Segundo Mercadante, somente o anúncio de que a medida [isenção para estrangeiros] estava sendo estudada pelo governo fez a taxa de juros futura ceder".
} 
Turquia, Venezuela e Filipinas, que, em conjunto com o Brasil, representavam cerca de 70\% do EMBIG no final de 2005.

Abaixo, apresentam-se os gráficos, dos três primeiros meses de 2006, da relação entre o $\mathrm{EMBI}+$ do Brasil e os EMBI+ dos cinco outros países escolhidos.

Brasil/Méx

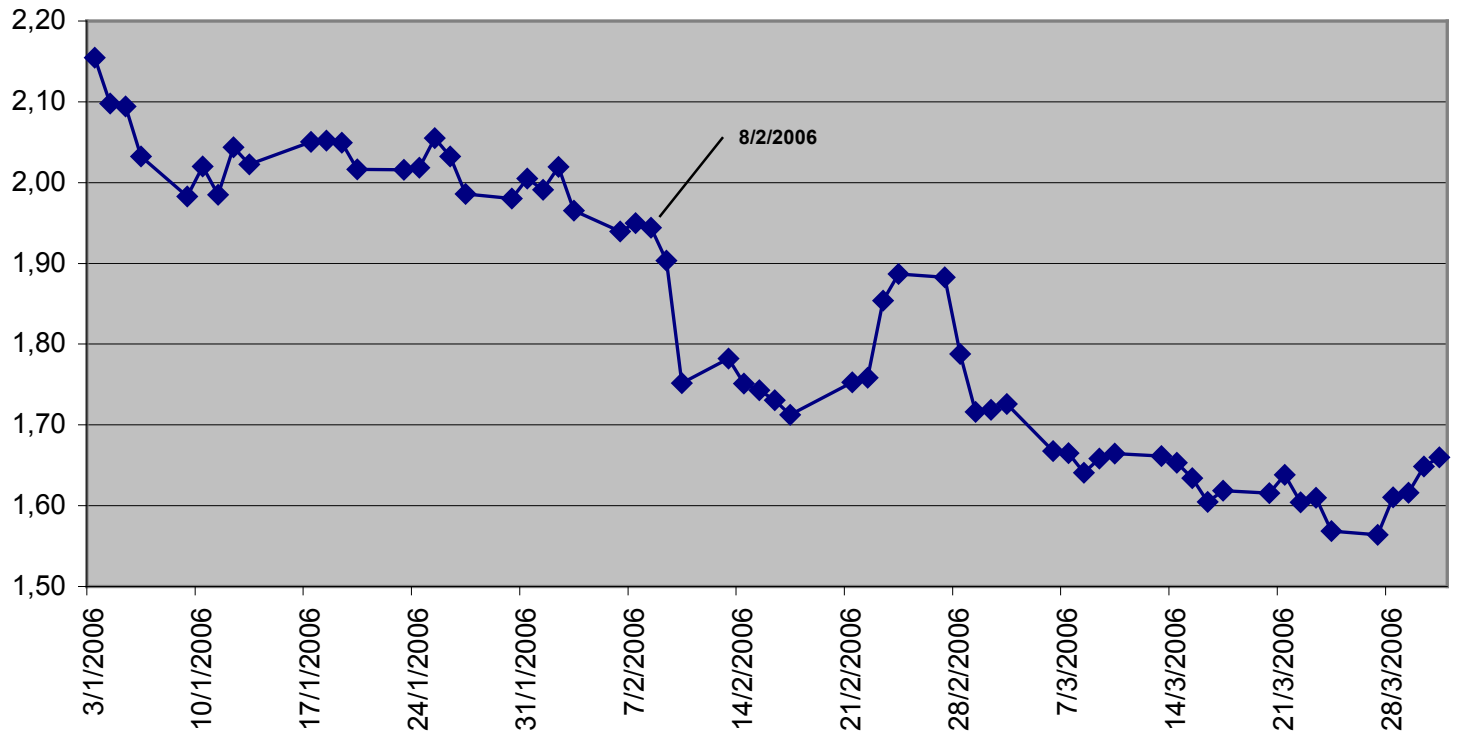

Gráfico 11 - Relação entre EMBI-Brasil e EMBI-México, de janeiro a março de 2006.

Brasil/Rus

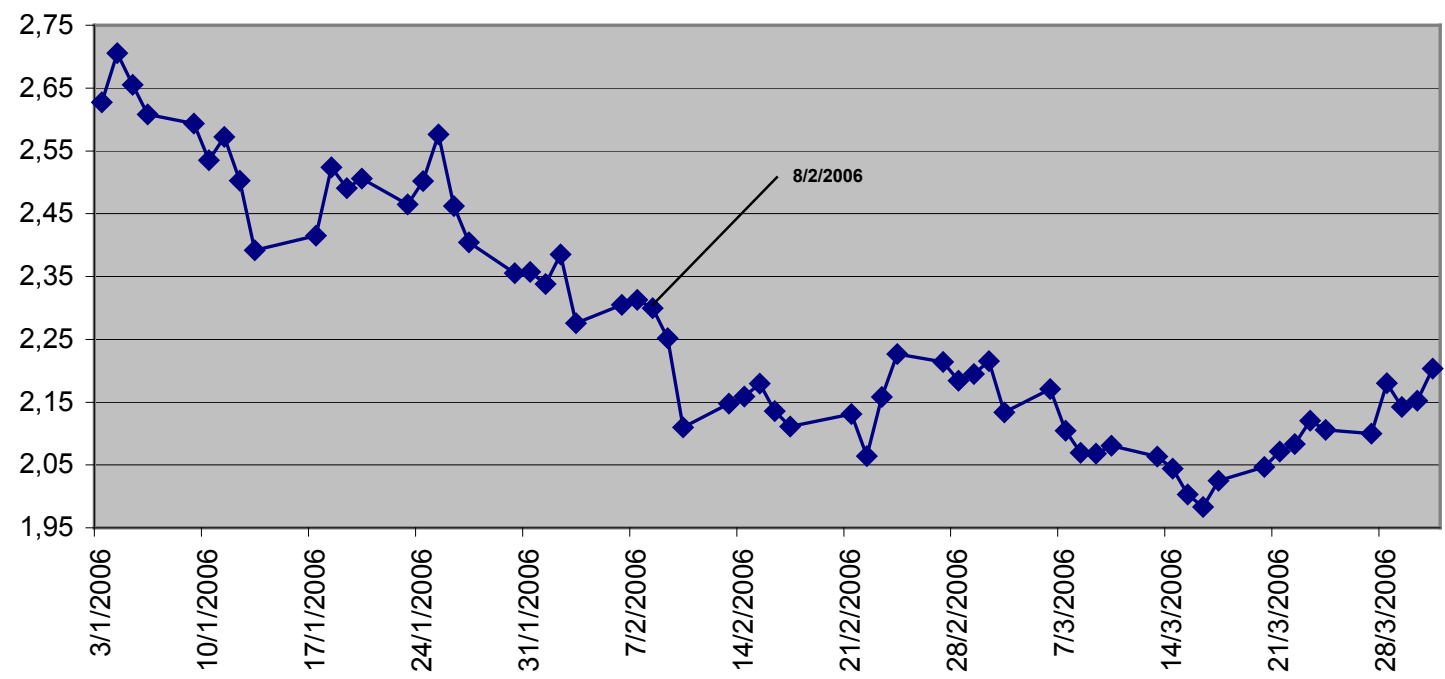

Gráfico 12 - relação entre EMBI-Brasil e EMBI-Rússia, de janeiro a março de 2006. 


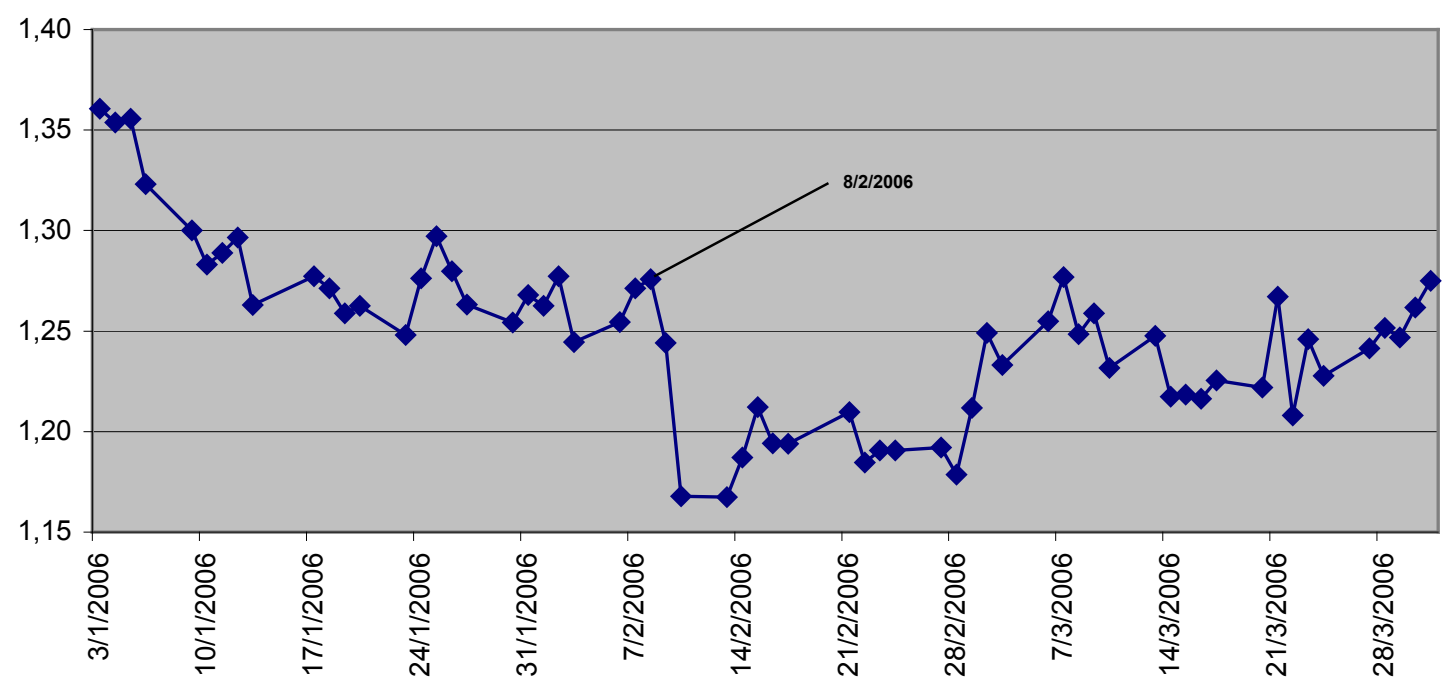

Gráfico 13 - relação entre EMBI-Brasil e EMBI-Turquia, de janeiro a março de 2006.

Brasil/Venez

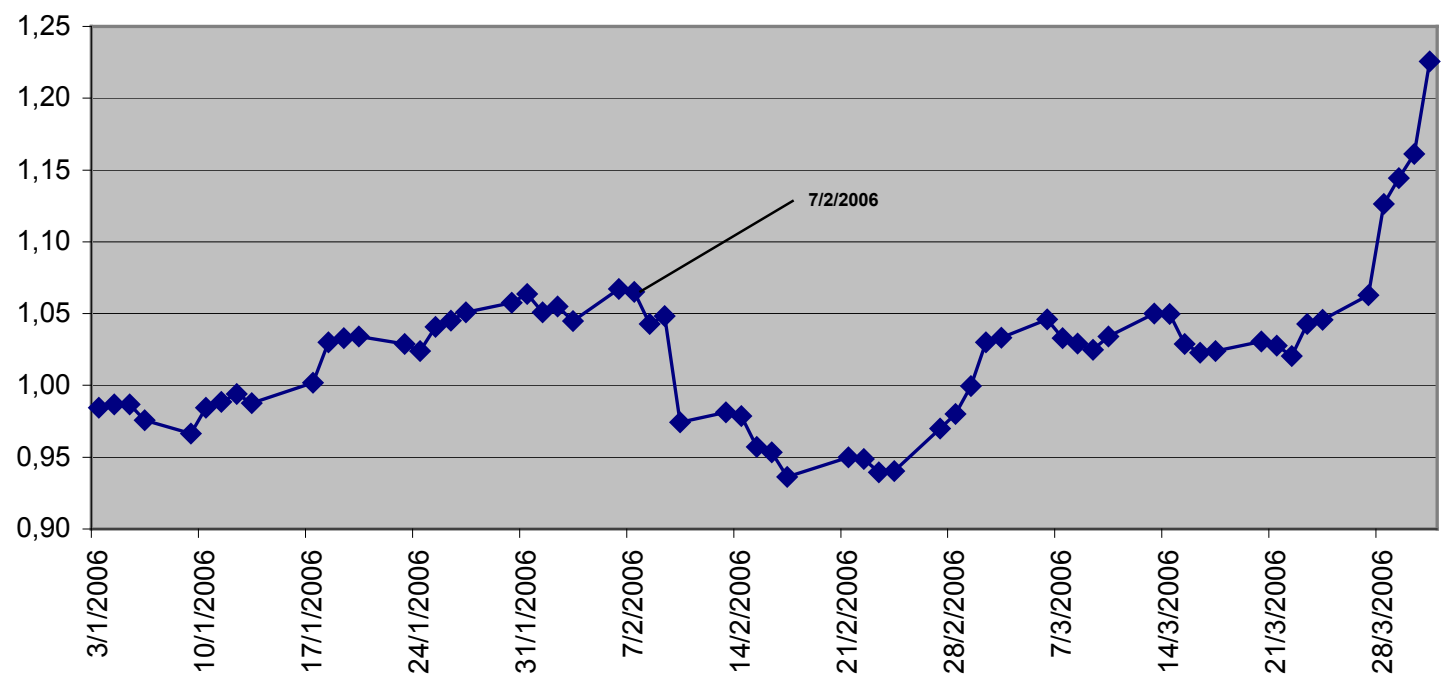

Gráfico 14 - relação entre EMBI-Brasil e EMBI-Venezuela, de janeiro a março de 2006. 
Brasil/Filip

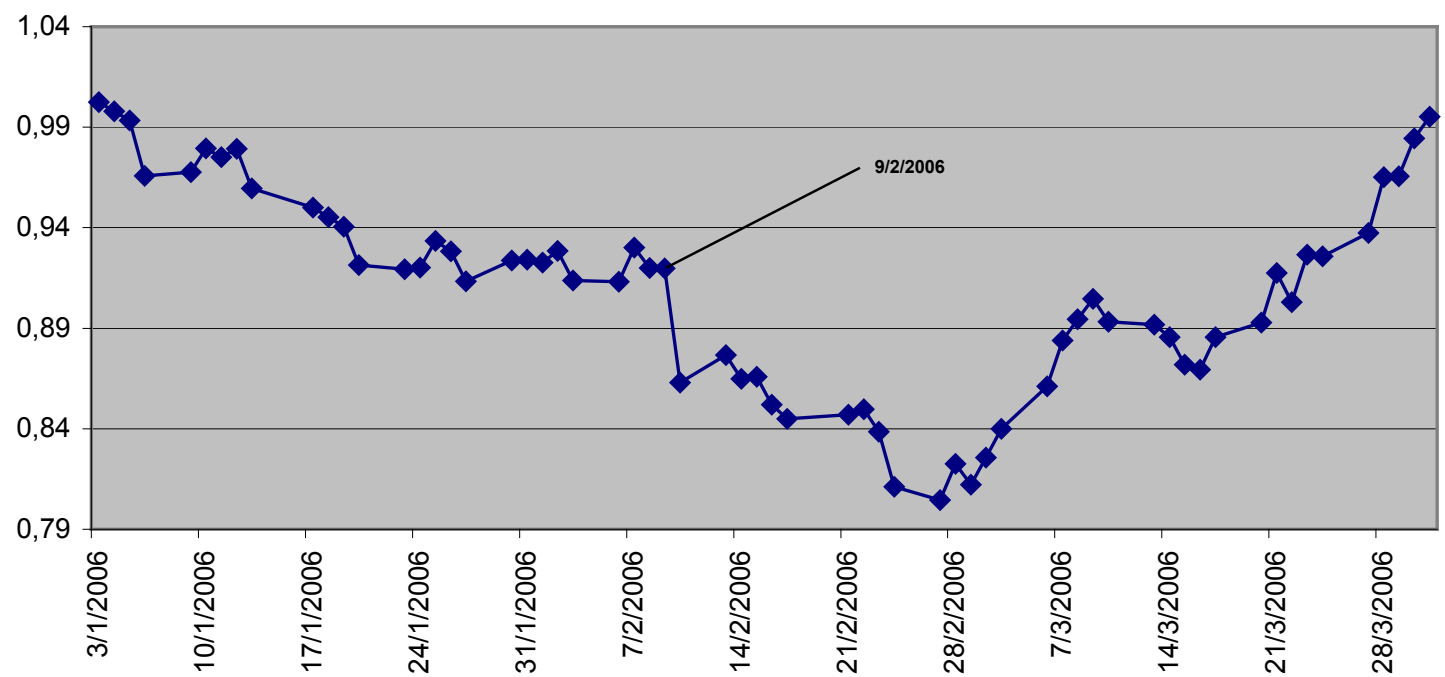

Gráfico 15 - relação entre EMBI-Brasil e EMBI-Filipinas, de janeiro a março de 2006.

Os gráficos acima indicam que houve uma queda brusca ao redor do dia $8 / 2 / 2006$, data muito próxima à data eleita como representativa do início do evento da MP para fins da análise de intervenção (v. Gráfico 8). Em todos os gráficos, ficou evidente que houve um evento que afetou apenas o Brasil, após o qual o risco-Brasil se reduziu em relação aos outros e, passado um certo tempo, ganhou fôlego novamente. A simples análise gráfica reforça o argumento de que a redução do risco-país apresentada pelo Brasil, comparativamente aos países amostrados, deu-se provavelmente em virtude da MP nº 281/2006.

A fim de dar ainda mais robustez à probabilidade de que a queda dos retornos da NTN-B 2045 foi decorrente da MP $\mathrm{n}^{\mathrm{o}}$ 281/2006, foram feitos testes adicionais em que se procura demonstrar que o risco-Brasil foi o único a ser afetado significativamente uma semana antes da entrada em vigor da MP, data coincidente com a queda de retorno da NTN-B 2045 . Para tanto, utilizaram-se as séries temporais dos EMBI+ dos seis países (Brasil, México, Rússia, Turquia, Venezuela e Filipinas) e verificou-se se houve alguma quebra estrutural ao longo dos três primeiros meses do ano de 2006 .

O SPSS possui uma rotina que detecta os outliers das séries temporais. Entre os tipos de outliers detectados por esse software estatístico, o interesse particular aqui recai sobre o outlier representativo da mudança significativa da declividade da série. Literalmente, o SPSS define um outlier de declividade como: "Level shift. An outlier that shifts all observations by 
a constant, starting at a particular series point. A level shift could result from a change in policy". A formulação desse tipo de outlier é apresentada pelo SPSS como se segue. Dada uma série temporal $Y(t)=U(t)+\omega S_{T}(t)$, onde $S_{T}(t)=\frac{1}{1-B} I_{t}(t), S_{T}(t)$ assume o valor 0 se $(\mathrm{t}<$ $\mathrm{T})$ e 1 se $(\mathrm{t} \geq \mathrm{T})$. Note-se que a função que representa o level shift outlier é precisamente uma função pulso, como desenvolvido no item que explicava a análise de intervenção (4.2.4). Isso significa que o SPSS faz uma análise de intervenção para detectar os outliers de declividade.

Os gráficos dos EMBI de cada país estão abaixo apresentados, seguidos das tabelas geradas pelo SPSS, que indicam os outliers de declividade detectados em cada série histórica (três primeiros meses do ano de 2006).

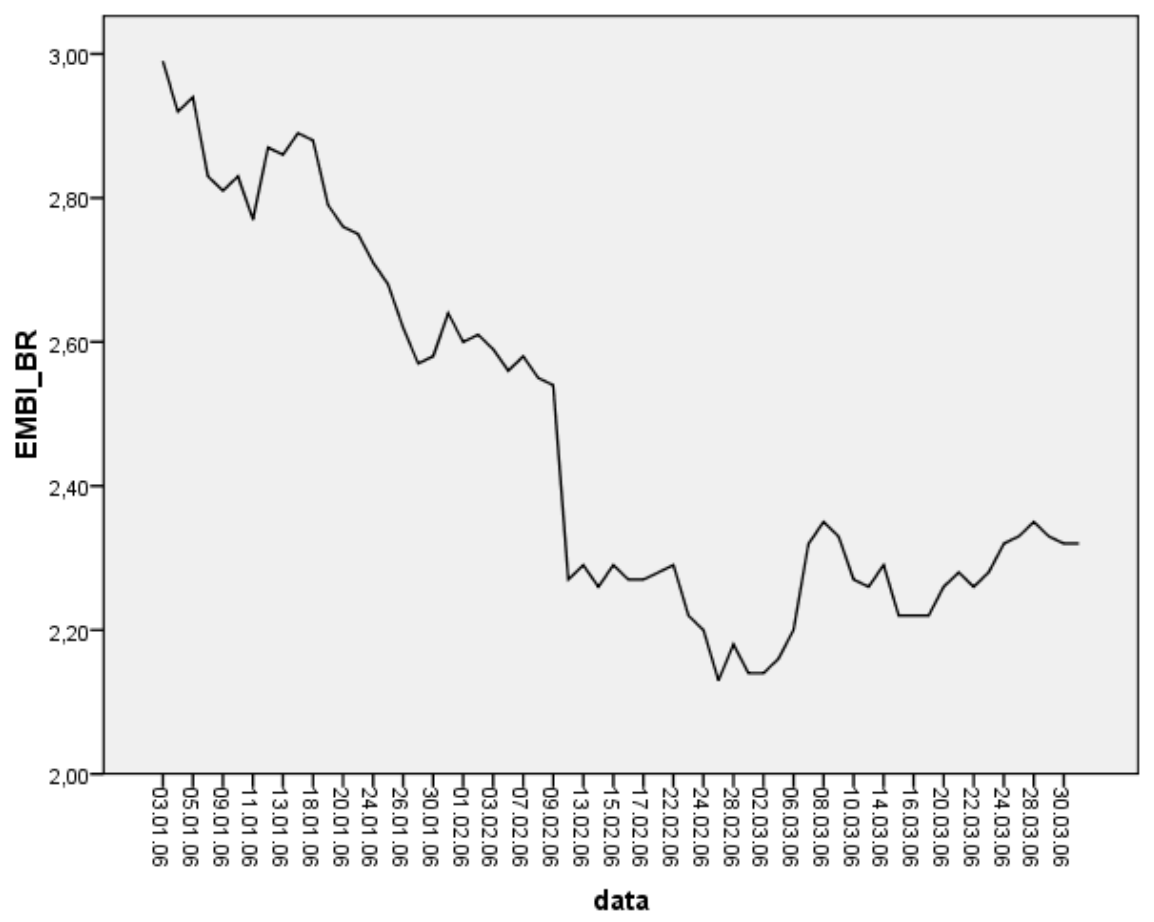

Gráfico 16 - EMBI+ Brasil 


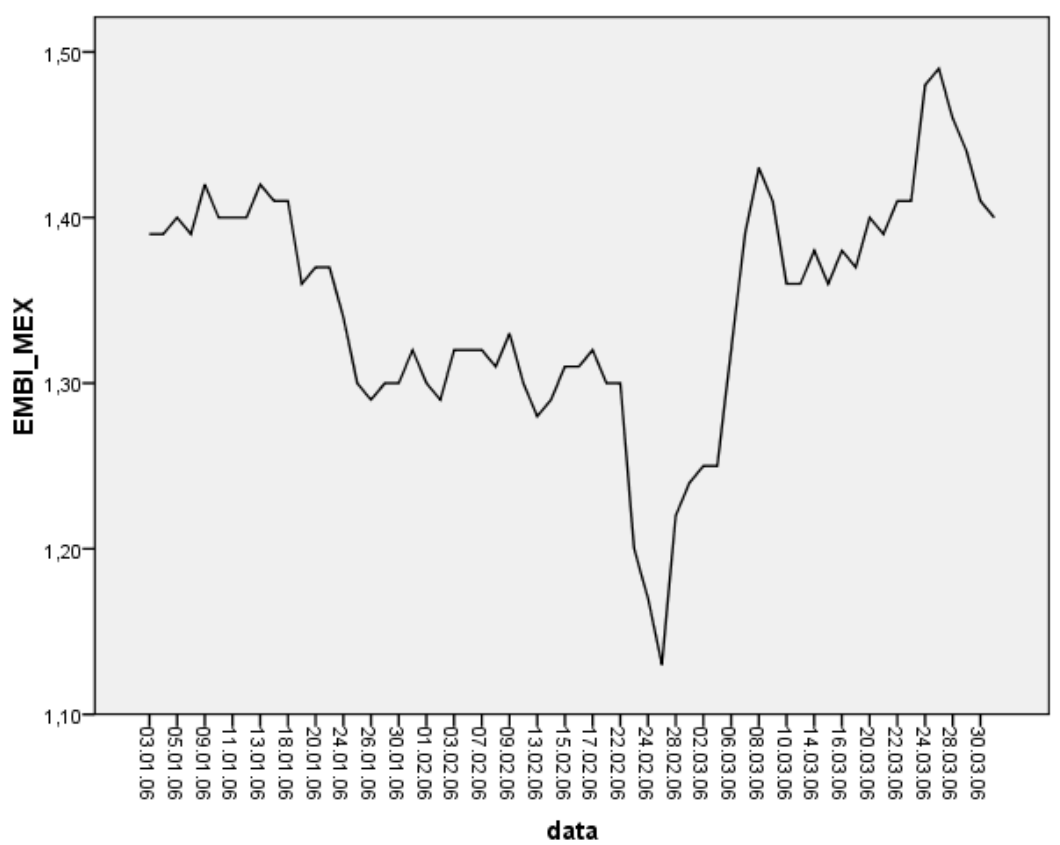

Gráfico 17 - EMBI+ México

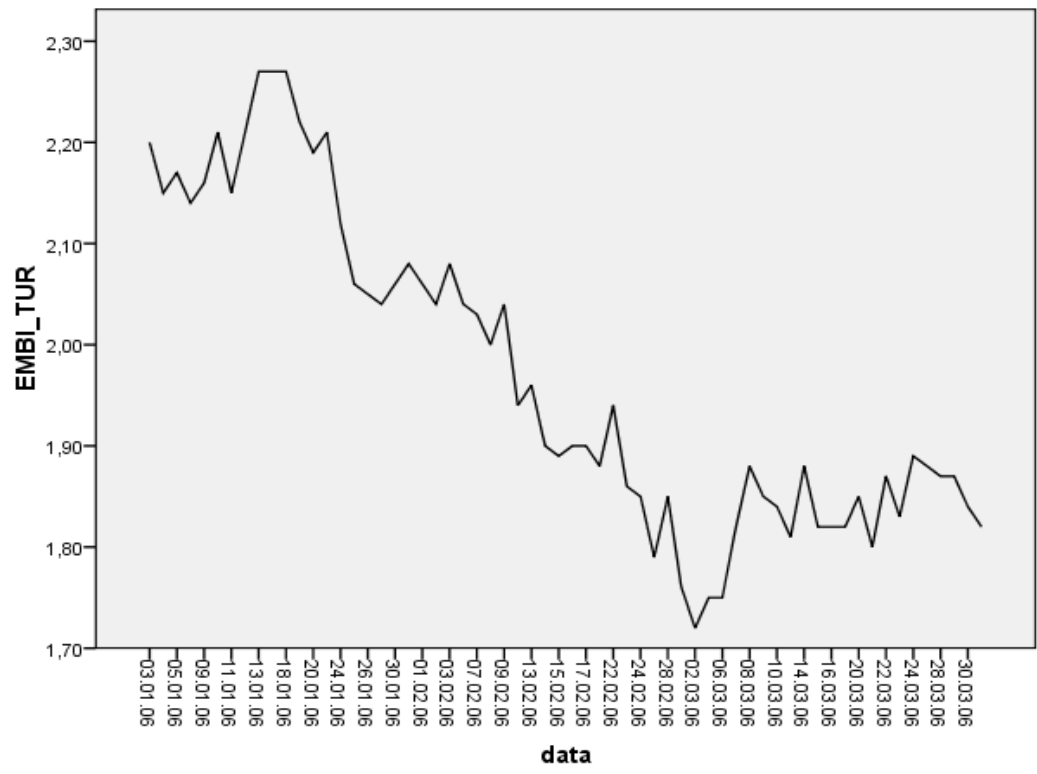

Gráfico 18 - EMBI+ Turquia 


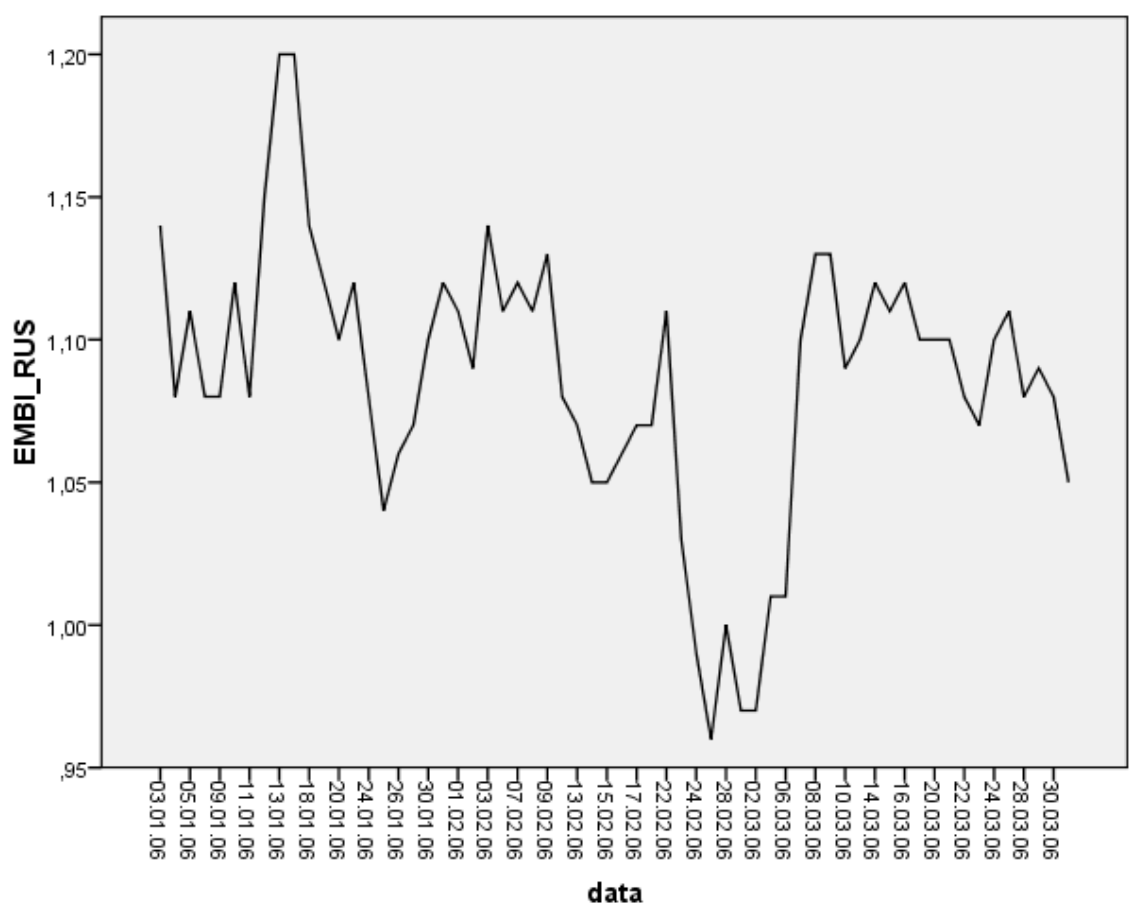

Gráfico 19 - EMBI+ Rússia

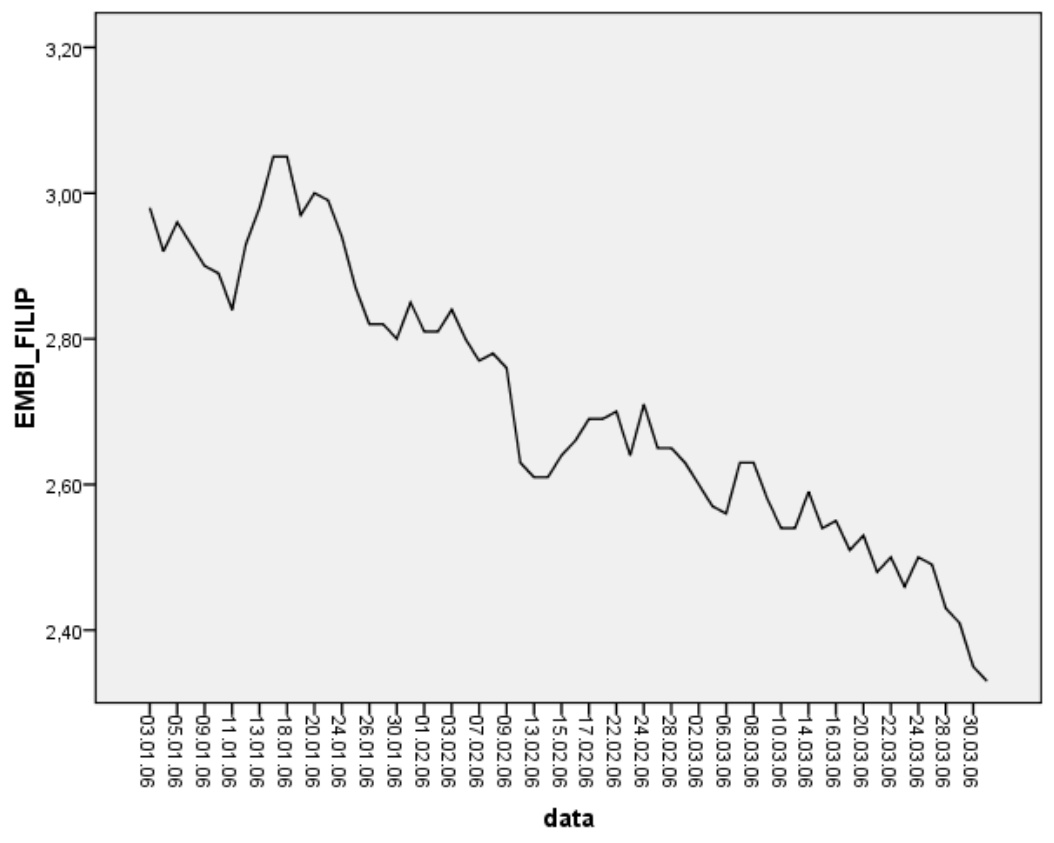

Gráfico 20 - EMBI+ Filipinas 


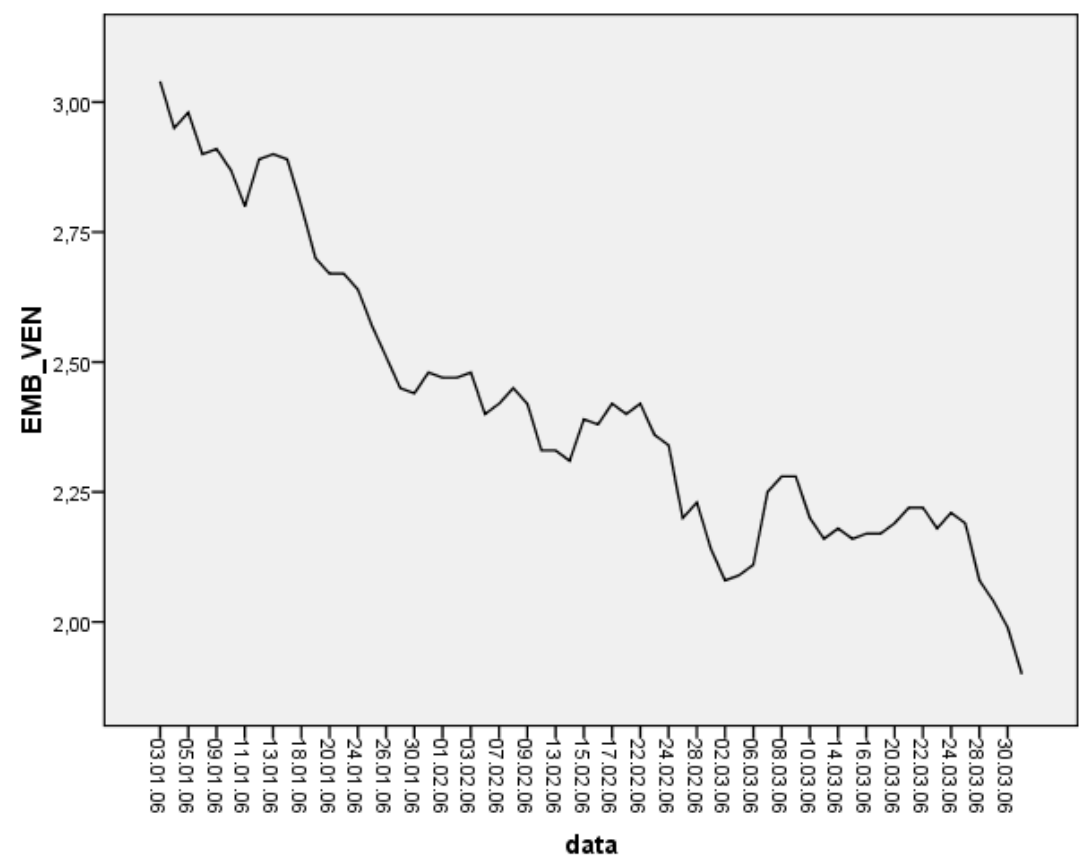

Gráfico 21 - EMBI+ Venezuela

Tabela 15 - Outliers level shift detectados nos EMBI+ de janeiro a março de 2006

\begin{tabular}{lcccccc}
\hline & $N^{o}$ de outliers & Observação & Estimate & $S E$ & $t$ & Sig. \\
\hline \multirow{2}{*}{ EMBI-Brasil } & 2 & $\mathbf{1 0 / 2 / 2 0 0 6}$ & $\mathbf{- 0 , 2 7 0}$ & $\mathbf{0 , 0 4 0}$ & $\mathbf{- 6 , 5 9 6}$ & $\mathbf{0 , 0 0 0}$ \\
& & $7 / 3 / 2006$ & 0,129 & 0,040 & 3,253 & 0,002 \\
\hline EMBI-Venezuela & 1 & $7 / 3 / 2006$ & 0,161 & 0,049 & 3,310 & 0,002 \\
EMBI-México & 1 & $23 / 2 / 2006$ & $-0,100$ & 0,026 & $-3,897$ & 0,000 \\
EMBI-Turquia & 0 & & & & & \\
EMBI-Rúsia & 0 & & & & & \\
EMBI-Filipinas & 0 & & & & & \\
\hline
\end{tabular}

Observa-se que apenas o Brasil teve o seu EMBI afetado significativamente exatamente na data do início do evento, mais precisamente em 10/2/2006, quando o risco-Brasil caiu 27\% (e o retorno da NTN-B 2045 caiu mais bruscamente). Os outros outliers detectados (Brasil e Venezuela, positivos e afastados do início do evento; México, negativo mas também afastado; Turquia, Rússia e Filipinas não tiveram outliers de declividade detectados no período) não parecem ter relação com a entrada em vigor da MP.

Fornecidos indícios de que o evento MP 281/2006 foi o provável responsável pela redução dos retornos da NTN-B 2045 , observou-se que, ao entrar no mercado secundário o estrangeiro sofreu uma perda de retorno bastante expressiva (11\%), o que é uma evidência de que o investidor nacional era o investidor marginal do papel naquele período. A edição de 
25/5/2006 do Valor Econômico trazia um comentário sobre quem era o principal detentor da NTN-B:

Até a entrada dos investidores estrangeiros, essas NTNs-B eram vendidas principalmente para fundos de pensão nacionais, que têm como característica segurar os papéis até o vencimento, para honrar compromissos de longo prazo com seus associados. Junto com os estrangeiros, entraram também investidores nacionais mais agressivos, interessados em lucrar com a rápida valorização do papel, provocada pelo súbito aumento de demanda.

Houve, portanto, um tributo implícito "pago" pelo investidor estrangeiro ao investidor nacional que se desfez das $\mathrm{NTN}^{-B_{2045}}$ nas negociações realizadas no mercado secundário.

Esse pagamento se dá, no mercado secundário, por via do aumento de preço, ocorrido em resposta ao aumento da demanda pelo título. Se o investidor brasileiro tinha um título de valor $\$ p$ que lhe rendia $\$ r$, então o seu retorno era dado por $r / p$. Quando esse investidor brasileiro se desfez do papel, em resposta ao aumento de preço causado pela demanda dos estrangeiros, o retorno obtido pelo estrangeiro comprador, na hipótese de um aumento de preço $(\Delta p>0)$, passou a ser de $[r /(p+\Delta p)]<r / p$.

\subsubsection{NTN-B 2033}

Como para a NTN-B 2045 , o primeiro passo na modelagem dos retornos diários da NTN-B 2033 é obter o modelo ARIMA que reflita adequadamente o processo gerador dos dados. O exame do gráfico dos retornos da NTN-B 2033 permite visualizar a ausência de estacionariedade da série, bem como o período, em fevereiro de 2006, em que ocorreu a queda brusca dos retornos: 


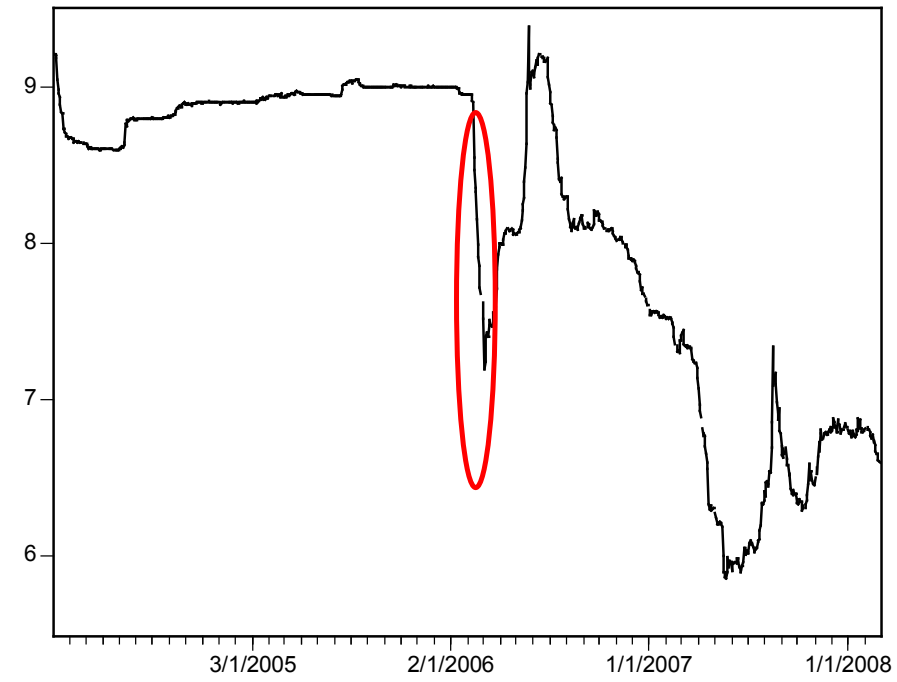

Gráfico 22 - série de retornos diários da NTN-B ${ }_{2033}$ de 2/1/2004 a 28/2/2008

O gráfico das primeiras diferenças, abaixo, indica uma mudança significativa das variâncias a partir do início de 2006.

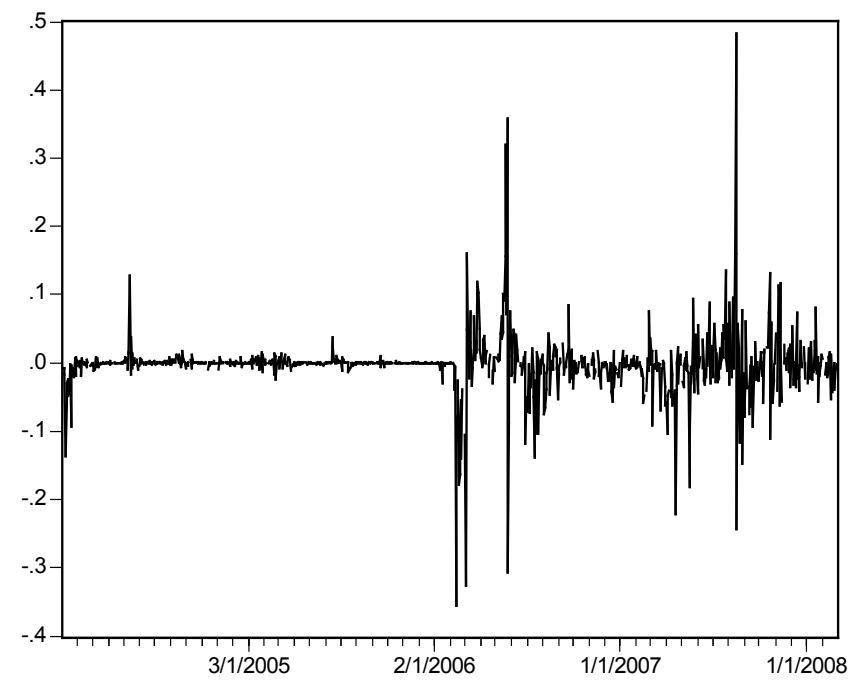

Gráfico 23 - primeiras diferenças dos retornos NTN-B 2033

A inconstância da variância ao longo do tempo é uma evidencia de que a série diferenciada também não é estacionária. Por isso, à semelhança da amostra selecionada para a NTN-B 2045 , as observações utilizadas para a identificação do processo gerador dos retornos da NTN-B 2033 serão as de um período anterior à intervenção. O período escolhido, com base no Gráfico 24, abaixo, foi o de 1/4/2005 a 10/2/2006, um total de 290 observações: 


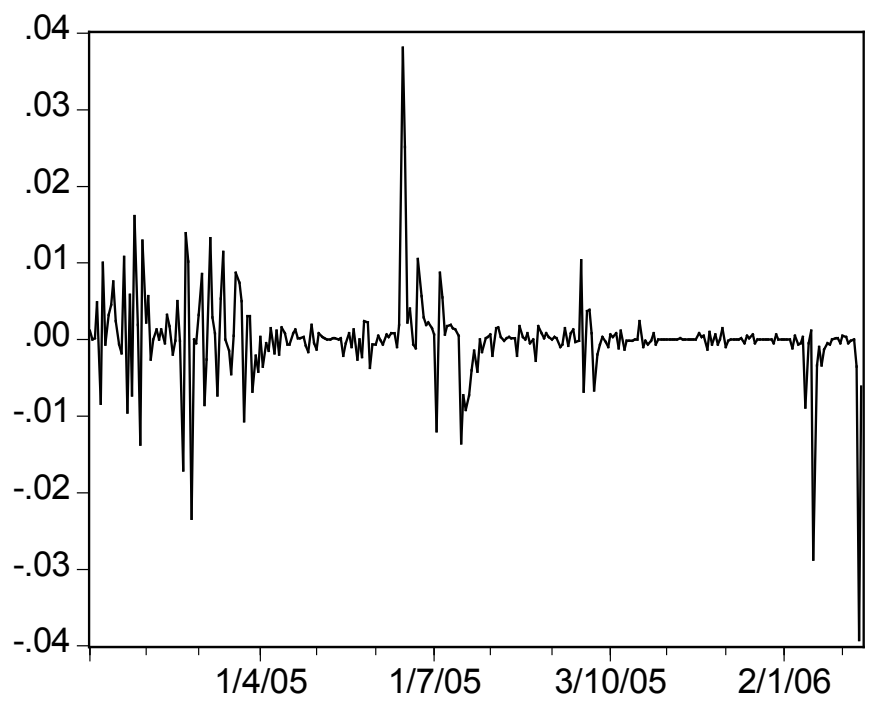

Gráfico 24 - primeiras diferenças retornos NTN-B 2033 , período de 3/1/2005 a 10/2/2006

O evento, baseado no Gráfico 25, abaixo, terá seu início arbitrado para 13/2/2006 e término para 3/3/2006.

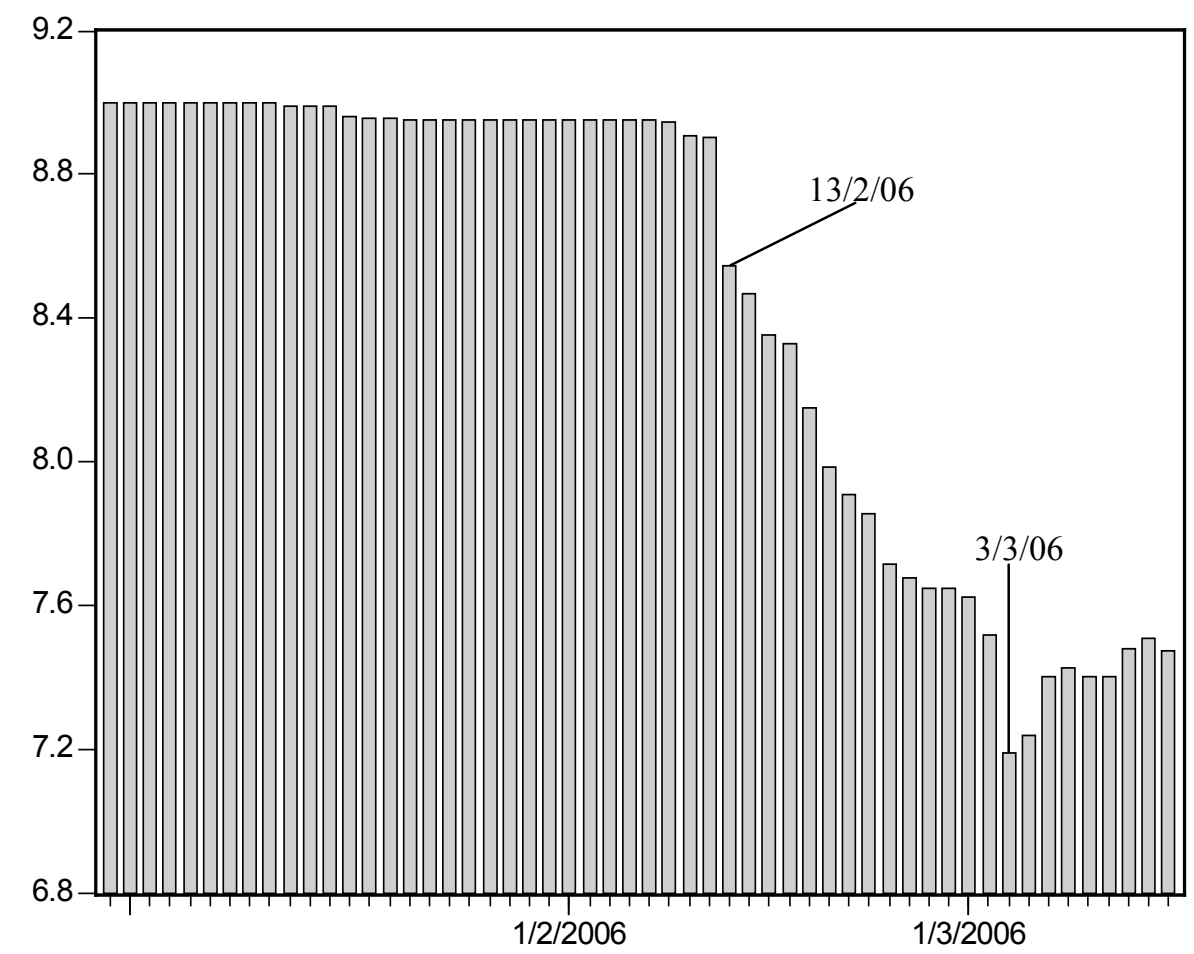

Gráfico 25 - retornos da NTN-B ${ }_{2033}$, de janeiro de 2006 a meados de fevereiro de 2006

O teste de Dickey e Pantula rejeitou a hipótese de existência de até três raízes unitárias na série diferenciada. O correlograma indicou que o modelo para a fase pré-intervenção poderia ser um AR(1). Essa indicação foi confirmada tanto pelo SPSS quanto pelo Eviews. Vale 
relembrar que um modelo $\mathrm{AR}(1)$ é descrito pela Equação 5, que, para o período limpo, foi estimada por $y_{t}=0,295 y_{t-1}+\varepsilon_{t}$, sendo que o erro padrão do parâmetro autorregressivo é igual a $(0,064)$, portanto o parâmetro é significativo estatisticamente $(\mathrm{t}=4,617320)$.

O Gráfico 25 dá mostras de que a intervenção, semelhantemente à NTN-B 2045 , teve um início abrupto e permanente. A Equação 16, de novo, modela a parte da intervenção,

A forma geral dada pela Equação 13 é particularizada para as NTN-B 2033 por:

$$
Z_{t}=\omega S_{t}^{T}+\theta_{1} Z_{t-1}+\varepsilon_{t}
$$

Equação 19 - modelo completo (incluída a intervenção) dos retornos diários da NTN-B ${ }_{2033}$

A Equação 19 foi estimada pelo SPSS, que forneceu os seguintes resultados:

Tabela 16 - estatísticas e parâmetros da NTN-B 2033

\begin{tabular}{|lll|l|}
\hline & Model Description \\
\hline & & Model Type \\
\hline Model ID & vcto2033 & Model_1 & ARIMA $(1,1,0)$ \\
\hline
\end{tabular}

\section{Model Statistics}

\begin{tabular}{|l|c|c|c|c|c|c|}
\hline \multirow{2}{*}{} & \multirow{2}{*}{ Model } & \multicolumn{2}{c|}{$\begin{array}{c}\text { Model Fit } \\
\text { statistics }\end{array}$} & \multicolumn{2}{|c|}{ Ljung-Box Q(18) } & \multirow{2}{*}{$\begin{array}{c}\text { Number of } \\
\text { Outliers }\end{array}$} \\
\cline { 3 - 7 } & $\begin{array}{c}\text { Number of } \\
\text { Predictors }\end{array}$ & $\begin{array}{c}\text { Stationary R- } \\
\text { squared }\end{array}$ & Statistics & DF & Sig. & 23 \\
\hline vcto2033-Model_1 & 1 &, 999 & 24,991 & 17 &, 095 & 23 \\
\hline
\end{tabular}

ARIMA Model Parameters

\begin{tabular}{|c|c|c|c|c|c|c|c|c|}
\hline & & & & & Estimate & SE & $\mathrm{t}$ & Sig. \\
\hline \multirow[t]{4}{*}{ vcto2033-Model_1 } & vcto2033 & No Transformation & Constant & \multirow{3}{*}{$\operatorname{Lag} 1$} & ,000 & ,000 & $-1,124$ & ,262 \\
\hline & & & & &, 539 & ,064 & 8,359 & ,000 \\
\hline & & & Difference & & 1 & & & \\
\hline & $S_{t}^{T}$ & No Transformation & \multicolumn{2}{|l|}{$(\omega)$} &,- 116 & ,001 & $-91,074$ &, 000 \\
\hline
\end{tabular}




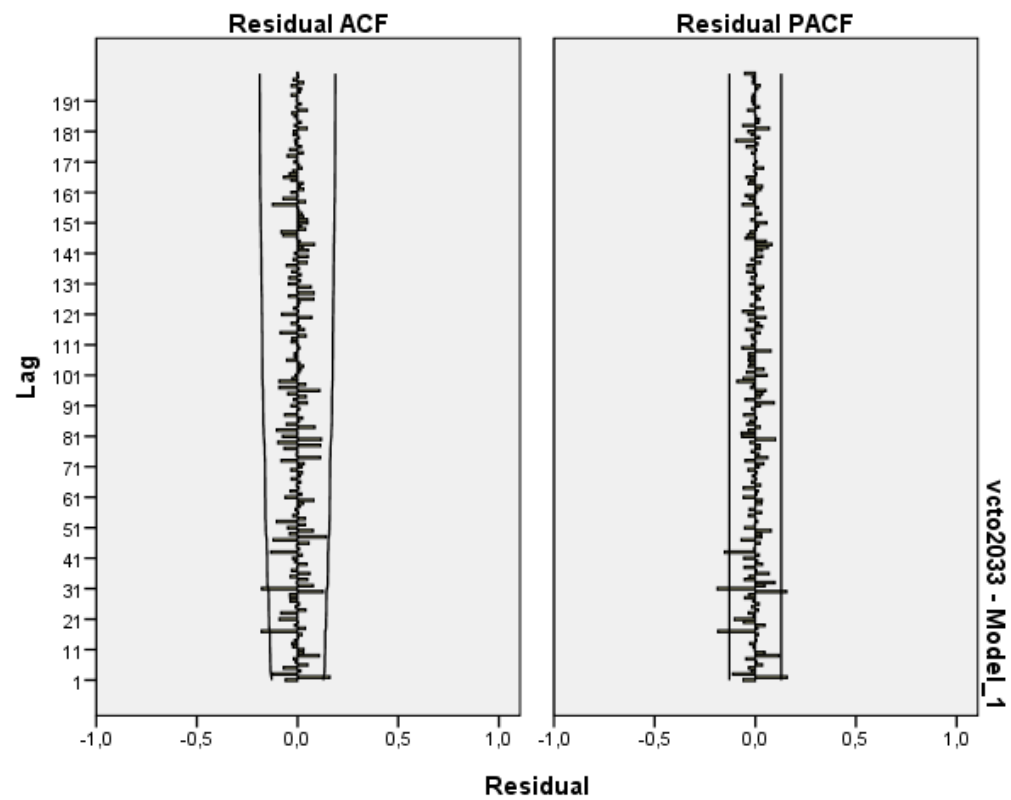

A dimensão da perda de retorno bruto sofrida pelos investidores estrangeiros que adquiriram a NTN-B ${ }_{2033}$ foi muito semelhante à sofrida pela NTN-B 2045 . A NTN-B 2033 sofreu uma tributação implícita, ao redor do dia da publicação da MP n ${ }^{\circ} 281 / 2006$, de cerca de $12 \%$. Uma vez mais, dada a perda acentuada, é provável que o investidor brasileiro fosse o investidor marginal da NTN-B 2033 quando da entrada dos estrangeiros ao tempo do início da isenção.

\subsubsection{NTN-B 2024}

Os retornos diários da NTN-B 2024 estão plotados no gráfico abaixo.

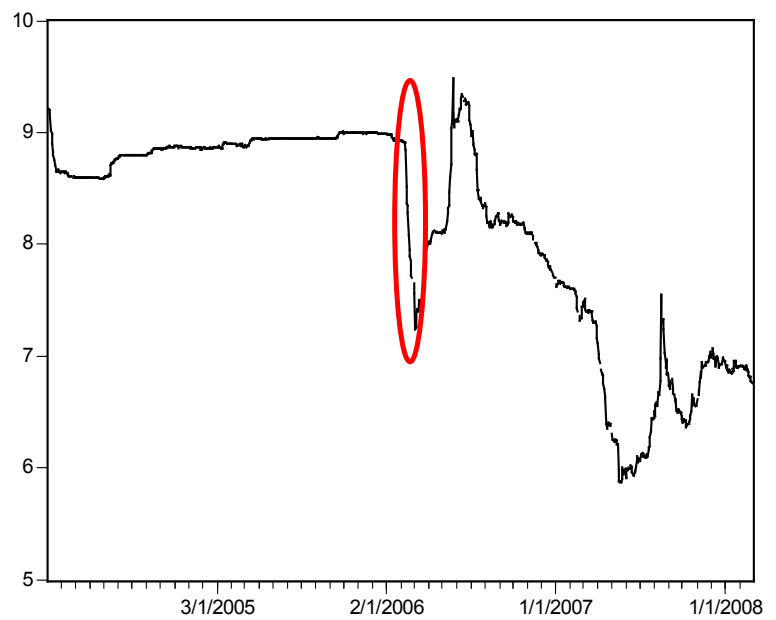

Gráfico 26 - retornos diários NTN-B ${ }_{2024}$ no período de 2/1/2004 a 28/2/2008 
Como ocorrido com as duas NTN-B anteriores, as primeiras diferenças, a partir do início de 2006, passaram a apresentar uma volatilidade mais acentuada, como demonstra o gráfico a seguir:

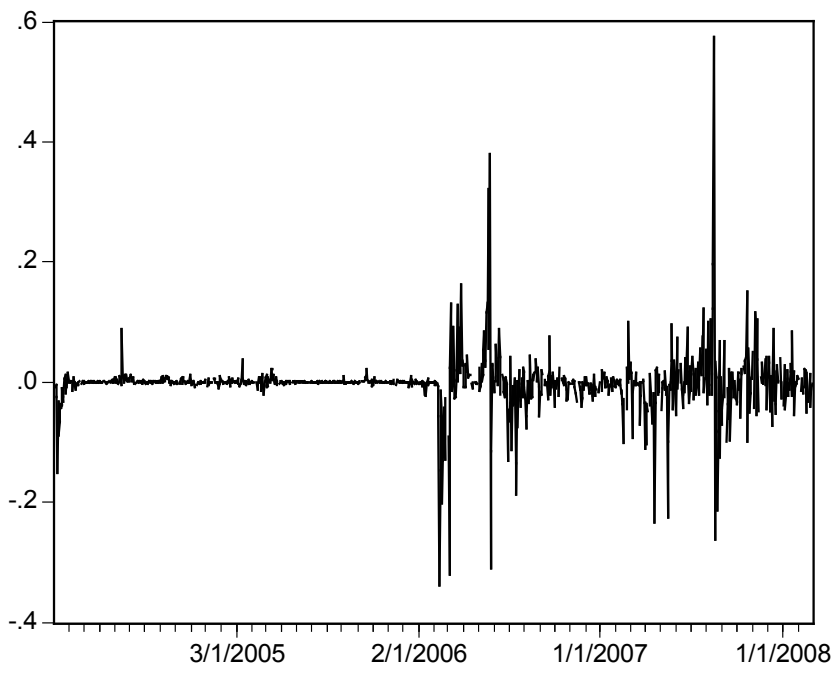

Gráfico 27 - primeiras diferenças NTN-B ${ }_{2024}(2 / 1 / 2004$ a 28/2/2008)

Além disso, a fim de se identificar o início da intervenção (assim como o término do período limpo) e a sua data final, apresenta-se o gráfico com os três primeiros meses e meio de 2006.

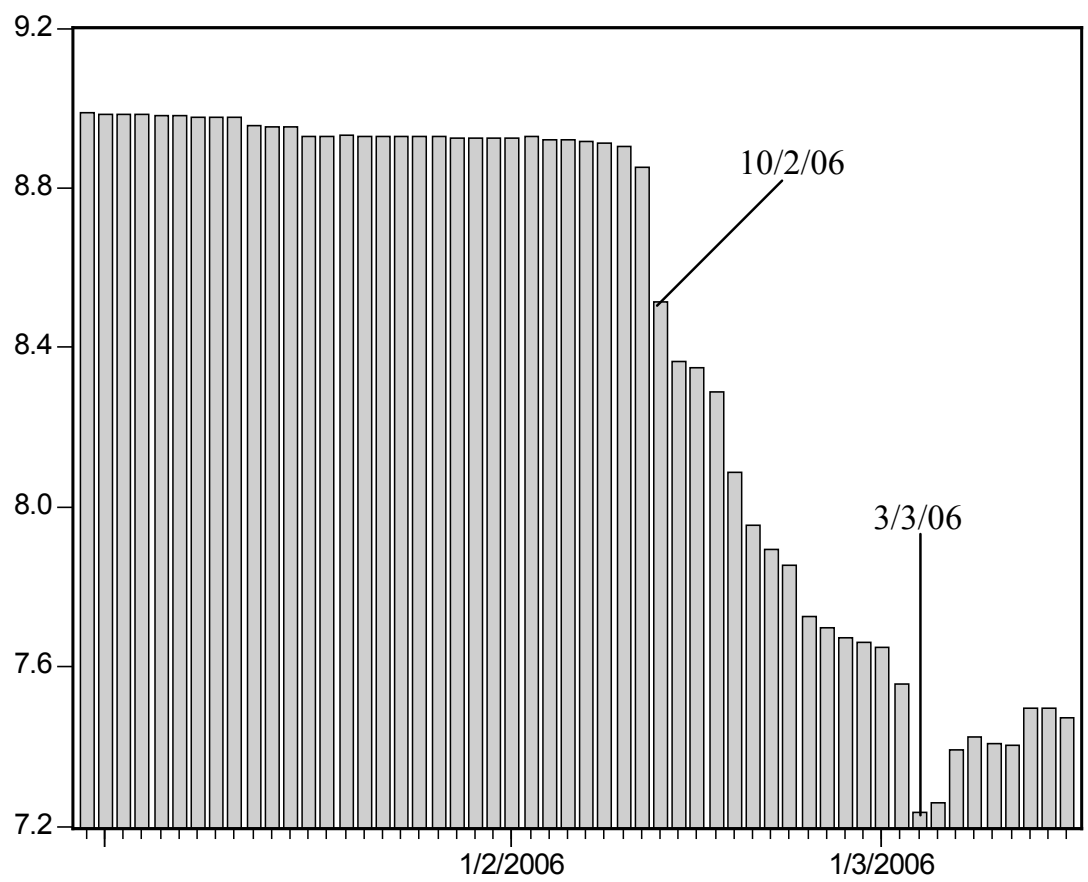

Gráfico 28 - retornos diários de NTN-B 2024 (2/1/2006 a 15/03/2006) 
As datas escolhidas de início e de final do evento são 10/2/2006 e 3/3/2006, respectivamente. A série de retornos "descontaminada" dos efeitos da intervenção irá de 3/1/2005 a 10/2/2006. O teste de Dickey e Pantula rejeitou a hipótese de existência de até três raízes unitárias..

Com auxílio do SPSS, o modelo que mais bem representou a série pré-intervenção foi um ARIMA $(0,1,3)$. A escolha do modelo de intervenção, novamente, recai sobre um evento de início abrupto e de duração permanente, como especificado pela Equação 16. A equação que engloba os períodos pré e pós-intervenção dos retornos da NTN-B 2024 é então dada por:

$$
Z_{t}=\omega S_{t}^{T}-\theta_{1} \varepsilon_{t-1}-\theta_{2} \varepsilon_{t-2}-\theta_{3} \varepsilon_{t-3}+\varepsilon_{t}
$$

Equação 20 - equação representativa dos retornos da NTN-B ${ }_{2024}$ no período de 3/1/2005 a 3/3/2006

Como esperado, os resultados quanto à existência da tributação implícita incidente sobre o retorno das $\mathrm{NTN}^{-B_{2024}}$ foram confirmados, à semelhança das NTN-B com vencimento em 2045 e 2033.

Tabela 17 - estatísticas e parâmetros do modelo estimado para a NTN-B $\mathbf{B}_{2024}$

\begin{tabular}{|ll|l|}
\hline & Model Description \\
\hline & & Model Type \\
\hline Model ID $\quad$ vcto2024 & Model_1 & ARIMA $(0,1,3)$ \\
\hline
\end{tabular}

Model Statistics

\begin{tabular}{|c|c|c|c|c|c|c|}
\hline \multirow[b]{2}{*}{ Model } & \multirow{2}{*}{$\begin{array}{l}\text { Number of } \\
\text { Predictors }\end{array}$} & $\begin{array}{l}\text { Model Fit } \\
\text { statistics }\end{array}$ & \multicolumn{3}{|c|}{ Ljung-Box Q(18) } & \multirow{2}{*}{$\begin{array}{c}\text { Number of } \\
\text { Outliers }\end{array}$} \\
\hline & & squared & Statistics & DF & Sig. & \\
\hline vcto2024-Model_1 & 1 & ,998 & 14,812 & 15 & ,465 & 38 \\
\hline
\end{tabular}

ARIMA Model Parameters

\begin{tabular}{|c|c|c|c|c|c|c|c|c|}
\hline & & & & & Estimate & SE & $\mathrm{t}$ & Sig. \\
\hline \multirow{6}{*}{$\begin{array}{l}\text { vcto2024- } \\
\text { Model_1 }\end{array}$} & vcto2024 & No Transformation & \multirow{2}{*}{\multicolumn{2}{|c|}{$\begin{array}{l}\text { Constant } \\
\text { Difference }\end{array}$}} & ,000 & ,000 & $-1,034$ & 302, \\
\hline & & & & & 1 & & & \\
\hline & & & & Lag 1 &,- 139 & ,065 & $-2,126$ & ,034 \\
\hline & & & \multirow[t]{2}{*}{ MA } & Lag 2 &,- 107 & ,067 & $-1,601$ & , 111 \\
\hline & & & & Lag 3 & , 150 & ,070 & 2,154 & ,032 \\
\hline & $S_{t}^{T}$ & No Transformation & \multicolumn{2}{|c|}{$(\omega)$} &,- 130 & ,001 & $-139,186$ & ,000 \\
\hline
\end{tabular}




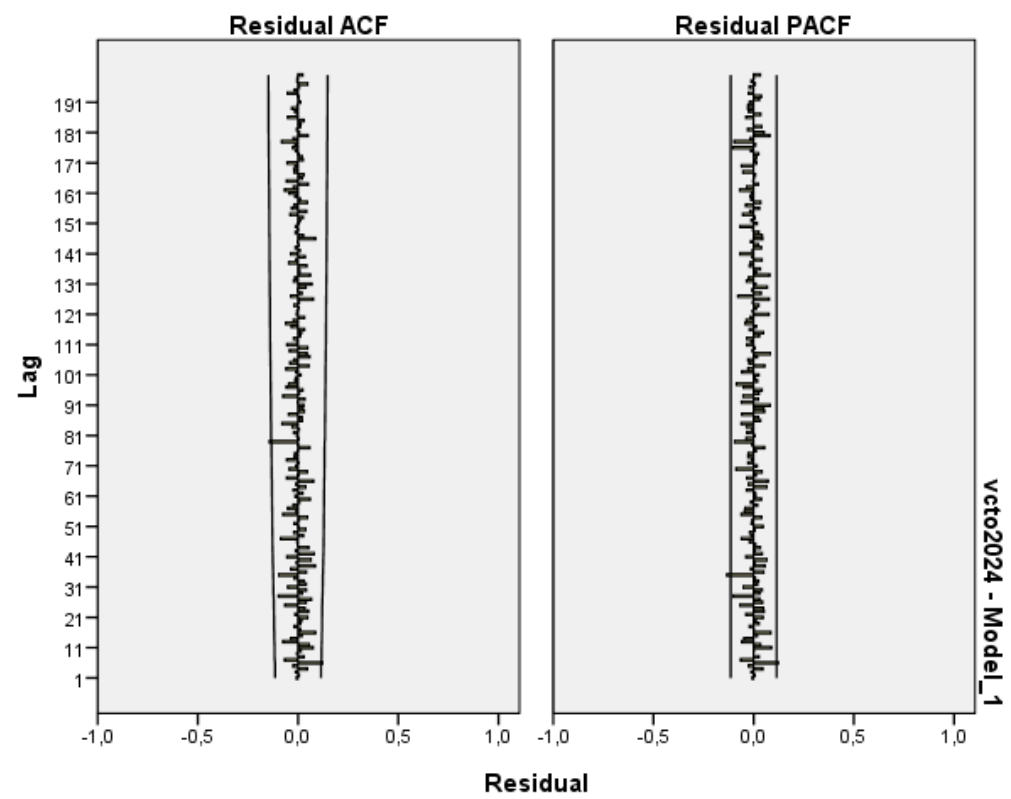

Os parâmetros do modelo $\operatorname{ARIMA}(0,1,3)$ são significativos a $5 \%$, com exceção do parâmetro MA(2). O adquirinte estrangeiro da NTN-B 2024 sofreu uma tributação implícita de cerca de 13\% no período de 10/2/2006 a 3/3/2006 nas negociações realizadas no mercado secundário.

\subsection{Outra vez a tributação implícita: o problema da liquidez}

Apesar de o foco da presente tese ser a comprovação dos efeitos sobre os retornos de títulos favorecidos pela isenção fiscal introduzida MP n 281/2006, houve pelo menos uma situação específica, ligada à falta de liquidez das NTN-B, que também provocou o surgimento de tributação implícita. Vê-se como oportuna a análise dessa nova situação (apresentada apenas para a NTN-B 2045 ) porque assim amplia-se o entendimento sobre um fenômeno que possui múltiplas facetas.

Após a entrada vigorosa dos investidores estrangeiros, com a conseqüente queda dos retornos das NTN-B, houve um momento em que os investidores começaram a exigir um retorno cada vez maior para adquiri-las. O Valor Econômico de 25/5/2006 noticiava: 
Atraídos ao país com a isenção de Imposto de Renda (IR), os investidores estrangeiros que aplicam em títulos públicos foram responsáveis ontem por um dos principais focos de pressão no mercado financeiro. Esses aplicadores procuravam se desfazer de títulos públicos de longo prazo, sobretudo Notas do Tesouro Nacional - Série B (NTNs-B), sem encontrar compradores para os papéis. Por fim, o Tesouro veio em socorro dos investidores, recomprando R\$ 1,753 bilhão em papéis e criando parâmetros de preço para um mercado que, sem referências, estava travado.

Em fevereiro, o governo editou uma medida provisória que isentou os investidores estrangeiros do pagamento de IR na aplicação em títulos negociados no mercado doméstico. Em três meses de vigência da regra, até abril, entraram liquidamente no país US\$ 6,573 bilhões. Na ocasião, 0 Tesouro argumentou que esses investidores têm apetite por papéis de longo prazo, o que ajudaria a alongar a dívida pública.

Nos últimos dias, com a aversão a risco provocada pela expectativa de maior aperto nos juros americanos, investidores estrangeiros começaram a resgatar títulos públicos e a remeter recursos para fora do país. A volatilidade tem sido particularmente alta porque os estrangeiros compraram sobretudo títulos de longo prazo, as NTNs-B, com vencimento até 2045, papéis com liquidez ainda reduzida e com mercado secundário incipiente.

A estratégia do Tesouro foi divulgada na mesma matéria:

Até a entrada dos investidores estrangeiros, essas NTNs-B eram vendidas principalmente para fundos de pensão nacionais, que têm como característica segurar os papéis até o vencimento, para honrar compromissos de longo prazo com seus associados. Junto com os estrangeiros, entraram também investidores nacionais mais agressivos, interessados em lucrar com a rápida valorização do papel, provocada pelo súbito aumento de demanda.

$\mathrm{O}$ jogo virou com a turbulência recente no mercado financeiro. A reação do Tesouro veio no início da tarde de ontem, com a realização de um leilão de NTN-B, com vários prazos, tanto para recomprar os papéis quanto para vender. E foi marcado um leilão nos mesmos moldes para hoje. "O principal interesse do Tesouro é que esses leilões forneçam parâmetros de preço para o mercado", disse o secretário-adjunto do Tesouro, Paulo Valle. "O mercado fica meio travado em momentos de estresse. O leilão mostra que, para determinado preço, aparecem compradores."

$\mathrm{O}$ Tesouro, de um lado, recomprou $\mathrm{R} \$ 1,753$ bilhão, fornecendo liquidez para o mercado. De outro, vendeu R\$ 687 milhões, mostrando que, aos preços que chegaram, há investidores dispostos a comprar NTNs-B. O papel com vencimento em 2045 paga o IPCA mais $9 \%$, bem acima da meta atuarial de vários fundos de pensão, de inflação mais $6 \%$.

A matéria do Valor Econômico pode ser confirmada graficamente. Abaixo, são apresentados dois gráficos que demonstram o efeito da falta de liquidez das NTN-B e a resposta do Tesouro para solucionar esse problema. Para que a situção possa ser visualizada com mais clareza, mostram-se no primeiro gráfico os retornos da NTN-B ${ }_{2045}$ de $3 / 3 / 2006$, considerada a data final do evento diretamente ligado à isenção da MP, até o auge da ajuda governamental (o leilão do dia 24/5/2006); no segundo gráfico, apresentam-se os retornos após o leilão. 


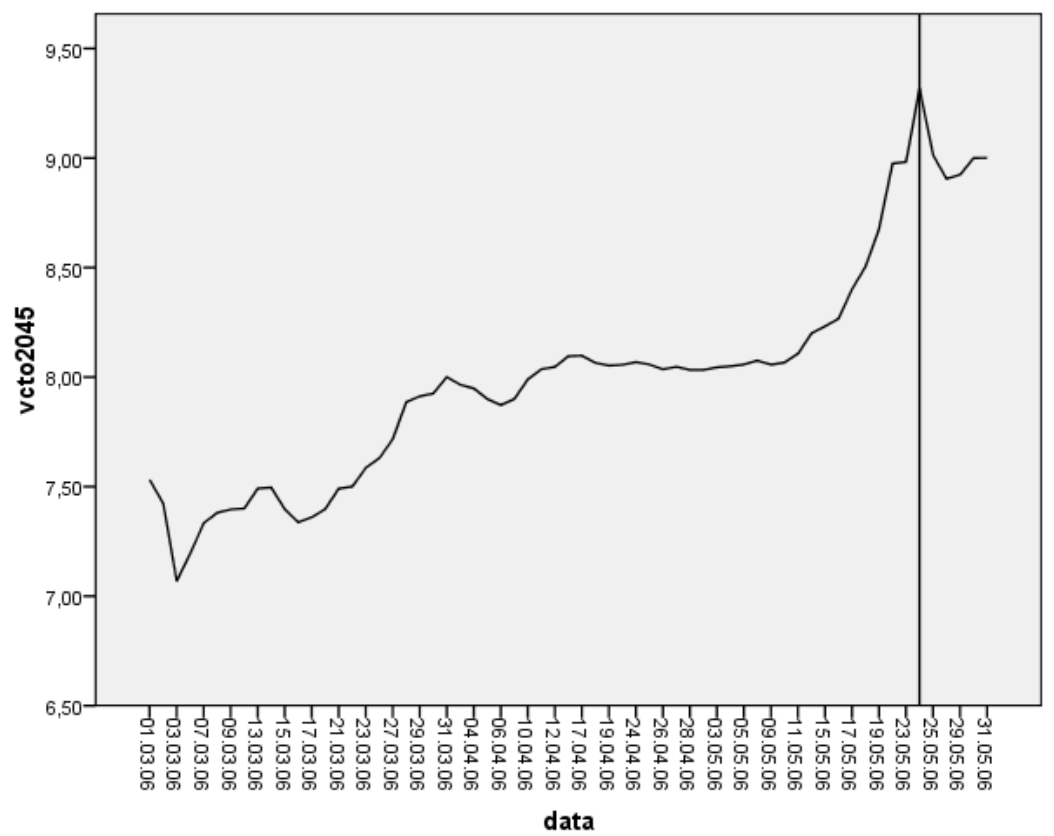

Gráfico 29 - retornos NTN-B ${ }_{2045}$ do final da intervenção causada pela MP n$^{0}$ 281/2006 até o leilão empreendido pelo governo para dar liquidez às NTN-B

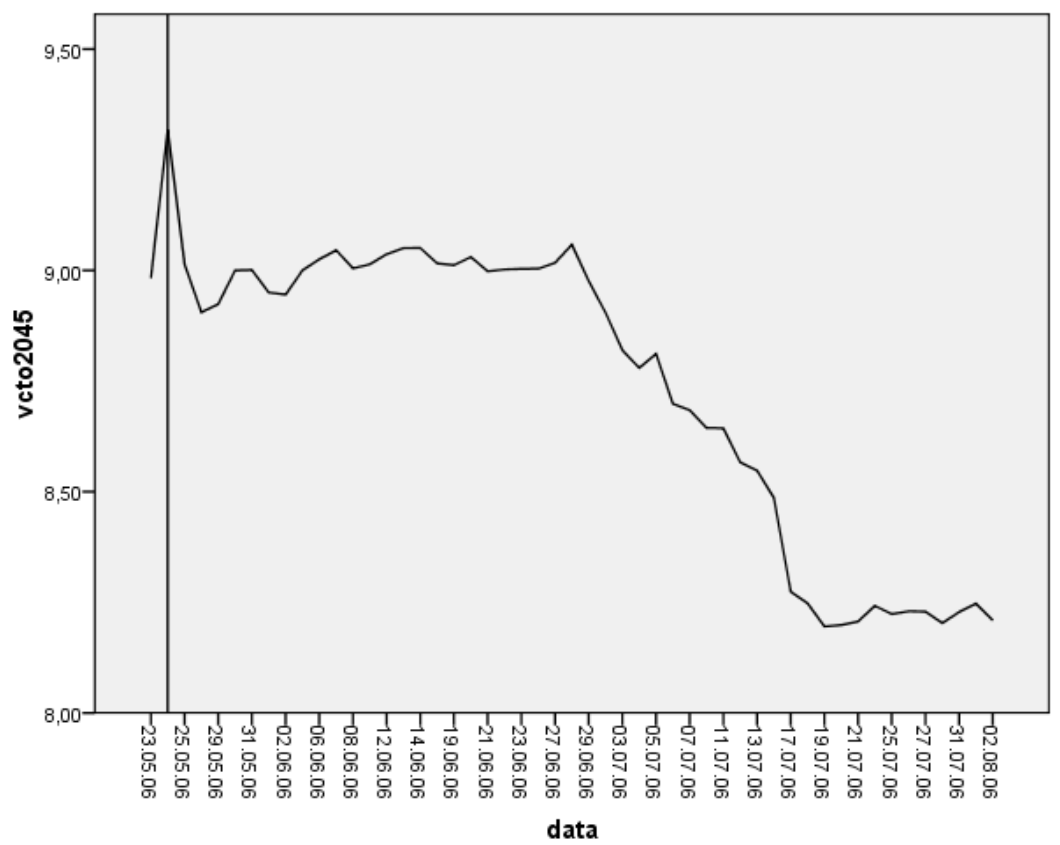

Gráfico 30 - retornos NTN-B 2045 após leilão realizado em 24/5/2006

O Gráfico 29 mostra que o retorno mínimo admitido pelo investidor estrangeiro, pelo menos no período próximo à publicação da $\mathrm{MP} \mathrm{n}^{\mathrm{o}}$ 281/06, ocorreu em 3/3/2006. Depois disso, o investidor passou a exigir um retorno cada vez maior para carregar a NTN-B 2045 , até o ponto de o governo se sentir pressionado o suficiente para aceitar as condições impostas pelo mercado desses títulos. 
A linha vertical nos dois gráficos indica o retorno máximo "pago" pelo governo, a saber, no leilão realizado em 24/5/06. Do ponto de vista da tributação implícita, trata-se de situação diversa àquela estudada anteriormente: não mais se está falando em perda de retorno (pelo investidor estrangeiro) causada por aumento de demanda decorrente de uma isenção tributária; agora, trata-se de um aumento de retorno exigido pelo estrangeiro que desejava se desfazer do papel. Se antes o investidor estrangeiro "pagou" uma tributação implícita (para o investidor nacional) ao aceitar um retorno pré-imposto menor, nesse segundo momento esse mesmo investidor estrangeiro "recebeu" um tributo implícito ("pago" pelo governo) por meio de um retorno maior.

Repita-se, portanto, que a expressão "tributação implícita" não tem a conotação de um tributo explícito, que é pago por contribuintes e recebido por entes governamentais. Nos leilões realizados pelo Tesouro, o governo foi quem pagou a tributação implícita ao investidor estrangeiro. Nesse jogo de mercado, o governo parece ter agido coerentemente com seus planos, como demonstra a queda de retorno que se seguiu ao leilão.

Observe-se a importância da figura do investidor marginal. Antes da isenção, o investidor marginal da NTN-B era o investidor brasileiro; foi ele que, ao sabor das condições, sentiu-se estimulado a vendê-la quando houve interessados que, beneficiados por uma isenção, se mostraram dispostos a pagar um preço maior pelo título favorecido. Num segundo momento, o investidor estrangeiro, apesar de possuir uma parcela considerável das NTN-B, não dispunha do poder para vendê-las, não havia interessados em adquiri-las: o investidor estrangeiro era então um investidor inframarginal. O que o Tesouro fez foi dar a condição de investidor marginal ao estrangeiro; ao "aceitar" o preço de venda cobrado pelos estrangeiros, o governo, dando liquidez à NTN-B, deu-lhes a condição de price maker, própria do investidor marginal.

A tributação implícita surge quando, sob a condição de equilíbrio de mercado, um título favorecido tributariamente tem seu retorno pré-imposto reduzido em comparação com o retorno de títulos de mesmo risco e que não gozem do favor tributário. É interessante analisar o que ocorreu após aquele primeiro momento a partir do qual a isenção passou a valer. $\mathrm{O}$ benefício introduzido pela MP n ${ }^{\circ}$ 281/06 favoreceu títulos públicos brasileiros adquiridos por estrangeiros. Como aqui comprovado, a NTN-B, título escolhido pelo investidor estrangeiro, 
sofreu uma redução significativa do seu retorno. Como se pode, no momento seguinte, associar um problema de liquidez ao surgimento da tributação implícita?

Segundo se noticiou, um dos fatores que influenciaram a saída dos estrangeiros foi o aperto dos juros americanos. A redução para zero da alíquota de imposto de renda incidente sobre rendimentos produzidos por títulos públicos, antes favorável ao investidor estrangeiro, passou a ser-lhe desfavorável: o benefício tributário da isenção ficou menor que o custo de oportunidade $^{27}$ do investidor estrangeiro. O favor tributário transformou-se em "desfavor tributário", pois, sem liquidez para aproveitar os juros americanos, carregar as NTN-B ficou desvantajoso. É como se, a partir do aumento dos juros americanos, o benefício tributário passasse de positivo a negativo. Assim como um ativo favoravelmente tributado possui um retorno bruto menor que o retorno de ativos sem favores tributários, um ativo que passe a ser trbutado desfavoravelmente terá seu retorno pré-imposto aumentado em comparação com outros ativos sem desfavorecimento tributário. Em outras palavras, o investidor estrangeiro "recebeu" um tributo implícito positivo cedido pelo governo. Por outro lado, o governo brasileiro aceitou "pagar" o tributo implícito naquele momento para ter o investidor estrangeiro de volta em momento posterior, quando o custo de oportunidade propiciado pelo aumento dos juros americanos se tornasse menor que o benefício tributário da MP $\mathrm{n}^{\mathrm{o}}$ $281 / 2006$.

Retome-se o modelo estimado para os retornos da NTN-B ${ }_{2045}$ dado pela Equação 18. Por meio desse modelo, pode-se agora estimar qual foi a tributação implícita recebida pela estrangeiro quando o governo resolveu ceder às pressões para aumentar a liquidez das NTN-B. Pelo Gráfico 29, admita-se que, a partir de 18/5/2006, houve um aumento mais pronunciado no retorno exigido pelo investidor estrangeiro, tendo como clímax o retorno obtido no dia 24/5/2006, data de realização do primeiro leilão organizado pelo Tesouro.

O modelo estimado pela Equação 18 incluía tão-somente os retornos até o dia 3/3/2006, data em que se chegou ao retorno mínimo aceito pelo investidor estrangeiro em resposta direta à isenção da MP n 281/2006. Esse mesmo modelo pode ser ampliado para estimar a tributação implícita recebida pelos estrangeiros à época do leilão promovido pelo governo em 24/5/2006.

\footnotetext{
${ }^{27}$ Para um aprofundamento sobre custo de oportunidade, consultar a dissertação de mestrado de Auster Moreira Nascimento, "Uma Contribuição para o Estudo dos Custos de Oportunidade”, FEA-USP, 1998.
} 
O modelo geral dos retornos da NTN-B 2045 , dado pela Equação 17, de forma que ele passe a englobar tanto o primeiro evento (MP $\mathrm{n}^{\mathrm{o}}$ 281/06) quanto o segundo evento (liquidez) passa a ter a seguinte formulação:

$$
Z_{t}=\omega_{1} S_{1 t}^{T}+\frac{\omega_{2} B}{(1-\delta B)} P_{t}^{T}+\varepsilon_{t}
$$

Equação 21 - equação geral dos retornos da NTN-B, incluídas as duas intervenções

A Equação 21 inclui os dois eventos. $\mathrm{S}_{1}$ é o evento, já testado, da perda acentuada de retorno em virtude da entrada em vigor da isenção da MP $n^{\circ}$ 281/06, cujo período teve a duração estipulada do dia 10/2/2006 a 3/3/2006; a segunda parte da Equação 21 simboliza matematicamente o período em que os investidores passaram a exigir de forma mais acentuada um retorno maior, cujo início foi arbitrariamente escolhido como sendo 18/5/2006 e o término coincidindo com o dia do leilão, 24/5/2006. Cabe observar que o segundo evento, diferentemente do primeiro, teve seu início ocorrido abruptamente, mas seus efeitos foram temporários, como mostra o Gráfico 30. Por isso, sua representação matemática é dada pela expressão $\frac{\omega_{2} B}{(1-\delta B)} P_{t}^{T}$, retirada de Vandaele (op. cit., 1983, p. 337), que indicou essa expressão como simbólica de um evento com início abrupto e de duração temporária. A variável $P_{t}^{T}$ é do tipo pulse, como explicada na seção 4.2.4. O formato da curva do evento é obtido pela relação entre os polinômios $\omega$ e $\delta$.

O relatório de saída do SPSS referente ao modelo com os dois eventos está na seqüência. Para fins de visualização dos resultados, a Equação 21 passa a ser representada por:

$$
Z_{t}=\omega S_{1 t}^{T}+\psi P_{t}^{T}+\varepsilon_{t}
$$

Equação 22 - notação simplificada da Equação 21

Tabela 18 - estimativas do modelo que inclui os dois eventos: MP n²81/06 e liquidez

Model Description

\begin{tabular}{|ll|c|}
\hline & & Model Type \\
\hline Model ID vcto2045 $\quad$ Model_1 & ARIMA $(1,1,1)$ \\
\hline
\end{tabular}


Model Statistics

\begin{tabular}{|l|c|c|c|c|c|c|}
\hline \multirow{2}{*}{} & \multirow{2}{*}{ Model } & \multicolumn{2}{c|}{$\begin{array}{c}\text { Model Fit } \\
\text { statistics }\end{array}$} & \multicolumn{2}{|c|}{ Ljung-Box Q(18) } & \\
\cline { 3 - 6 } & \multirow{2}{*}{$\begin{array}{c}\text { Number of } \\
\text { Predictors }\end{array}$} & $\begin{array}{c}\text { Stationary R- } \\
\text { squared }\end{array}$ & Statistics & DF & Sig. & $\begin{array}{c}\text { Number of } \\
\text { Outliers }\end{array}$ \\
\hline vcto2045-Model_1 & 2 &, 995 & 9,680 & 16 &, 883 & 57 \\
\hline
\end{tabular}

ARIMA Model Parameters

\begin{tabular}{|c|c|c|c|c|c|c|c|c|}
\hline & & & & & Estimate & SE & $\mathrm{t}$ & Sig. \\
\hline \multirow{6}{*}{$\begin{array}{l}\text { vcto2045- } \\
\text { Model_1 }\end{array}$} & vcto 2045 & No Transformation & \multicolumn{2}{|c|}{ Constant } &, 001 & ,001 & 1,087 & ,278 \\
\hline & & & \multirow{2}{*}{\multicolumn{2}{|c|}{$\begin{array}{l}\text { AR Lag } 1 \\
\text { Difference }\end{array}$}} & ,919 &, 040 & 23,197 &, 000 \\
\hline & & & & & 1 & & & \\
\hline & & & MA & $\operatorname{Lag} 1$ & ,618 & ,080 & 7,683 &, 000 \\
\hline & $S_{1_{t}}^{T}$ & No Transformation & \multicolumn{2}{|c|}{$\omega$} &,- 111 & ,003 & $-41,237$ &, 000 \\
\hline & $P_{t}^{T}$ & No Transformation & \multicolumn{2}{|c|}{$\Psi$} & ,209 & ,004 & 55,582 &, 000 \\
\hline
\end{tabular}

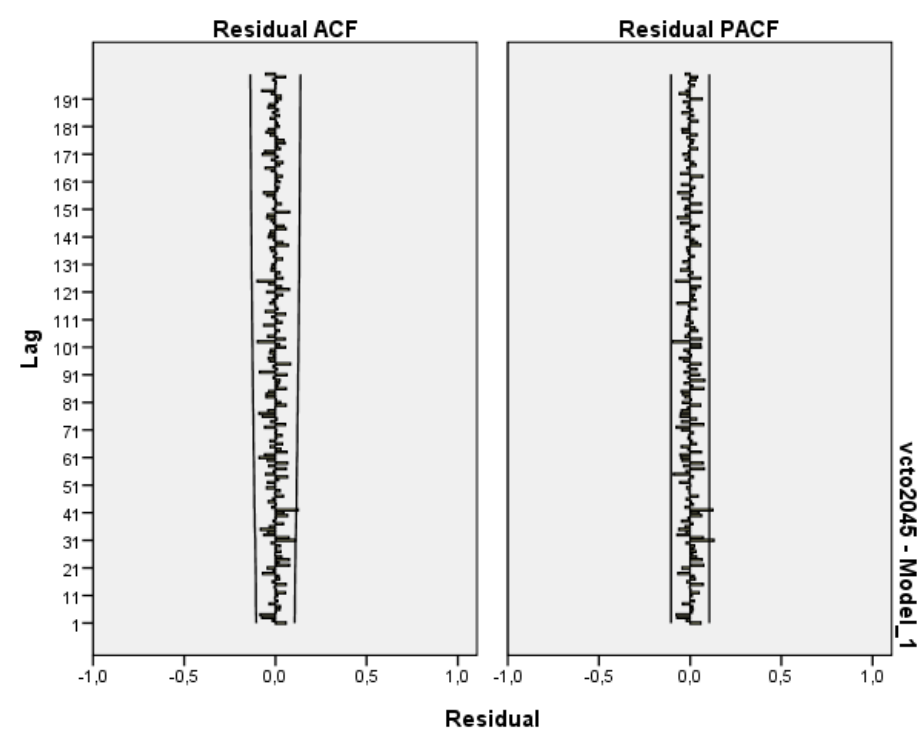

As estimativas dos dois parâmetros são significativas estatisticamente. Se, no momento em que entrou comprando a NTN-B 2045 , o investidor estrangeiro "pagou" um tributo implícito de $11 \%$, no período próximo ao leilão ele recebeu de volta $21 \%$ de tributo implícito ${ }^{28}$.

\footnotetext{
${ }^{28}$ Para recuperar a perda de retorno sofrida quando entraram, bastaria aos investidores estrangeiros receberem um tributo implícito de aproximadamente $12,4 \%$ no momento em que saíram.
} 


\section{CONCLUSÃO}

$\mathrm{O}$ intuito desta pesquisa foi apresentar os conceitos correlatos à tributação implícita e comprová-los empiricamente. Apresentados os fundamentos econômicos e os conceitos correlatos ao tema, o propósito da parte empírica foi comparar os retornos de ativos antes e depois de uma alteração legislativa que beneficiou, por escolha do investidor, um ativo em particular, semelhantemente a Guenther (1994) e Erickson e Maydew (1998). Ao se comparar retornos de um mesmo título ao longo do tempo, reduz-se a dificuldade de se isolar os efeitos tributários dos efeitos cross-sectional que podem surgir quando comparados os retornos de ativos tributados diferentemente e com riscos diversos ${ }^{29}$.

O evento utilizado foi a MP $\mathrm{n}^{\mathrm{o}} 281$, publicada em 16 de fevereiro de 2006, que isentou o investidor estrangeiro do imposto de renda incidente sobre o rendimento de títulos públicos adquiridos após a sua publicação. A teoria econômica prediz que, em condições de equilíbrio de mercado, o tratamento tributário favorável a um ativo conduzirá a uma redução do retorno pré-imposto comparativamente ao retorno de outro ativo de mesmo risco que não goze de benefício tributário. O investidor estrangeiro aplicou majoritariamente na NTN-B, que antes da isenção estava, quase na sua totalidade, nas mãos do investidor brasileiro. Assim, pôde-se verificar o que ocorreu com o retorno da NTN-B depois do benefício fiscal comparativamente ao retorno anterior ao favor tributário, haja vista que, nas mãos do investidor estrangeiro, a NTN-B passou a ser um ativo favoravelmente tributado quando comparada a ela própria antes da MP (sem favorecimento).

O evento "MP $n^{\circ} 281$ " foi uma escolha particulamente feliz porque se puderam visualizar as várias faces da tributação implícita. Num primeiro momento, nos dias ao redor da pubilicação da MP, comprovou-se uma perda de retorno significativa para todas as três séries de NTN-B

\footnotetext{
${ }^{29}$ Futuras pesquisas podem utilizar outras técnicas econométricas que envolvam séries de tempo e que aceitem alterações da variância ao longo do tempo. Modelos ARCH (Engle, 1982) e GARCH (Bollerslev, 1986) são dois exemplos. O modelo ARCH foi projetado para capturar o efeito das mudanças da variância ao longo do tempo, de forma a especificá-la como uma função linear do termo aleatório passado. Assim, grandes variações passadas são modeladas para incrementar a variabilidade corrente. O modelo GARCH estende o modelo ARCH para permitir que as variâncias corrente e passadas do termo aleatório afetem o modelo gerador da amostra. O consagrado modelo de precificação de opções de Black\&Scholes, por exemplo, tem como premissa que os retornos do ativo-objeto são normalmente distribuídos e possuem volatilidade constante no tempo. Vários estudos, contudo, dão conta de que os retornos das ações possuem distribuição com caudas largas e variância inconstante ao longo do tempo, o que pode ser acomodado com o uso de modelos ARCH/GARCH.
} 
examinadas. Nesse momento, ficou clara a condição de investidor marginal exercida pelo investidor nacional. Corroborando o comportamente racional que geralmente pauta as ações dos participantes do mercado, o investidor brasileiro se desfez das NTN-B porque havia interessados (investidor estrangeiro) em pagar um sobrepreço por elas, aproveitando uma janela de oportunidade para adquirir outros ativos de mesma remuneração a preços inferiores. O nacional "recebeu" o tributo implícito "pago" pelo investidor estrangeiro.

Passado esse momento incial, o investidor estrangeiro, por um aumento dos juros nos EUA, quis se desfazer das NTN-B recém-adquiridas. Como o investidor brasileiro provavelmente possuía investimentos que lhe propiciavam retornos iguais ou superiores a preços mais atrativos, os retornos exigidos para aceitar as NTN-B foram cada vez maiores. O investidor estrangeiro estava então revestido da condição de investidor inframarginal: ele compunha a clientela tributária das NTN-B. Sem ter como vender os papéis, o investidor estrangeiro pressionou o governo, que comprou os títulos, do contrário dificilmente o estrangeiro retornaria aos papéis. À luz dos conceitos correlatos à tributação implícita, pode-se interpretar que o governo, ao fornecer liquidez ao título, promoveu o investidor estrangeiro à condição de investidor marginal. Agora, foi o investidor estrangeiro que "recebeu" o tributo implícito "pago" pelo governo.

A MP nº 281 permitiu que se explorassem os conceitos ligados ao tema "tributação implícita". São conceitos importantes e que podem ser utilizados por empresas, investidores e formuladores de políticas públicas. No entanto, não foram poucas as críticas a uma desoneração tributária do investidor estrangeiro. A Andima, em estudo pré-MP, apresentou alguns contra-argumentos comumente citados pelos céticos à proposta de desoneração do ingresso do capital estrangeiro no país. Aparentemente de forma acertada, a Andima procurou rebater os argumentos dos descrentes: "Muitos dos pontos levantados - que a princípio, de fato, soam razoáveis - dissolvem-se após uma análise um pouco mais profunda" (ANDIMA, 2005, p. 31).

Entre os pontos contrários utilizados por vários analistas contrários à desoneração tributária de estrangeiros, havia o de que a desoneração geraria perda de arrecadação, "exportaria" a tributação e estimularia a evasão fiscal por parte dos residentes. Segue-se a resposta da Andima (2005, p. 34): 
Finalmente, cabe analisar a questão de que a desoneração dos rendimentos desse investidor tenderia a facilitar práticas de evasão e de sonegação fiscal, por parte dos residentes. A idéia é a de que estes usariam expedientes de planejamento tributário para aplicar seus recursos como se estrangeiros fossem, beneficiando-se, assim, da isenção fiscal concedida àqueles. Mais uma vez, o argumento é falho, e parece não levar em conta o arcabouço legal brasileiro relativo à tributação dos rendimentos auferidos no exterior pelos residentes no Brasil.

No caso do investidor pessoa física, por exemplo, os ganhos reais em moeda estrangeira, tais como juros, são tributados no momento em que ocorrem - mesmo antes da internalização -, por meio do chamado carnê-leão. Quando do retorno dos recursos ao Brasil, todo o ganho em moeda brasileira, incluindo os decorrentes de variação cambial, deve ser oferecido à tributação.

A forma legal de que o contribuinte dispõe para minimizar o peso tributário sobre os rendimentos de suas aplicações no exterior é a constituição de empresas offshore, na maior parte das vezes em paraísos fiscais. Aqui, porém, não se trata de sonegação ou evasão, mas simplesmente de diferimento do pagamento do tributo. A legislação atual é bastante eficiente para coibir a sonegação fiscal por esse canal. No fechamento de câmbio, para fazer a remessa dos recursos ao exterior, a qualquer título, é necessária a identificação completa do remetente, bem como sua inscrição no $\mathrm{CPF}$ ou no $\mathrm{CNPJ}$, ficando o contribuinte sujeito à comprovação da origem dos recursos. Além disso, as pessoas físicas ou jurídicas, residentes ou com sede no país, detentoras de valores de qualquer natureza, de bens e direitos, fora do território nacional, em montante igual ou superior a US\$ 100 mil, são obrigadas a prestar essa informação ao Banco Central, mediante o preenchimento da Declaração Eletrônica de Capitais Brasileiros no Exterior - CBE, nos termos da Circular 3.278, de 23 de fevereiro de 2005. Assim, os residentes que possuírem quotas de empresas offshore têm seus nomes vinculados às mesmas por vários canais, sendo também obrigados a informar tais valores na Declaração de Bens e Direitos constante da Declaração Anual de Rendimentos entregue à Secretaria da Receita Federal. Práticas em desacordo com as mencionadas normas caracterizariam atos ilícitos e em nada seriam facilitadas ou estimuladas pela desoneração dos rendimentos obtidos pelo investidor estrangeiro na aquisição de papéis da dívida pública no mercado doméstico.

Adicionalmente, a exemplo do que ocorre em outros países, a legislação poderia obrigar a instituição financeira que faz a intermediação a identificar, sob sua responsabilidade, o beneficiário final da operação, destacando se é ou não residente no Brasil. Assim, a pessoa física ou jurídica com domicílio fiscal no Brasil que comprasse títulos da dívida pública por intermédio de uma offshore da qual seja sócia teria que se identificar como residente junto à instituição financeira e não faria jus à isenção fiscal. No jargão do mercado financeiro internacional, tal medida é conhecida como beneficial owner e tem-se mostrado eficaz para coibir a prática de residentes usarem indevidamente o benefício fiscal concedido aos estrangeiros12. Como em qualquer norma legal, um sistema firme de fiscalização e punições severas aos infratores deveria ser estabelecido (enforcement). No sistema proposto, a fiscalização seria bastante facilitada, dado que se concentraria nas instituições financeiras, a quem seria atribuída a obrigatoriedade legal de zelar pela correta identificação do domicílio fiscal de seus clientes.

Nesse mesmo estudo, fez-se uma simulação de quanto baixariam os juros em respota a uma redução da alíquota de imposto somente para os investidores externos. Essa simulação, em última instância, reflete o mecanismo econômico pelo qual opera a tributação implícita. Apesar de utilizar argumentos válidos, a resposta da Andima aos céticos não fazia qualquer menção à tributação implícita sofrida pelo investidor estrangeiro quando da sua entrada para adquirir os títulos beneficiados. Talvez a menção ao mecanismo de perda de retorno dos ativos beneficiados fosse um argumento que reforçasse a linha pró-isenção. Afinal, a tributação implícita sofrida pelo investidor estrangeiro (ou que por estrangeiro se pretendeu passar), que variou de $11 \%$ a $13 \%$ dependendo do vencimento da NTN-B em que ele aplicou, 
aproximava-se bastante da tributação na fonte (explícita) sofrida por não-estrangeiros ${ }^{30}$. É provável que os custos de transação de uma operação de planejamento pouco ortodoxa, como as exemplificadas pela Andima, somados à tributação implícita, ficassem bem acima do imposto explícito exigido dos nacionais, o que, por si só, poderia ser uma razão considerável para inibir investidores nacionais tentados a se travestir de estrangeiros.

Os resultados obtidos contribuem para a pequisa tributária que procura investigar empiricamente a influência dos tributos sobre o preço de ativos. Mais especificamente, este estudo fornece informações teóricas e empíricas de como mudanças na incidência tributária influenciam o retorno pré-imposto de ativos, dando margem ao aparecimento da tributação implícita. Os resultados contribuem também, de um lado, para investidores que necessitam a todo instante de informações precisas sobre o retorno de seus investimentos e nas variadas formas de obter maximização dos valores aplicados; por outro lado, podem contribuir para empresas que procurem por maximização da sua política de dividendos, na medida em que podem aplicar a teoria de clientela tributária à sua política de distribuição de lucros. Por fim, e não menos importante, os resultados contribuem para que formuladores de políticas macroeconômicas adquiram conhecimentos adicionais acerca de como mudanças tributárias podem auxiliar na melhoria dos fundamentos da economia com um todo ou especificamente quando levados em conta na política de desoneração aplicada a determinados ativos.

\footnotetext{
${ }^{30}$ A partir de 2004, a NTN-B passou a ser tributada (Lei n ${ }^{\circ} 11.033$, de $21 / 12 / 2004$ ) em 22,5\% no primeiro pagamento de juros, em $20 \%$ no segundo, $17,5 \%$ no terceiro e em $15 \%$ para todos os demais pagamentos.
} 


\section{REFERÊNCIAS}

ASSOCIAÇÃO NACIONAL DAS INSTITUIÇÕES DO MERCADO FINANCEIRO ANDIMA. Relatório econômico: participação do investidor estrangeiro na dívida pública. Rio de Janeiro, 2005.

ASSOCIAÇÃO NACIONAL DAS INSTITUIÇÕES DO MERCADO FINANCEIRO ANDIMA. Brasil para investidores estrangeiros. Rio de Janeiro: ANDIMA, 2007.

ASSOCIAÇÃO NACIONAL DAS INSTITUIÇÕES DO MERCADO FINANCEIRO ANDIMA. Código Operacional do Mercado. Julho/2008.

Ataque especulativo contra o real eleva dólar a R\$ 2,40. Valor Econômico. 25/5/2006.

AYERS, Benjamin C.; CLOYD C. Bryan; ROBINSON, John R. The effect of shareholderlevel dividend taxes on stock prices: evidence from the Reconcialion Act of 1993. The Accounting Review; Oct 2002; 77, 4; ABI/INFORM Global, p. 933-947.

AYERS, Benjamin C; LEFANOWICZ, Craig E; ROBINSON, John R. The effects of goodwill tax deductions on the market for corporate acquisitions. The Journal of the American Taxation Association; 2000; 22, ABI/INFORM Global, p. 34-50.

BANCO CENTRAL DO BRASIL. Risco-país: série perguntas mais freqüentes. Atualizado em agosto de 2006, com dados até junho/julho de 2006.

BLACK, Fisher; SCHOLES, Myron S. The effects of dividend yield and dividend policy on common stock prices and returns. Journal of Financial Economics. Volume 1, Issue 1, May 1974, Pages 1-22.

BOLLERSLEV, T. Generalized autoregressive conditional heteroskedasticity. Journal of Econometrics, v. 31, p. 307-327, 1986.

BOX, G. E. P.; JENKINS, G. M. Time series analysis: forecasting and control. San Francisco, Holden-Day, 1976.

CALLIHAN, Debra S; WHITE, Richard A. An application of the Scholes and Wolfson model to examine the relation between implicit and explicit taxes and firm market structure. The Journal of the American Taxation Association. Spring 1999; 21, 1; ABI/INFORM Global p. 1-19.

DHALIWAL, Dan S. et al. A test of the theory of tax clienteles for dividend policies. National Tax Journal. v.52, n. 2, p. 179-195, Jun 1999. 
DHALIWAL, Dan S.; LI, Oliver Zhen; TREZEVANT, Robert. Is a dividend tax penalty incorporated into the return on a firm's common stock?. Journal of Accounting and Economics, Vol. 35, No. 2, p. 155-178, April 2003.

DICKEY, D. A.; PANTULA, S. Determining of the estimators for autoregressive process. Journal of Business and Economics Statistics, v. 15, p. 455-461, 1987.

ENDERS, W. Applied econometric time series. New York: John Wiley \& Sons, Inc., 1995.

ENGLE, R. F. Autoregressive conditional heteroskedasticity with estimates of the variance of United Kingdom inflation. Econometrica v. 50, p. 987-1008, 1982.

ERICKSON, Merle M.; MAYDEW, Edward L. Implicit taxes in high dividend yield stocks. The Accounting Review. Oct 1998; 73, 4; ABI/INFORM Global, p. 435-458.

ERICKSON, Merle Matthew. The effect os taxes on the structure of corporate acquisitions. Arizona, 1996. Tese (Doutorado em Administração). The University of Arizona.

ERICKSON, Merle Matthew. The effect os taxes on the structure of corporate acquisitions. Journal of Accounting Research (2), p. 279-298, 1998.

FAMA, Eugene F.; FRENCH, Kenneth R. Taxes, Financing Decisions, and Firm Value.The Journal of Finance, v. 53, Issue 3, month 6, p. 819-843, 1998.

GARCIA, Márcio G. P.; DIDIER, Tatiana. Taxa de juros, risco cambial e risco Brasil. Pontifícia Universidade Católica - PUC, Rio de Janeiro, 2001.

GRAHAM, John R. Debt and the marginal tax rate. Journal of Financial Economics. Amsterdam: May 1996. Vol. 41, Iss. 1; pg. 41, 33 pgs.

GRAHAM, John R. Taxes and Corporate Finance. Review of Financial Studies. 16:4 (2003)

GUENTHER, David A. Earnings management in response to corporate tax rate changes: evidence from 1986 Tax Reform Act. The Accounting Review. Jan 1994; 69, 1; ABI/INFORM Global, p. 230-243.

GUENTHER, David A. The relation between tax rates and pre-tax returns: direct evidence from the 1981 and 1986 tax rate reductions. Journal of Accounting and Economics, v. 18, p. $379-393,1994$.

HAMILTON, J. D. Time series analysis. Princeton: Princeton University Press, 1994. 
HARFUCH, Leila. Determinantes da taxa de juros nominal e sua relação com a taxa de câmbio no Brasil no período de 1990 a 2006. Piracicaba, 2008. Tese (Doutorado em Economia) - Escola Superior de Agricultura "Luiz de Queiroz". Universidade de São Paulo.

HAYN, C. Tax attributes as determinants of shareholder gains in corporate acquisitions. Journal of Financial Economics. (June), p. 121-153, 1989.

HENNING, Steven L.; SHAW, Wayne H.; STOCK, Toby. The effect of taxes on acquisition price and transaction structure. The Journal of the American Taxation Association; 2000; 22, ABI/INFORM Global, p. 1-17.

INTERNATIONAL MONETARY FUND. Global Financial Stability Report. Washington DC, April 2007.

Investidor estrangeiro troca dívida externa por dívida interna. G1. 31/01/2007.

Isenção para estrangeiros. Diário da Manhã. Goiás, 17/02/2006.

KNOLL, Michael S. Compaq redux: implicit taxes and the question of pre-tax profit. University of Pennsylvania Law School, paper 134, 2006.

MAYDEW, Edward L. Discussion of the effects of goodwill tax deductions on the market for corporate acquisitions. The Journal of the American Taxation Association. 2000; 22, ABI/INFORM Global, p. 51-53.

MAYDEW, Edward L. Empirical tax research in accounting: A discussion. Journal of Accounting and Economics. v.31, p. 389-403, 2001.

MORETTIN, Pedro A.; TOLOI, Clélia M.C. Análise de séries temporais. 2. ed rev. e ampl. São Paulo: Edgard Blucher, 2006.

Novo papel de longo prazo atrai investidor via internet. Folha de São Paulo. 31/07/2006.

SCHOLES, Myron S. et al. Taxes and business strategy: a planning approach. 3rd ed. New Jersey: Pearson Education, Inc., 2005.

SCHOLES, Myron S. The market for securities: substitution versus price pressure and the effects of information on share prices. The Journal of Business (pre-1986); Apr 1972; 45, 2; ABI/INFORM Global, p. 179-213.

SHACKELFORD Douglas A.; SHEVLIN, Terry. Empirical Tax Research in Accounting. Journal of Accounting and Economics, v. 31, Issue 1-3 (September), p. 321-387, 2001.

SHACKELFORD, Douglas A. The market for tax benefits : evidence from leveraged ESOPs. Journal of Accounting and Economics, v. 14, issue 2, June/1991. 
SINDICATO NACIONAL DOS AUDITORES-FISCAIS DA RECEITA FEDERAL DO BRASIL. MP 281 poderá ser um incentivo para evasão e elisão fiscal e ainda para legalizar dinheiro obtido de forma lícita.

$<$ http://www.forumfbo.org.br/media/isencaoestrangeiros.doc $>$. Acesso em: 19/2/2007.

VANDAELE, Walter. Applied time series and Box-Jenkins models. London: Academic Press, 1983.

VASCONCELLOS, Antonio S.; ALVES, Denisard (editores). Manual de Econometria: nível intermediário. São Paulo: Atlas, 2000.

WILKIE, Patrick J. Empirical evidence of implicit taxes in the corporate sector. The Journal of the American Taxation Association. Sarasota: Spring 1992. Vol. 14, Iss. 1; pg. 97.

WOOLDRIDGE, Jeffrey M. Introdução à econometria: uma abordagem moderna. São Paulo: Pioneira Thomson Learning, 2006. 